\title{
Characterization and quality of soils developing on a mountaintop removal coal mine
}

\author{
Kevin Alfred Thomas \\ West Virginia University
}

Follow this and additional works at: https://researchrepository.wvu.edu/etd

\section{Recommended Citation}

Thomas, Kevin Alfred, "Characterization and quality of soils developing on a mountaintop removal coal mine" (2001). Graduate Theses, Dissertations, and Problem Reports. 1320.

https://researchrepository.wvu.edu/etd/1320

This Thesis is protected by copyright and/or related rights. It has been brought to you by the The Research Repository @ WVU with permission from the rights-holder(s). You are free to use this Thesis in any way that is permitted by the copyright and related rights legislation that applies to your use. For other uses you must obtain permission from the rights-holder(s) directly, unless additional rights are indicated by a Creative Commons license in the record and/ or on the work itself. This Thesis has been accepted for inclusion in WVU Graduate Theses, Dissertations, and Problem Reports collection by an authorized administrator of The Research Repository @ WVU. For more information, please contact researchrepository@mail.wvu.edu. 
Characterization and Quality of Soils Developing on a Mountaintop Removal Coal Mine

Kevin A. Thomas

Thesis submitted to The College of Agriculture, Forestry, and Consumer Sciences at West Virginia University

In partial fulfillment of the requirements for the degree of

\author{
Masters of Science \\ In \\ Plant and Soil Sciences
}

\author{
John C. Sencindiver, Ph.D., Chair \\ Jeffrey Skousen, Ph.D. \\ Paul Ziemkiewicz, Ph.D. \\ Steve Kite, Ph.D.
}

Division of Plant and Soil Sciences

Morgantown, West Virginia

2001

Keywords: characterization, quality, soils, mountaintop removal coal mine 


\begin{abstract}
Characterization and Quality of Soils Developing on a Mountaintop Removal Coal Mine
\end{abstract}

\title{
Kevin Thomas
}

Mountaintop surface mining for coal has been practiced in West Virginia for over three decades, but its environmental impacts have become increasingly scrutinized in recent years. Therefore, this study evaluated soil development on different aged mined lands. Four different ages $(2,7,11$, and 23 years) of minesoils and two different slope classes, nearly level to gently sloping and steep to very steep, along with three contiguous native soils on a reclaimed mountaintop removal mine in Logan County, West Virginia were described and sampled. Standard analyses of physical and chemical properties were conducted in order to classify these soils. Some of the data also were used to test a productivity index for Appalachian minesoils. Physical analyses of these soils revealed the minesoils are developing with age, indicated by increasing A horizon thickness, solum thickness, and increased aggregate stability with time. Chemical analyses showed higher $\mathrm{N}$ with minesoil age. Minesoils had higher bases, $\mathrm{pH}$, and base saturation than native soils, but native soils had higher carbon, nitrogen, aluminum, and manganese. Current accepted soil classification names give little information on the unique properties of these minesoils, but three proposed modifications to Soil Taxonomy reveal more useful knowledge. The calculated productivity index showed the minesoils as a group to be less productive than native soils, but the older minesoils were similar to the native soils. 


\section{Acknowledgments}

First and foremost I would like to thank my lovely wife Adrienne Thomas. Without her patience, tolerance, and support, no matter my temperament, this endeavor would not have been possible. To my daughter Emma, I say thank you for the carefree perspective and heart felt feelings of joy you gave me everyday I thought I could no longer continue to deal with the everyday frustrations of life.

To my mother Brenda Thomas and stepfather Bobby Bridwell who no matter what direction I took in life you never gave me less than 100\% support. I would like to thank my grandfather Easly Brock who instilled in me the most valuable lesson of life I have ever been taught: To give back to the earth what she has so freely given to us. To my late grandmother Mary Brock who supported me through the thick and thin, and never turned her back on me no matter what action or course I took in life.

To my advisor Dr. John Sencindiver, who took a leap of faith with me, I thank you for the guidance and support given so freely from you. Your door was always open to me, whether in good times or bad.

I would like to thank Dr. Skousen for his support and patience with me. I would also like to thank Dr. Kite and Dr. Ziemkiewicz for taking time to aid in guiding me as committee members.

Last, but not least a special thanks to all the workers, and friends who supported me and never let me quit. 


\section{Table of Contents}

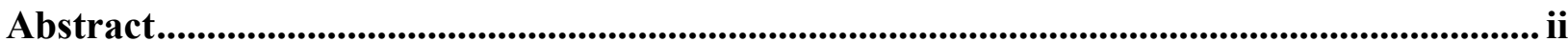

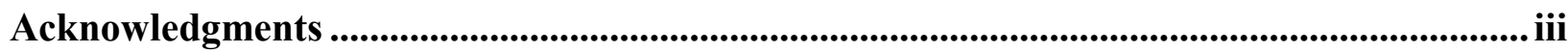

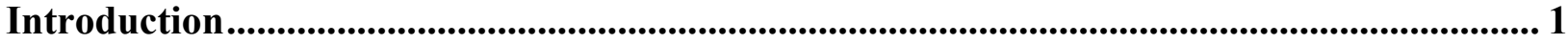

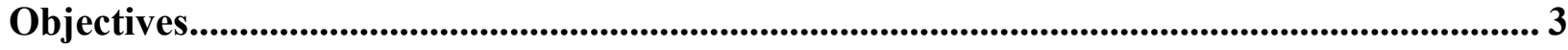

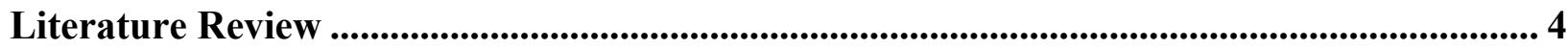

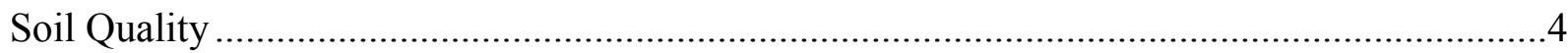

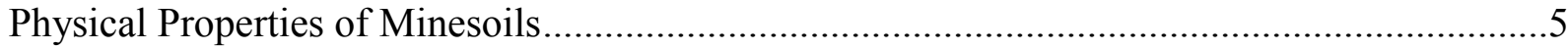

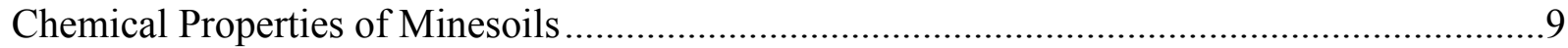

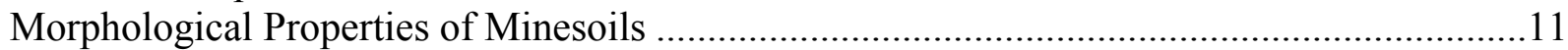

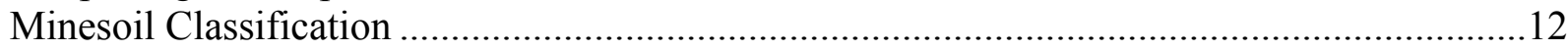

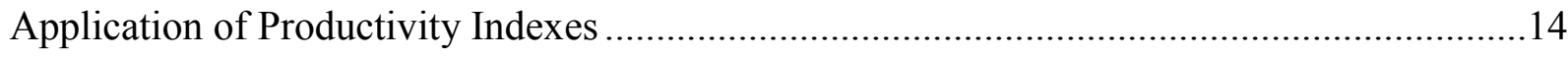

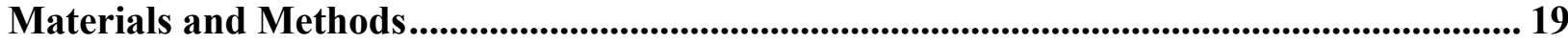

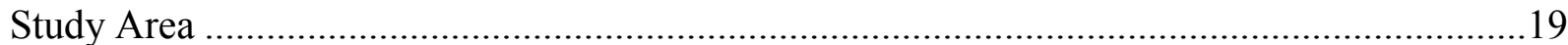

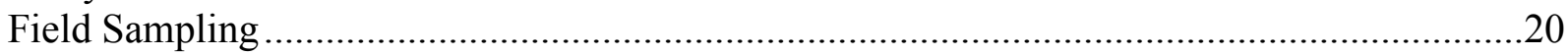

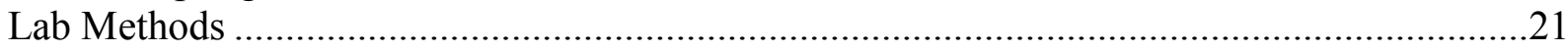

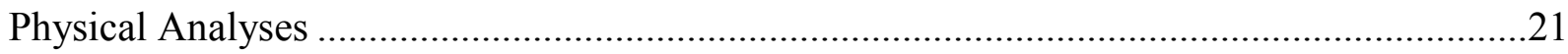

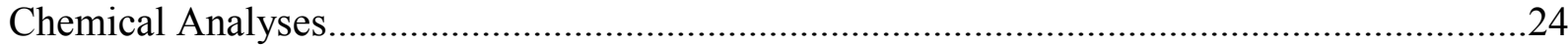

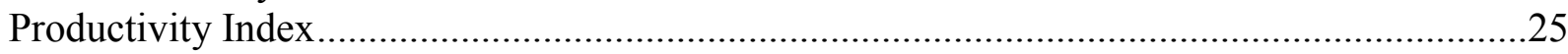

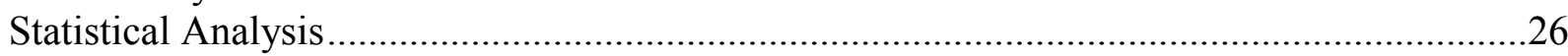

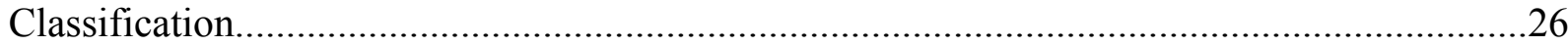

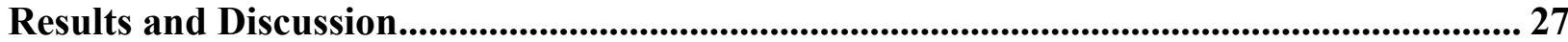

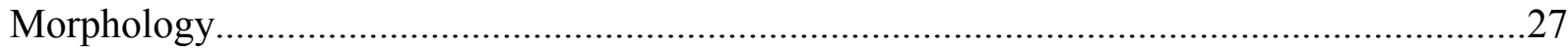

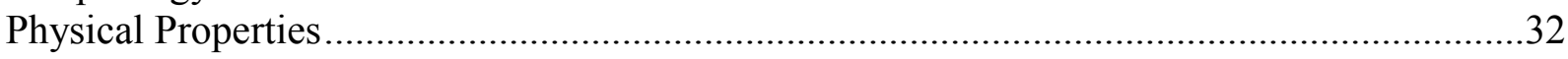

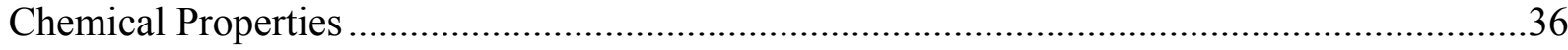

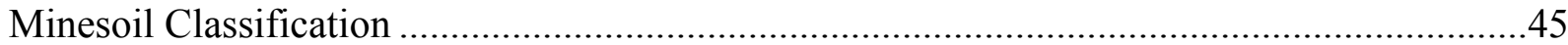

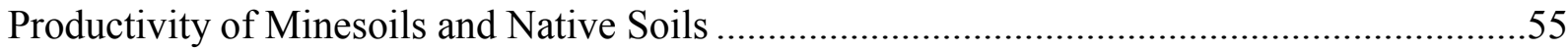

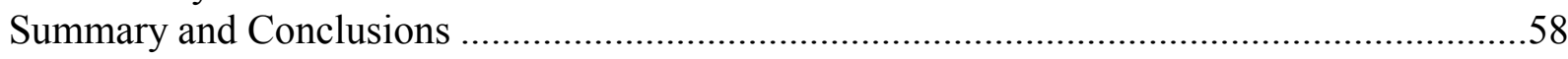

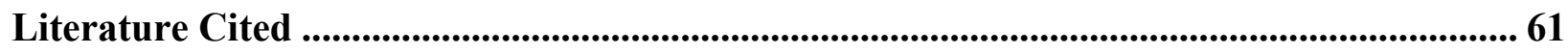

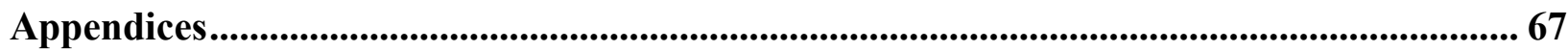

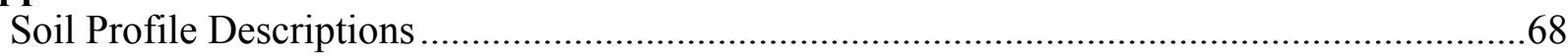

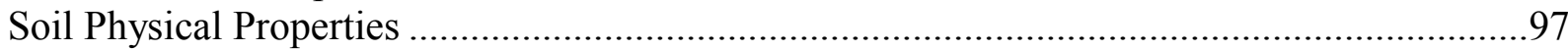

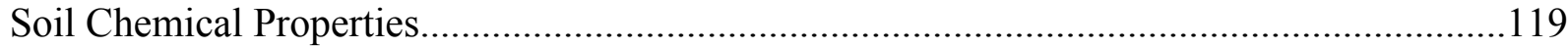

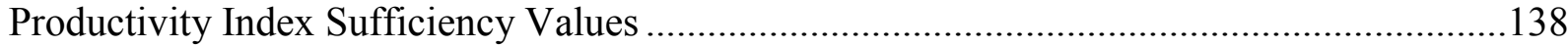

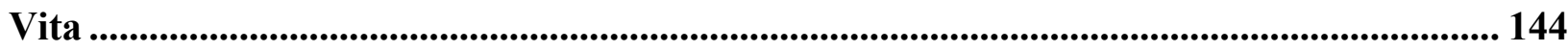




\section{Introduction}

Moutaintop removal mining (MTM) has been practiced for over three decades in West Virginia and other regions of the central Appalachian coal fields of the eastern United States. The practice has become increasingly scrutinized by the public and regulatory agencies. Increased attention has focused on the environmental impacts of this mining process.

The process of MTM results in reclaimed landscapes that always differ from the original landscapes. The mining process adapts the concepts of area mining for use in steeply sloping terrain. As a result, relief is generally reduced to that of the lowest economically mineable coal seam and the spoil is commonly placed in head-of-hollow or valley fills.

Since the reclaimed landscapes are less steep than the original landscapes, often consisting of some flat or gently rolling topography along with steep outslopes, many landowners have desired pasture or hayland as the post-mining land use. Therefore, grasses and legumes are seeded to meet this desired post-mining land use. The coal operators often prefer this revegetation strategy because the extensive forage growth controls erosion quickly, is aesthetically pleasing and is relatively inexpensive to establish. Wildlife habitat, which is sometimes the designated post-mining land use, is accomplished by seeding the same grasses and legumes, with tree seeds added to the seed mix.

Many of these reclaimed lands seeded to grasses and legumes have not been properly managed or maintained as pasture lands. Therefore, many of these sites have reverted to shrub and forestland. This change in land use has partially led to environmental concerns relating to soil quality, productivity and future land use. Recent concerns expressed by environmental groups have led regulators to revisit post-mining land use designations. As a result, greater emphasis is now being placed on commercial forestry and a new post-mining land use called homesteading. 
Soils developing on these mined and filled areas differ from the original soil, but they have not been widely evaluated. Few studies on soil quality and development on MTM sites have been performed, and little information is known about long-term environmental changes on these sites. Soil development and quality on these sites is important and research can provide information about their long-term potential to produce productive commercial forest and their ability to promote the development of diverse and stable plant communities for alternative land uses. 


\section{Objectives}

1. To describe and characterize different aged minesoils on a reclaimed MTM coal mine, and contiguous native soils

2. To evaluate minesoil development by comparing different aged minesoils to each other and to native soils

3. To classify minesoils by accepted or proposed methods

4. To evaluate potential forest productivity and minesoil quality by using a published productivity index. 


\section{Literature Review}

\section{Soil Quality}

Interest in soil quality worldwide has been stimulated by renewed awareness that soil is vital to both plant production and ecosystem function. Soil quality can be broadly defined as the capacity of a living soil to function within natural or managed ecosystem boundaries, to sustain plant and animal productivity, maintain or enhance water and air quality, and promote plant and animal health (Doran et al., 1999). A common accepted working definition of soil quality is based on its capacity to perform productivity, environmental, and health functions. The relationship of soil quality to soil productivity is probably the best understood of the soil quality components (Bezdicek et al., 1996). Less is understood on the relation of soil quality to environmental quality. However, many soil quality parameters favorable to plant productivity can enhance environmental quality (Bezdicek et al., 1996).

Currently, soil degradation is a major concern because of adverse impacts on a local, regional, and global scale. Consequently, there have been several attempts to assess soil degradation by: (1) relating the severity of soil degradation to productivity under improved or science-based management and inputs; (2) determining the relationship of soil properties and processes to soil quality as determined by its life support processes and environmental regulatory functions; and (3) knowing soil's resilience capacity to restore itself (Doran et al., 1999). The term resilience is new to soil science. It has been defined as the ability of a soil to resist adverse changes under a given set of ecological and land use conditions, and to return to its original dynamic equilibrium after disturbance (Doran et al., 1999).

There are several soil property factors affecting soil resilience including soil water retention and transmission properties, cation exchange capacity, soil organic matter, soil 
structure, and soil pH (Doran et al., 1999). Karlen et al. (1997) selected 10 soil parameters that used soil physical, chemical, and biological properties as an approach to evaluate soil quality. These parameters were: (1) organic matter, (2) infiltration, (3) aggregation, (4) $\mathrm{pH}$, (5) microbial biomass, (6) forms of Nitrogen, (7) bulk density, (8) topsoil depth, (9) conductivity, and (10) available nutrients. Many of these properties or parameters have been addressed in the following minesoil studies.

\section{Physical Properties of Minesoils}

The physical condition of a soil has a direct and indirect effect on environmental quality (Doran and Parkin, 1996). Minesoils are very young soils developing from mixtures of fragmented rock and fine-earth material. The original soil profiles have been disrupted and are often partially or totally replaced by earth materials from depths below the original profile. Studies have shown that upon exposure to the surface environment, accelerated weathering may occur and increase soil development (Ciolkosz et al., 1985; Johnson and Skousen,1995). This development has been linked to human influences as well as natural processes (Hoover, 1994; Indorante and Jansen, 1984; Schroer, 1978; Smith and Sobek, 1978). Accelerated physical weathering of rocks caused by blasting and movement during both mining and reclamation, and the addition of organic materials during reclamation increase the rate of soil development (Sencindiver and Ammons, 2000). One of the first characteristics noticed about a minesoil is the amount of rock fragments that can be found at most sites. In a study on early stages of minesoil genesis in a southwest Virginia spoil lithosequence, Roberts et al. (1988b) found that rock fragments ranged between $65-70 \%$ of the minesoil volume. Johnson and Skousen (1995) reported rock fragments ranging from $37-67 \%$ on 15 abandoned mine land sites in West 
Virginia. As a result of such a high rock fragment content, large voids are usually found within the minesoil. These voids form due to overlapping rock fragments and do not allow all spaces to be filled with fine-earth material during the backfilling process. Ammons (1979) and Ammons and Sencindiver (1990) noted that these voids might improve aeration and reduce water holding capacity in some minesoils, but could enhance plant available water by providing small reservoirs of low tension water in other minesoils.

Schafer et al. (1980) discovered that rock fragments found near the surface of a Montana minesoil weathered quickly to soil material. In general, it has been noted that rock fragment content of the surface horizons decreased with time as rock fragments slaked and weathered (Hearing, et al. 1993; Hoover, 1994; Roberts, et al. 1988a). Ciolkosz et al. (1985) and Sencindiver (1977) reported that surface layers of most minesoils have smaller amounts of rock fragments than deeper horizons. They attributed this phenomenon to more active chemical and physical weathering at the surface.

Another trend noted by Roberts et al. (1988a) is that minesoils tend to be very droughty. They related the droughtiness to high rock fragment content. It has been demonstrated that minesoils retain less water than natural soils (Pederson et al., 1980; Thurman and Sencindiver, 1986; Younos and Shanholtz, 1980). The decreased retention of water in minesoils can be associated with the destruction of the soil pores and an increase in rock fragment content throughout the soil profile. Minesoil plant available moisture is sometimes less than that found in adjacent native soils (Pederson et al., 1980; Silburn and Crow, 1984) and may be inadequate for productive plant growth during short drought periods (Plass and Vogel, 1973).

Bulk density tends to be higher in minesoils than in adjacent native soils (Roberts et al., 1988b; Sencindiver and Ammons, 2000; Strain and Evans, 1994; Thurman and Sencindiver 
1986). However, Schafer et al. (1980) found that bulk density of old minesoils was equal to or less than the native soil, but young minesoils had slightly higher bulk densities. Schafer et al. (1980) also indicated that the higher densities were likely due to the high sand content from the parent material and the equipment used for reclamation rather than pedogenic processes. The concept of higher bulk densities as related to equipment used, or grading technique also was noted by Johnson (1992), who studied natural reclamation of abandoned mine lands in West Virginia. Bell et al. (1994) indicated a relationship between rock fragment content and bulk density. Their Pennsylvania minesoils had lower bulk densities where ever voids or compaction was hindered due to high rock fragment content. However, where the rock fragment content was lower, the amount of void space was decreased and compaction was increased. Sencindiver and Ammons (2000) and Varela et al. (1993) indicated that lower bulk density found in the surface horizons of minesoils has been attributed to biological activity, organic matter incorporation, root penetration, and/or freeze-thaw cycles. In relation to minesoil quality, a study on Illinois minesoil found that soil compaction limited row crop production (Dunkard et al., 1992).

Higher bulk densities or compaction will affect water movement, aeration, and plant root extension. Daniels and Amos (1979) noted very dense $\left(1.8 \mathrm{~g} / \mathrm{cm}^{3}\right)$ traffic pans were found within $70 \mathrm{~cm}$ of the soil surface of minesoils in Wise County, Virginia. They concluded that compacted layers had seriously curtailed soil development in more than half of the minesoils they studied. These layers restricted downward movement of water, air and plant roots. The layers also tended to perch water and cause wet spots in normally well drained positions.

Structure refers to aggregation of individual particles into larger units with planes of weakness between them. Most minesoils, even those that are young, tend to have some weak to moderate structure that has developed in their surface horizons. The structure is primarily 
granular or subangular blocky (Hoover, 1994; Roberts et al., 1988b). However, platy structure has been reported by McSweeney and Jansen (1984). This platy structure often results from machinery compaction during minesoil construction. Most minesoils are massive, meaning the mineral grains are bound together into one mass having only a few desiccation cracks. This structureless material is often associated with heavy traffic and large equipment moving over the newly deposited material. McSweeney and Jansen (1984) noted that earth-moving operations carried out during surface mining resulted in considerable alteration of the structure of premine soils. The resulting minesoils typically exhibited a physical condition dominated by features attributed to the soil construction operation, rather than from influence of natural soil forming factors. McSweeny and Jansen (1984) described a new type of structure, which they called "fritted". They associated this new structure to the bucket-wheel excavation method were the overburden or soil was transported on a conveyor belt. The structure had an appearance similar to semifused spheres and consisted of rounded aggregates loosely compressed together. A study of root growth and the newly classified fritted structure found that root development in a fritted soil pit was much more extensive than in a pit exhibiting a massive condition, or two other pits with massive and fritted structure.

Aggregate stability refers to the ability of soil aggregates to resist disruption when outside forces are applied. The degree and stability of aggregation in minesoils affects numerous soil properties including water movement, aeration, heat transfer, erodibility, available water holding capacity, soil tilth, and productivity of mined lands (Limstrom, 1960; Omodt et al., 1975). When comparing native or undisturbed soils to minesoils, the degree of aggregation and the percentage of water stable aggregates on many minesoils are generally lower than that of the native soils (Cole, 1976; Wilson 1957). Cole (1976) reported that water stable aggregates on 
minesoils had less clay than the total soil fraction, indicating that something other than clay may be serving as the binding agent for minesoil aggregates. Gorman et al. (1991) address the idea of an alternate binding agent, other than clay. They suggested that calcium carbonate was acting as the aggregating agent in their study of physical properties of fly ash-treated minesoils. In the same study, but a different type of fly ash, with lower Ca content, the authors concluded that organic contributions might have been playing the role of a binding agent. Wilson (1957) compared aggregation on minesoils under numerous vegetation types, including grass/legume, tree, barren or no cover. Wilson discovered that the degree and stability of aggregation was best under the grass/legume cover, and worst on the barren soil.

Minesoil textures often vary irregularly with depth as a result of stratification during the reclamation process (Pederson et al., 1978). However, some researchers have shown that some minesoils show little variation in texture within pits or between pits in a single mined area (Ciolkosz et al., 1985; Hoover, 1994).

\section{Chemical Properties of Minesoils}

Minesoil chemical properties are site specific. These properties usually reflect characteristics of the overburden and reclamation practices of the given area. Minesoil properties are closer to their parent material properties than natural soil are to their parent material properties (Sobek et al., 1978). Natural soils have had greater time to weather and develop their own unique set of properties based on climate, aspect, and organisms.

Minesoils usually have lower organic matter contents than adjacent native soils, and irregular distribution of organic carbon with depth. This irregular distribution can be associated with coal and dark shale fragments found throughout the soil as well as mixing of the original 
soil with depth (Ciolkosz et al., 1985; Pederson et al., 1978; Smith et al., 1971; Thurman and Sencindiver, 1986).

Minesoil $\mathrm{pH}$ values have been known to range from as low as 2.9 to as high as 8.2 (Barnhisel and Massey, 1969; Ciolkosz et al., 1985; Daniels and Amos, 1982; Plass and Vogel, 1973; Sencindiver, 1977; Smith et al., 1971; Skousen et al., 1998). At low pH, certain elements such as $\mathrm{Al}$ and $\mathrm{Mn}$ become toxic to plants and may contribute to vegetation failures on minesoils (Berg and Vogel, 1968; Berg and Vogel, 1973; Fleming et al., 1974). Concentrations of Fe, $\mathrm{Cu}$, $\mathrm{Zn}$, and Ni may also be toxic to plants, and they are most likely to occur where plant-toxic Al and Mn are present (Massey, 1972; Massey and Barnhisel, 1972). In some cases minesoil pH values have been reported as being equal to the contiguous native soils (Pederson et al., 1978; Thurman and Sencindiver, 1986). In general it has been noted that minesoil $\mathrm{pH}$ is influenced by human interactions, such as liming and the placing of alkaline material on the surface during reclamation, and natural interactions, such as leaching caused by rainfall.

Ciolkosz et al. (1985) found the majority of acid minesoils in Pennsylvania to have Electrical Conductivity values of $4 \mathrm{dS} / \mathrm{m}$ or higher in all or part of the profile. These high values were attributed to gypsum and other sulfate salts of $\mathrm{Na}, \mathrm{Mg}, \mathrm{Al}$, and $\mathrm{Mn}$. In general the concentration of these salts increased with depth and exceeded toxic levels. These high EC values will restrict the yields of most plants.

Phosphorus and nitrogen deficiencies in minesoils are widely recognized in minesoils throughout the eastern coal region (Barnhisel and Massey, 1969; Daniels and Amos, 1981; Smith and Sobek, 1978). In areas of the eastern coal region where acidic minesoils occur, phosphorus and water have been reported as being the most common limiting factors of obtaining adequate vegetation cover (Barnhisel, 1977). 
Exchangeable bases in minesoils often reflect the base status of the original pre-mine native soil or overburden strata. Base saturation may vary in minesoils from 1 to $100 \%$ (Ciolkosz et al., 1985; Daniels and Amos, 1982; Short et al., 1986a; Smith et al., 1971). However, it has been noted that base saturation may be improved by mixing rock of high base status with the original soil (Pederson et al., 1978; Smith et al., 1971). Deep leaching of bases has been observed in acid minesoils as the soil's age increased (Down, 1975; Johnson and Skousen, 1995; Rich and Obenshain, 1955; Singh et al., 1982).

\section{Morphological Properties of Minesoils}

Natural soils and minesoils have distinctly different morphological features. All soils exhibit properties that are a function of time, topography, parent material, organisms, and climate. However, minesoils do not show the effects of these five factors as much as natural soils because of shortness of time. Therefore, most mine soils have A-C or A-AC-C profiles with an ochric epipedon.

Within a short time frame, such as three years, most minesoils develop A horizons, as noted by several studies (Ciolkosz et al., 1985; Daniels and Amos 1981; Haering et al. 1993; Schafer 1980; Sencindiver and Ammons, 2000; Thomas et al., 1999; Thurman and Sencindiver 1986). Daniels and Amos (1981) attributed the development of A horizons to loose sandstone spoil materials and vigorous plant growth. Physical and chemical weathering also play a role in breaking down rock fragments very rapidly in near-surface environments, so A horizons typically have lower rock fragment contents than subsurface horizons. Daniels and Amos (1981) described distinct B-horizons with strong structural aggregation in minesoils that were as young 
as 19 years old. Thus, it is evident that pedogenesis does occur in minesoils in a relatively short time.

Ciolkosz et al. (1985) showed a general trend of increasing soil horizon development with time. Their data indicated it took approximately 3 to 13 years to form an A horizon, 6 to 20 years to form an A-AC sequence, and 12-28 years to form an A-B sequence. Their data also showed that a 30-year-old minesoil had developed at approximately $1.6 \mathrm{~cm} / \mathrm{yr}$.

Roberts et al. (1988a) described weak A horizons within three years, but described no divisions of the $\mathrm{C}$ horizon below the A horizon. However, profiles were examined two years later, and all four soils had A-C1-C2 sequences. Roberts et al. (1988a) attributed this sequence to weak patchy structural development in the $\mathrm{C} 1$ horizon, and large rock fragments in the $\mathrm{C} 2$ horizon.

\section{Minesoil Classification}

Soil, as defined by the Soil Survey Staff (1998), is a natural body comprised of solids (mineral and organic matter), liquid, and gases that occurs on the land surface, occupies space, and is characterized by one or both of the following: horizons, or layers, that are distinguishable from the initial material as a result of additions, losses, transfers, and transformations of energy and matter or the ability to support rooted plants in a natural environment.

U.S. soil classification probably had its beginnings in 1864 when Eugene wrote "the census report" and divided soils by color and carbonate content (Cline, 1977). Almost 100 hundred years later, in 1975, the first edition of Soil Taxonomy was published (Soil Survey Staff, 1975). The nomenclature used was hierarchical including order, suborder, great group, subgroup, family, and series. Since the first publication of Soil Taxonomy, many changes have been made. 
Twenty-four years after the first edition, the second edition was published in 1999 (Soil Survey Staff, 1999).

One issue, which is now being evaluated, is the need for Soil Taxonomy to better accommodate minesoils (ICOMANTH, 1995). As mentioned earlier, most minesoils have an AC or A-AC-C horizon sequence with ochric epipedons (Ciolkosz et al., 1985; Schafer, 1979; Sencindiver, 1977; Short et al., 1986a). As a result, these soils would be classified as Entisols. As time progresses, Bw horizons will form in many of these minesoils, and some will meet the cambic criteria (Ciolkosz et al., 1985; Short et al., 1986b). These minesoils would be classified as Inceptisols. Most of the minesoils are classified as Orthents simply because they do not fit in any other defined suborder (Schafer, 1979b; Short et al., 1986a; Sencindiver, 1977). As a result, researchers at West Virginia University (Ammons and Sencindiver, 1990; Sencindiver, 1977; Sencindiver et al., 1978; Thurman and Sencindiver, 1986) proposed a new suborder, Spolents, for minesoils they studied primarily in West Virginia, but also including other eastern and midwestern states. Their research indicated that minesoils have at least three of the following properties:

1. Disordered rock fragments.

2. Color mottling not associated with horizonation or redoximorphic features.

3. Splintered edges on rock fragments.

4. Bridging voids between rock fragments.

5. A thin surface horizon generally higher in fines than any other horizon.

6. Local pockets of dissimilar material, but parts of former diagnostic horizons.

7. Artifacts.

8. Carbolithic (black, high carbon) rock fragments. 
9. Irregular distribution of oxidizable carbon with depth.

The great group Udispolent, and nine subgroups were proposed using the nine properties previously listed. The system was not accepted for incorporation into Soil Taxonomy, but was used to develop mapping units for minesoils in some state soil surveys.

This proposed system is not the only one to suggest revisions to Soil Taxonomy. Fanning and Fanning (1989) proposed revisions to the definition of Typic Udorthents and proposed new subgroups for scalped land surfaces (Scalpic), locally derived fill materials that have been moved by earth-moving equipment and have few or no manufactured inorganic artifacts (Spolic), miscellaneous urban fill materials that contain inorganic manufactured artifacts (Urbic), and organic wastes of human activity (Spolic Garbic or Urbic Garbic). Strain and Evans (1994) used Fanning and Fanning (1989) concepts of spolic, urbic, or garbic materials and of scalped land surfaces for sand-and-gravel-pit soils and proposed Anthrosols, a new soil order that they expanded from an original proposal of Kosse (1988).

\section{Application of Productivity Indexes}

A relatively new approach for modeling site productivity is the use of a Productivity Index (PI). Productivity models convert soil data into estimates of crop productivity based upon the depth and quality of the soil (Torbert et al., 1994). The Chinese have been credited with using the first productivity index 40 centuries ago. One of the first productivity indices ever developed in the United States was by Kiniry et al. (1983) for agricultural soils (Equation 1).

$\mathrm{PI}=(\mathrm{A} \times \mathrm{B} \times \mathrm{C} \times \mathrm{D} \times \mathrm{E}) \times \mathrm{WF}$

Where:

$\mathrm{PI}=$ Productivity index

$A=$ sufficiency of potential available water storage capacity 
$\mathrm{B}=$ sufficiency of aeration

$\mathrm{C}=$ sufficiency of bulk density

$\mathrm{D}=$ sufficiency of $\mathrm{pH}$

$\mathrm{E}=$ sufficiency of electrical conductivity

$\mathrm{WF}=\mathrm{a}$ weighting factor based on soil depth

The authors' approach was derived from Storie (1933), who related productivity to soil properties. However, the approach by Kiniry et al. differed in the fact that they attempted to describe root growth first and then related it to productivity. Their main assumption upon which the PI model was developed was that soils that provide an ideal rooting environment will allow maximum crop growth. The calculated PI reflects a soil's potential for root growth with the assumption that optimum conditions for root growth will result in the highest aboveground yield (Kiniry et al., 1983). A PI of 1.0 might represent ideal conditions and maximum possible yield for a given climate. For a corn crop, a PI of 1.0 might represent a yield of 200 bushels per acre. For white pine, a PI of 1.0 would represent a site index at 50 years of 100-110 (Torbert et al., 1994).

One of the first aspects of deriving a PI model is to understand which soil variables affect tree growth. The first step is to assign sufficiency values for each of these variables. These values are normalized between 0.0 and 1.0, and quantify the influence of each property on tree growth (Torbert et al., 1994). If a value of 0.0 is assigned to any soil property, then it is recognized that this variable will totally inhibit tree growth. Where a value of 1.0 is assigned, then this value would represent no impeded tree growth. A more realistic value, such as 0.60 , would indicate that potential tree growth will be $60 \%$ of the optimum growth.

Earlier PI models combined individual sufficiency values multiplicatvely to get an overall soil sufficiency (Gale 1987). One disadvantage presented by Gale (1987) was that the overall rating for soil could be considerably lower than the sufficiency rating for the most 
limiting soil property within that soil. For instance, a three-factor model might have factor ratings of 0.90 for each sufficiency, but the overall rating would only be $0.73(.9$ x.9 x .9). Therefore, Gale (1987) used the geometric mean of the individual rating to arrive at a horizon rating. The geometric mean gives equal weight to proportional differences in factor ratings and not to absolute differences as in Gale's original model. Thus, if all factors were 0.90 , the multiplicative rating would be 0.90 (Equation 2).

$$
P I=\left((0.9 \times 0.9 \times 0.9)^{1 / 3}\right)
$$

Gale et al. (1991) developed equation 3 for predicting forest productivity on unmined soils. In this equation, A was the sufficiency for potential available water, B sufficiency for aeration, $\mathrm{C}$ the sufficiency for bulk density, $\mathrm{D}$ the sufficiency for $\mathrm{pH}$, SI the sufficiency for percent slope, and CI the sufficiency for climate. The weighting factor (WF) was based on a curve developed by Gale and Grigal (1987) for midtolerant tree species. Burger et al. (1994) modified Gale's equation for forest productivity on mined lands in south western Virginia and southern West Virginia in equation 4, where EC equals electrical conductivity of the soil, $\mathrm{P}$ is soil phosphorus, BD equals the bulk density, WF equals the weighting factor developed by Gale and Grigal, and SI equals slope.

$$
\begin{aligned}
& P I=\sum_{i=1}^{r}\left([A x B x C x D]_{i}^{1 / 4} x W F\right) x[S I x C I]^{1 / 2} \\
& P I=\sum_{i=1}^{r}\left([p H x E C x P x B D]^{1 / 4} x W F\right)_{i} x[S I]
\end{aligned}
$$


The weighting factor (WF) was developed by Gale and Grigal (1987) from the following equation (5):

$$
Y=1-B^{d}
$$

where $\mathrm{Y}$ is the cumulative root fraction from the surface to soil depth (d) in centimeters, and B is a mean root distribution coefficient developed for tolerance classes of trees by Gale and Grigal (1987). Torbert et al. (1994) used white pine, which is a midtolerant species with a B value of 0.96. Therefore, $Y=1-(0.96)^{\mathrm{d}}$, and the value $\mathrm{Y}$ becomes the WF in equation 4 . As an example: a soil that is $45 \mathrm{~cm}$ deep with two horizons would have two weighting factors, one per horizon. The first horizon is $10 \mathrm{~cm}$ thick and the second is $35 \mathrm{~cm}$ thick. First set $\mathrm{Y}=1-(0.96)^{10}$ and then calculate WF, which equals $Y$. Then set $Y=1-(0.96)^{45}$ and calculate Y. However, at this point subtract the second horizon's Y from the first to get a corrected WF. Also we assume the soil has a $\mathrm{pH}, \mathrm{P}$, and slope value considered to be ideal for tree growth. Productivity Index:

$\mathrm{PI}=$ Equation (4)

Horizon $1=(1.0 \times 1.0)^{1 / 2} \times\left(1-0.96^{10}\right)$

$=1.00 \times 0.335$

$=0.335$

Horizon $2=(1.0 \times 1.0)^{1 / 2} \times\left(1-0.96^{45}\right)$

$=1.00 \times(0.84-0.335)=0.505$

P.I. $=(0.335+0.505) \times 1.00=0.84 \times 100=84.0 \%$

This means that the soil would be able to produce a white pine yield that is $84.0 \%$ of the maximum obtainable for the climate.

One problem faced by using a PI is that the sufficiency relationship for each soil variable may not be well defined. In theory, sufficiency relationships are based on the effect of soil properties on root growth. However, few studies have been conducted to evaluate the 
relationship between variables such as electrical conductivity or $\mathrm{pH}$ on root growth. In reality, sufficiency relationships tend to be based on relationships between soil properties and aboveground plant growth (Torbert et al., (1994).

Previous research by Gale et al. (1991) has shown that as a measure of site quality the PI performs better in younger stands than older. It is a better index of site quality in younger stands because it uses the effects of soil characteristics on vertical root distribution. The PI model is based on mineral soil characteristics and is more applicable in younger stands that have not accumulated thick organic layers. As stands mature, a litter layer accumulates, which seems to shift the rooting habits of the tree from extracting nutrients from the mineral soil to an increased emphasis on nutrients in the forest floor (Wells and Jorgensen, 1975).

However, it appears that a PI model could be useful for mine land reclamation. First, it could be a tool for planning reclamation, and second, it could be used as a means of assessing limiting growth factors to trees during the reclamation bond period. 


\section{Materials and Methods}

\section{Study Area}

In July 1999, minesoil and contiguous native soil pits were dug and samples were collected on a mountaintop removal site near Sharples, Logan County, West Virginia (Fig. 1). The coal beds mined at this site were within the Kanawha Formation, which is composed of approximately 50\% sandstone and 50\% shale, siltstone, and coal: several marine zones may be found throughout the formation (Cardwell et al., 1968). Most of the soils in the unmined area are moderately deep to very deep Dystrudepts or Hapludults, forming in residuum or colluvium. General slope classes of the pre-mined and the mined and reclaimed areas were gently sloping to very steep. However, the general relief of the reclaimed areas is less than the pre-mined landscape.
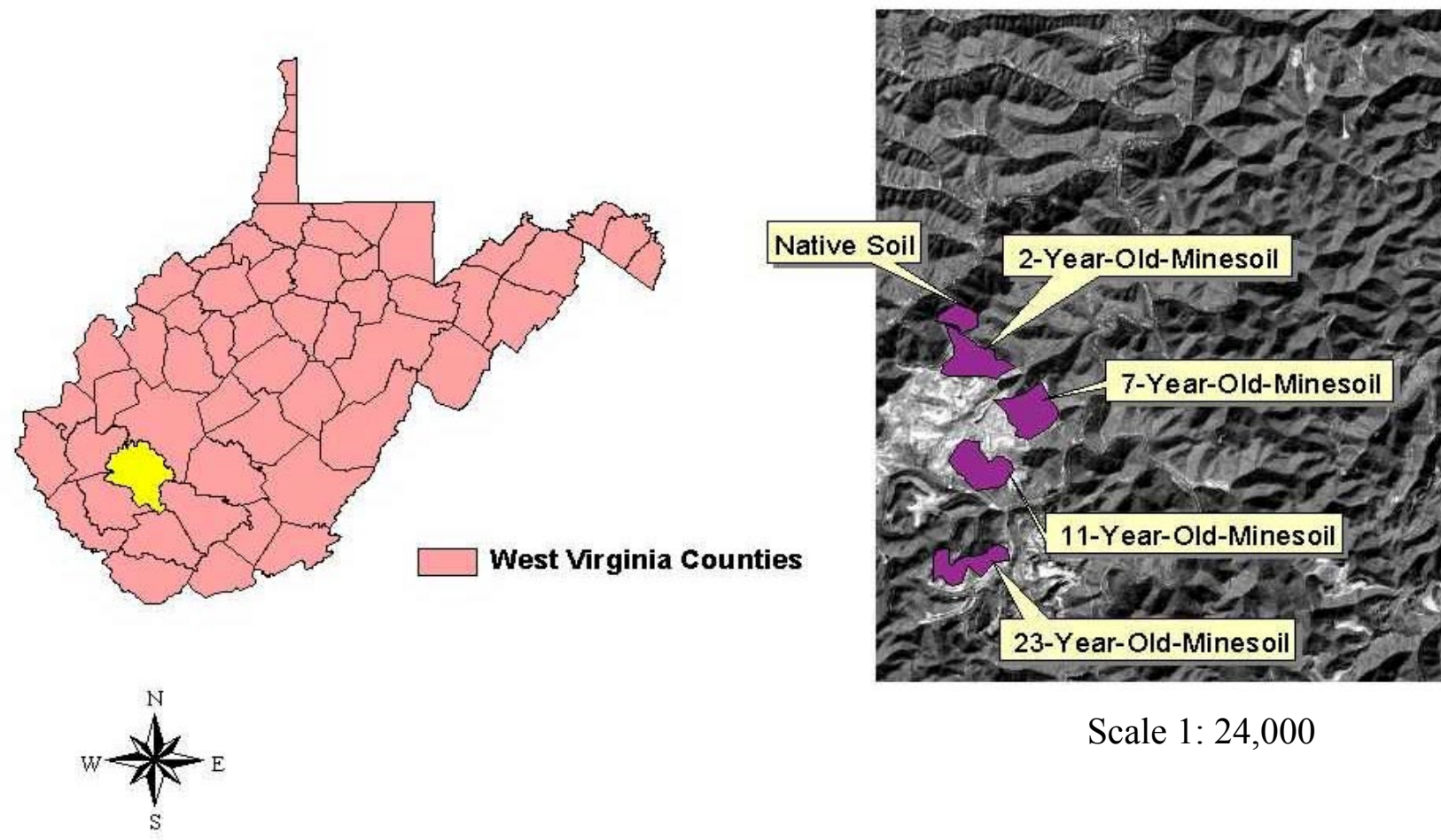

Figure 1. Location map of minesoils and contiguous native soils. 
Elevation of the native landscape where samples were collected ranged from 561 to 568 $\mathrm{m}$ (1845-1863 ft), and the reclaimed mined land elevations ranged from 442 to $525 \mathrm{~m}$ (1450$1720 \mathrm{ft})$. The average air temperature during the summer months is $22.8^{\circ} \mathrm{C}\left(73^{\circ} \mathrm{F}\right)$, and in the winter $1.0^{\circ} \mathrm{C}\left(34^{\circ} \mathrm{F}\right)$ (Wolf, 1994). Annual precipitation is $112 \mathrm{~cm}(44 \mathrm{in}), 55 \%$ of which falls between April and September. The major vegetation before mining was predominantly forest that consisted of; northern red oak (Quercus rubra, L.), black oak (Q. velutina, Lam.), yellow poplar (Liriodendron tulipifera, L.), hickory (Carya sp.), scarlet oak (Q. coccinea, Muench.), white oak (Q. alba, L.) and American beech (Fagus grandifolia, Ehrh.) (Wolf, 1994).

\section{Field Sampling}

Four different ages of reclaimed mined land with two slope classes each were sampled in 1999. These sites had been reclaimed in 1976 (23 yrs), 1988 (11 yrs), 1992 (7 yrs), and 1997 (2 yrs). The slope classes consisted of one that was steep to very steep and a second that was nearly level to gently sloping. Three replications of each of the minesoil slope classes and age combinations were sampled. Soil clods were collected in triplicate from each subsurface horizon, and coated with a saran resin to be analyzed for bulk density by a water-displacement method in the laboratory (Method 4A, 4A1, 4A1a, 4A1h, Soil Survey Staff, 1996). Surface horizons were normally too thin and too friable for clod sampling. Therefore, bulk density of all surface horizons was determined by a frame excavation procedure developed by Dr. Robert Grossman at the USDA-National Soil Survey Laboratory in Lincoln, NE. The details of this method are explained in the following physical analysis section. Vegetation on the 11-year-old minesoils was predominantly grasses, legumes and sparse black locust (Robinia pseudoacacia L.), and the 7-year-old vegetation was a combination of grasses, legumes, and shrubs. Vegetation on the 2- 
year-old minesoil was a mixture of grasses and legumes. The 23-year-old minesoil had predominantly forest cover of a few prominent tree species with a sparse understory of grasses and legumes (Skousen et al., 1999). Although several tree species were found on this site, the prominent species were black locust and red maple (Acer rubrum L.). Fertilization of the 23year-old minesoil is unknown. However, the 7- and 11-year-old minesoils had $560 \mathrm{~kg} / \mathrm{ha} \mathrm{(500}$ lbs/acre) of 18-46-0 applied, and the 2-year-old minesoil had $672 \mathrm{~kg} / \mathrm{ha}$ (600 lbs/acre) of 15-3015 applied. None of the minesoils were limed.

One very deep and two moderately deep undisturbed native forest soils representing the major soil series (all Dystrudepts) in the county were sampled for comparison. The very deep soil developed in colluvium, and the moderately deep soils developed in residuum. Soil pits approximately $1 \mathrm{~m}$ wide $\mathrm{x} 2 \mathrm{~m}$ long $\mathrm{x} 1^{+} \mathrm{m}$ deep were excavated at each sampling point. Each pedon was described using standard soil survey procedures (Soil Survey Division Staff, 1993). Bulk samples were collected from every horizon described by sieving the rock and soil through a sieve with $1.9 \mathrm{~cm}(3 / 4$ in) openings. The rocks that remained on the sieve were weighed and discarded while the rest was collected as the bulk sample.

\section{Lab Methods}

\section{Physical Analyses}

Each bulk sample was air-dried and processed for laboratory analysis. The samples were dry-sieved to separate the $<2 \mathrm{~mm}$ soil from rock fragments. During the beginning of the sieving process, it was realized that many of the rock fragments were highly weathered. To avoid crushing the highly weathered rock fragments, only enough pressure needed to easily break soil aggregates was used. The laboratory rock fragment weight of each sample was combined with 
the rock fragment weight obtained in the field. Percent rock fragments by weight were calculated.

Approximately 200 grams of soil were left unsieved to be used for aggregate stability analysis. Aggregate stability was determined using the wet sieve method developed by Kemper and Rosenau (1986). The particle size diameter of the analyzed sample was between $6.35 \mathrm{~mm}$ and $2 \mathrm{~mm}$, and was spread evenly on a $2 \mathrm{~mm}$ sieve that had a $0.5 \mathrm{~mm}$ sieve attached to it. Samples were then misted with water three times at three-minute intervals. The sieves were then attached to a mechanical sieving devise and sieved for three minutes. The samples were removed, oven dried, and weighed. After oven drying the samples were wet sieved to correct for primary particles (rock fragments).

Bulk density determination of soil clods from subsurface horizons followed the standard soil survey method (Soil Survey Staff, 1996). The frame excavation method for surface horizons uses a box with an area of $1000 \mathrm{~cm}^{2}$ with 49 holes that have pegs through them. In the field we began by first clearing off all vegetation. Then the frame box was placed on the soil surface to get an initial depth reading by allowing the pegs to drop to the soil surface and measuring the height of each peg above the surface of the box. Then we excavated the horizon and collected the sample until we reached the surface of the next horizon. At that point, we took a final depth reading. The average difference between the initial and final heights of the forty-nine pins is the horizon thickness. The horizon thickness was multiplied by the area of the frame $\left(1000 \mathrm{~cm}^{2}\right)$ to calculate the total volume of soil removed. Once in the laboratory the soil plus rock fragments were oven dried at $105^{\circ} \mathrm{C}$ over night. The samples were then weighed and washed through a 2$\mathrm{mm}$ sieve to correct for rock fragments. After the mass of the rock fragments had been subtracted from the total mass of soil removed, the rock fragment volume was calculated by dividing the 
mass of rocks by the density of the fragments, $2.65 \mathrm{Mg} \mathrm{m}^{-3}$. Next, the volume of soil removed was calculated by subtracting the total volume of rocks from the total volume of soil. The final calculation was for the bulk density $\left(\mathrm{Mg} \mathrm{m}^{-3}\right)$, where the mass of soil without the rocks was divided by the volume of the frame without the rocks. All bulk density values were corrected for rock fragments and reported as bulk density of the $<2 \mathrm{~mm}$ fraction.

Moisture retention was determined using pressure plate and membrane extraction methods at pressures of $33 \mathrm{kPa}$ and $1500 \mathrm{kPa}$ on the $<2 \mathrm{~mm}$ size fraction (Soil Survey Staff, 1996). The water retention difference (WRD) was calculated using the following formula:

$$
\begin{aligned}
& \mathrm{WRD}=[\mathrm{W}(33 \mathrm{kPa})-\mathrm{W}(1500 \mathrm{kPa}) \times \mathrm{Db}(33 \mathrm{kPa}) \times \mathrm{F}] / 100 \\
& \text { where: } \\
& \mathrm{W}(33 \mathrm{kPa})=\text { mass percent moisture retained at } 33 \mathrm{kPa} \\
& \mathrm{W}(1500 \mathrm{kPa})=\text { mass percent moisture retained at } 1500 \mathrm{kPa} \\
& \mathrm{Db}(33 \mathrm{kPa})=\quad \text { bulk density }<2 \mathrm{~mm} \text { fraction at } 33 \mathrm{kPa} \\
& \mathrm{F}=\quad \text { fraction of the fine earth on a volume basis }
\end{aligned}
$$

Texture was determined using a modified pipette method developed by Indorante et al. (1990). This method uses $500 \mathrm{ml}$ fleakers insead of the standard $1000 \mathrm{ml}$ cylinders for sedimentation. Organic matter was digested from all samples with $3 \%$ hydrogen peroxide. The sand was fractionated into 5 classes: very coarse $(2.00-1.00 \mathrm{~mm})$, coarse $(1.00-0.5$ $\mathrm{mm})$, medium $(0.5-0.25 \mathrm{~mm})$, fine $(0.25-0.106 \mathrm{~mm})$, and very fine $(0.106-0.053 \mathrm{~mm})$. This was accomplished by shaking the sand at 160 strokes per minute for 3 minutes (Soil Survey Staff, 1996). 


\section{Chemical Analyses}

Soil $\mathrm{pH}$ was measured in a 1:1 soil to water suspension using a standard $\mathrm{pH}$ probe on an Accumet 915 pH meter (Method 8C1, soil survey division staff, 1996). The following soil reaction classes as defined by the Soil Survey Staff (1993) were used: ultra acid $(\mathrm{pH}<3.5)$, extremely acid ( $\mathrm{pH} 3.5-4.4)$, very strongly acid ( $\mathrm{pH} 4.5-5.0)$, strongly acid ( $\mathrm{pH}$ 5.1-5.5), medium acid ( $\mathrm{pH}$ 5.6-6.0), slightly acid ( $\mathrm{pH}$ 6.1-6.5), neutral (pH 6.6-7.3), mildly alkaline (pH 7.4-7.8), moderately alkaline ( $\mathrm{pH} 7.9-8.4)$, strongly alkaline ( $\mathrm{pH} 8.5-9.0)$, and very strongly alkaline $(\mathrm{pH}$ $\geq 9.0$ ). Electrical conductivity was determined on a 1:2 soil to water suspension by the method presented by Sarrantonio et al. (1996). Total carbon, nitrogen, and sulfur was determined by using a LECO CNS 2000 analyzer. The samples were prepared for analysis by mixing $200 \mathrm{mg}$ of soil with 100 mg ComCat accelerator (Lot No. 1119, Part No. 502-321, LECO Corp., St. Joseph, MI). To calibrate the equipment, five 200-mg sulfamethazine standards and five 100-mg ComCat accelerator blanks were prepared; at least five blanks were analyzed prior to each run of samples. Exchangeable $\mathrm{Al}^{+3}$ was measured by $1 \mathrm{~N} \mathrm{KCl}$ extraction. Again, analysis followed standard soil survey methods, and extracts were analyzed on the AA spectrophotometer for Al and Mn (Method 6G, 6G9, Soil Survey Staff, 1996). Extractable acidity was determined by barium chloride triethanolamine extraction. The $\mathrm{BaCl}_{2}$-triethanolamine (TEA) extraction measured potential or titratable acidity, including all of the acidity generated by $\mathrm{H}^{+}$and $\mathrm{Al}^{+3}$ from permanent and pH dependent exchange sites (Method 6H, 6H5, Soil Survey Staff, 1996). Exchangeable bases $(\mathrm{Ca}, \mathrm{Mg}, \mathrm{K}, \mathrm{Na})$, were determined by ammonium acetate extraction with a $1.0 \mathrm{~N} \mathrm{NH}_{4} \mathrm{OAc}$ buffered at $\mathrm{pH}$ 7.0. Cation Exchange Capacity (CEC) was determined by three methods: (1) ammonium acetate procedure at $\mathrm{pH} 7.0$ (2) $\mathrm{CEC}$ at $\mathrm{pH} 8.2$, by adding sum of bases to barium chloride acidity (3) effective cation exchange capacity (ECEC) computed by summing 
$\mathrm{NH}_{4} \mathrm{OAc}$ extractable bases noted above and $\mathrm{KCl}$ extractable $\mathrm{Al}^{+3}$ (Method 5A3b, Soil Survey Staff, 1996). Exchangeable bases were replaced with $\mathrm{NH}_{4}{ }^{+}$and analysis of the extracted bases $\left(\mathrm{Ca}^{+2}, \mathrm{Na}^{+}, \mathrm{K}^{+}\right.$and $\mathrm{Mg}^{+2}$ ) was performed on the AA (Perkin Elmer Atomic Absorption Spectrophotometer Model 5000, Norwalk, CT) (Method 6N, 6O, 6P, 6Q, Soil Survey Staff, 1996). The ammonium released from the exchange complex was measured with steam distillation by the Kjeltec Auto 1030 Analyzer (Tecator, Sweden). Cation exchange capacity was calculated and values were reported in cmolc kg ${ }^{-1}$ (Method 5A, 5A8, 5A8b, Soil Survey Staff, 1996). Base saturation was calculated by the sum of the bases, and by CEC at pH 7 method (Method 5C, 5C1, 5C3 Soil Survey Staff, 1996). Phosphorus was determined by the Bray-1 method and analyzed on a Perkin Elmer Emission Spectrometer plasma 400 (Soil Survey Staff, 1996). Phosphorus, Al, and Fe was also measured using dithionite citrate bicarbonate extraction (Method 6C3, Soil Survey Staff, 1996)

\section{Productivity Index}

The productivity index (equation 4) developed by Andrews (1992) for midtolerant species was used in this study. For this equation, soil depth was equivalent to total depth, or a maximum depth of $100 \mathrm{~cm}$. A maximum depth of $100 \mathrm{~cm}$ was used since Andrews never went beyond this depth. However, a depth of less than $100 \mathrm{~cm}$ was used since some of the minesoils of my study did not reach the depth of $100 \mathrm{~cm}$.

Phosphorus values used in Andrews P.I. model were developed from Olsen Soil Survey Staff (1996) extractable P. For this project, minesoils and native soils had $\mathrm{pH}$ values optimal for Bray-1 extractable P (Soil Survey Staff, 1996). Thus equation (6) developed by Wolf and Baker (1985) to convert between Olsen and Bray extractable P was employed. 


$$
\text { Bray P1 = -9.65+3.31 Olsen P (6) } \quad r^{2}=0.72
$$

To obtain sufficiency values for bulk density we utilized information from Pierce et al. (1983), which also was used by Andrews to develop his bulk density sufficiency values.

Although Andrews (1992) assigned a sufficiency value of 1.00 to slopes $>35 \%$, the equation gave incorrect results using 35\%. Therfore, I assigned a sufficiency value of 1.00 to slopes $>30 \%$ because I confirmed that this value gave correct results. (A telephone call to Dr. Jim Burger at Virginia Polytechnical University corroborated this discussion.)

\section{Statistical Analysis}

Statistical analysis was used to compare data among minesoils, as well as between minesoils and native soils. Analysis of variance and orthogonal contrasts were used to evaluate and compare differences among minesoils. Comparisons were made for horizon and solum thickness, physical and chemical properties of all surface or A horizons, transition or developed B horizons, which were grouped as one unit, and C horizons. An analysis of variance was used to test for significant differences among ages of minesoils (Dowdy and Wearden 1982).

\section{Classification}

Each described minesoil and native soil pedon was classified to the family level using criteria described in Soil Taxonomy (Soil Survey Staff, 1998). The minesoils were also classified by using proposed classification systems (Sencindiver, 1977, Fanning and Fanning, 1989, and Strain and Evans, 1994). 


\section{Results and Discussion}

\section{Morphology}

\section{Horizon and Structure Development}

Minesoils and native soils are two distinctly different morphological entities.

Native soil morphology is due to thousands, and sometimes tens of thousands, of years of physical and chemical weathering acting upon geologic material. Minesoils also develop through physical and chemical weathering processes, but they are much younger. Minesoils do show signs of pedogenesis but some physical and chemical characteristics are due to human-controlled influences rather than natural factors. These human influences include blasting of rocks into small fragments, compaction due to grading, addition of organic materials, additions of lime and fertilizer, and the seeding of grasses and legumes or the planting of trees.

Processes of soil formation resulted in similar horizon development in each of the native soils (Table 1, Appendix A). All native soils had the following horizons: (1) Oi, leaf and twig litter; (2) A or A/E, dark colored surface mineral horizons with organic matter accumulation; (3) $\mathrm{BA}$, transition horizon between the $\mathrm{A}$ and $\mathrm{Bw}$; and (4) $\mathrm{Bw}$, weakly developed major B horizon. The A horizons had weak or moderate granular structure, while the Bw horizons had weak or moderate subangular blocky structure. The Bw horizons classified as cambic, and all three soils classified as Inceptisols (Soil Survey Staff, 1998). All of the minesoils had A horizons (Table 1, Appendix A). Most minesoils had AC horizons, which are transition horizons between the A and $\mathrm{C}$ horizons with no B horizon. Structure of the minesoil A horizons was predominantly weak or moderate granular with some subangular blocky. Structure of the AC horizons was 
predominantly weak subangular blocky with some granular.

Table 1. Percent of pits having specific horizons described and classified by standard soil survey technique

\begin{tabular}{cccccc} 
Horizon & Native & $1976(23)$ & $1988(11)$ & $1997(7)$ & $1992(2)$ \\
\hline O & 100 & 100 & 33 & 33 & 100 \\
A & 100 & 100 & 100 & 100 & 100 \\
AC & 0 & 83 & 67 & 67 & 67 \\
Bw & 100 & 17 & 0 & 17 & 0 \\
C & 33 & 100 & 100 & 83 & 100 \\
R & 66 & 0 & 0 & 0 & 0
\end{tabular}

In general, structure was strongest in the 23-year-old minesoil and weakest in the 2-year-old minesoil. We described Bw horizons in one 23-year-old and one 7-year-old profile. These horizons had weak subangular blocky structure. Since the structure of the AC and the Bw horizons was similar, the two horizons were separated primarily by color. The AC horizons had colors similar to the A and/or C horizons. The Bw horizons had colors with higher value and/or chroma than the $\mathrm{A}$ and $\mathrm{C}$. The $\mathrm{Bw}$ in the 23-year-old minesoil was thick enough (at least $15 \mathrm{~cm}$ thick) to classify as cambic, but the 7-year-old Bw was too thin (Soil Survey Staff, 1998). However, for the older minesoil to classify as an Inceptisol the lower boundary of the cambic horizon must be at least $25 \mathrm{~cm}$ from the soil surface. Even though this pedon showed many similarities to the native soils its lower boundary was less than $25 \mathrm{~cm}$ from the surface. As a result, it will classify with all other minesoils as an Entisol. Interestingly, a $\mathrm{Cr}$ horizon was described in the 23-01-year-old-minesoil. This particular minesoil was pre SMCRA. The mining methods then were much different than today's methods. The soil at this location may have developed from the original parent material that may have been fractured or even broken up due 
to blasting or a thin layer of overburden material placed on the pavement of the coal bed. The 23-01-year-old-minesoil is the shallowest of all 6 sites of this age, and has the highest clay content in all horizons compared to the other minesoils in this study.

As expected, solum (combined A, AC, Bw and BC horizons) development was considerably greater in native soils than in minesoils (fig. 2). However, minesoil solum thickness tended to increase with age, but there was no significant relationship between solum thickness and time at the 0.05 level. Also there was no significant relationship or trend between slope and solum thickness at the 0.05 level. Average solum development (slope classes combined) per year was $5.9 \mathrm{~cm}$ for the 2-year-old site but only $1.3 \mathrm{~cm}$ for the 23 -year-old site (Table 2).

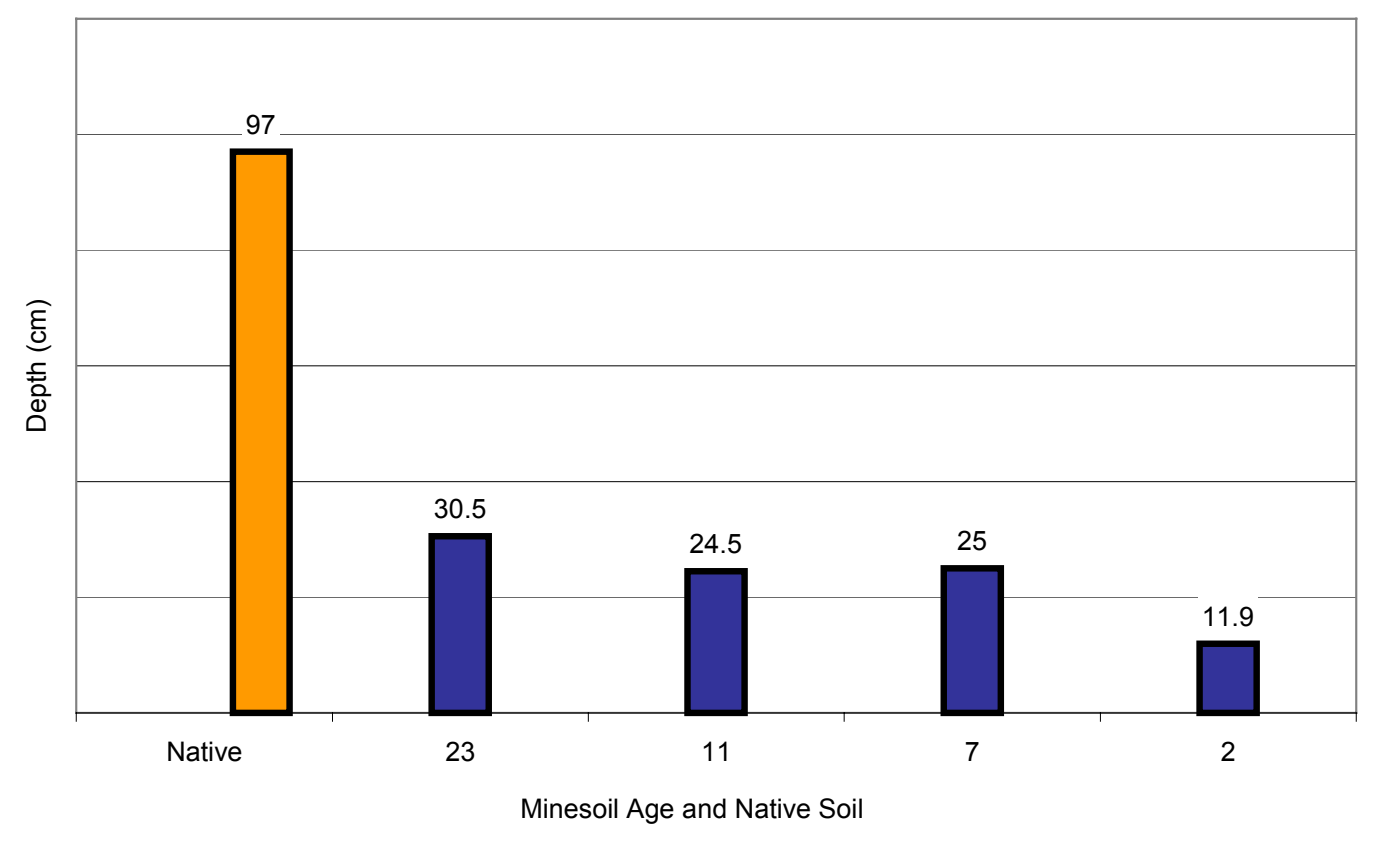

Figure 2: Average depth of native soil and minesoil solum development (A,Bw,AC,BC).

These numbers are very similar to the results of a study reported by Ciolkosz et al. (1985) for nontopsoiled minesoils in western Pennsylvania with slope ranges similar to our study (Table 2). Both our study and the Pennsylvania study indicate that minesoil development is more rapid in the first few years after reclamation. 


\section{Table 2 Average Depth of Minesoil Horizon Development/Year}

\begin{tabular}{cccc}
$\begin{array}{c}\text { Year } \\
\text { Mnesoil } \\
\text { Reclaimed }\end{array}$ & $\begin{array}{c}\text { Minesoil } \\
\text { Age } \\
\text { (Years) }\end{array}$ & $\begin{array}{c}\text { Solum\# } \\
(\mathrm{cm})\end{array}$ & $\begin{array}{c}\text { PA } \\
\text { Solum }^{*} \\
(\mathrm{~cm})\end{array}$ \\
\hline 1997 & 2 & 5.9 & 8.8 \\
1992 & 7 & 3.6 & 3.2 \\
1988 & 11 & 2.2 & 2.6 \\
1976 & 23 & 1.3 & 2 \\
\hline
\end{tabular}

\section{\# Solum = combined thickness of A,AC,Bwand BC horizons. \\ * Approximate values from Ciolkosz et al. (1985) for minesoils of equivalent age in Pennsylvania.}

Interestingly, the A horizons of the native soils were thinner than all minesoil A horizons, except the 2-year-old site (fig. 3). We think this difference is primarily the result of human activities. Revegetation techniques normally disturb a 5 to $10-\mathrm{cm}$ layer at the minesoil surface, and include some organic amendment. Also, it is highly probable that the Native sites had been logged in the last 50 to 100 years. If logging had occurred, then the $\mathrm{O}$ and $\mathrm{A}$ horizons would most likely have been removed, and they have been redeveloping without human influence. For the minesoils, at the 0.05 level, A-horizon thickness increased with time on both slope classes (fig. 3). A-horizon thickness tended to be greater on steep slopes than level slopes, but the differences was not statistically significant at the 0.05 level. One possible explanation for the trend could be increased rooting due to less traffic on the steep slopes. The actual thicknesses described were very similar to A horizons described in studies on sites mined by methods other than mountaintop removal. Roberts et al. (1988b) found that a 4-cm thick A horizon developed on a nontopsoiled minesoil and a 6-cm thick horizon developed on a topsoiled minesoil in one year. When sewage sludge was added to the minesoil, a 1-yr-old A horizon was 11-12 cm thick. Studies of 23 to 29-yr-old minesoils (Ciolkosz et al., 1985; Thurman and Sencindiver, 1986) show that A horizons of 9 to $13 \mathrm{~cm}$ thick had developed. Skousen et al. (1998) reported A 
horizon thickness in the Kaymine, and Sewell series were 7 to $13 \mathrm{~cm}$ thick. Johnson and Skousen (1995) showed horizons of 5 to $15 \mathrm{~cm}$ thick on 15 abandoned mine sites in West Virginia.

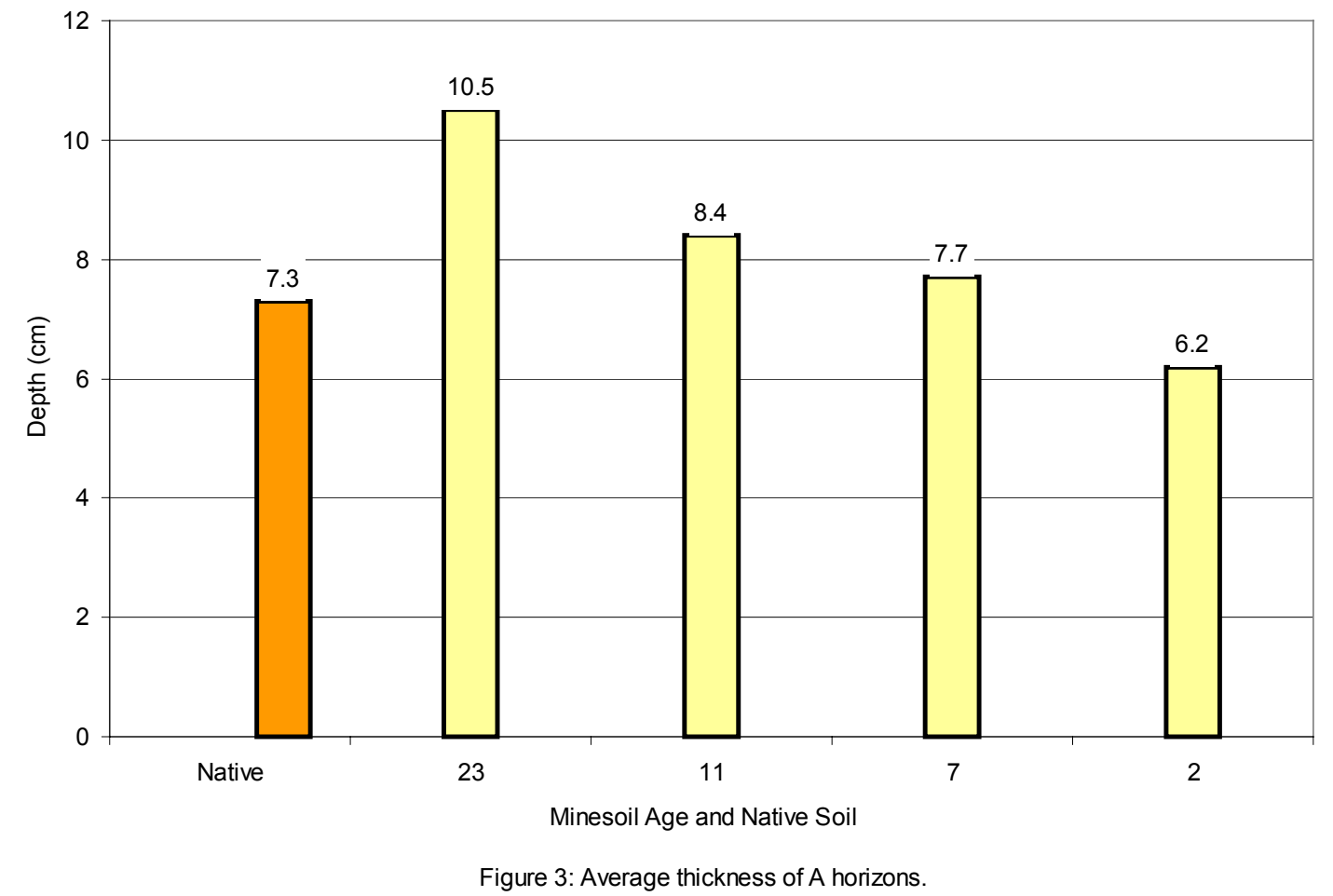

\section{Rock Fragments}

One of the first characteristics recognized when these minesoils were described was the large amount of weakly consolidated disordered fragments of primarily sandstone and shale. The average rock fragment content of all described horizons was approximately $60 \%$. Roberts et al. (1988a) documented that percent rock fragments in surface horizons decrease with time. However, this general trend was not documented in our study. Surface rock fragment content in our study varied as follows: $11 \mathrm{yrs}<23 \mathrm{yrs}<2 \mathrm{yrs}<7 \mathrm{yrs}$. The 23 -year-old minesoils had higher rock-fragment contents in the $\mathrm{C}$ horizons compared to all other minesoils. Also, the 2-year-old minesoils had fewer rock fragments in their subsoils than any other minesoil. These rockfragment differences are probably due to differences in reclamation technique rather than weathering. 


\section{Physical Properties}

\section{Aggregate Stability}

Soil properties vary in the degree of their vulnerability to external forces. One measure of a soil's vulnerability is aggregate stability (Kemper and Rosenau, 1986), which expresses the resistance of soil structural aggregates to breakdown when subjected to disruptive

processes. Freezing and thawing, wetting and drying, additions of organic matter, secretions of microorganisms, earthworm activity, and presence of clay-size particles are some of the factors affecting aggregation in soils. Aggregates generally become more stable over time, and thus total aggregation generally increases as processes of soil genesis develop soil horizons. The native soils, with an average of $63 \%$ in the surface horizon and $62 \%$ in the subsurface horizon, had higher water-stable aggregation than any of the minesoils (fig. 4).

In the minesoils, aggregate stability increased with time (significant at 0.005 level). Aggregation increased with age from a low of $12 \%$ in the subsurface horizon of the 2-year-old minesoil to a high of $54-56 \%$ in the surface horizon of the 11-year-old minesoil and the surface and subsurface horizons of the 23-year-old minesoil. For the 2-, 7-, and 11-year-old minesoils, aggregation of the surface horizon was greater than in the subsurface horizon. These differences can be related to the time of soil development. As these soils age, the aggregation should increase and the two horizons should become more similar as is indicated by the 23 -year-old minesoil and the native soil. No significance was found between aggregate stability and slope at the 0.05 level. These data compare favorably with a study on a site in northeastern West Virginia where Gorman et al. (1999) observed water-stable aggregation of 58\% in the top $8 \mathrm{~cm}$ and $51 \%$ in the 8-16 cm depth of a 9-year-old minesoil. Also, they found that aggregation had increased over time from zero to 9 years. 


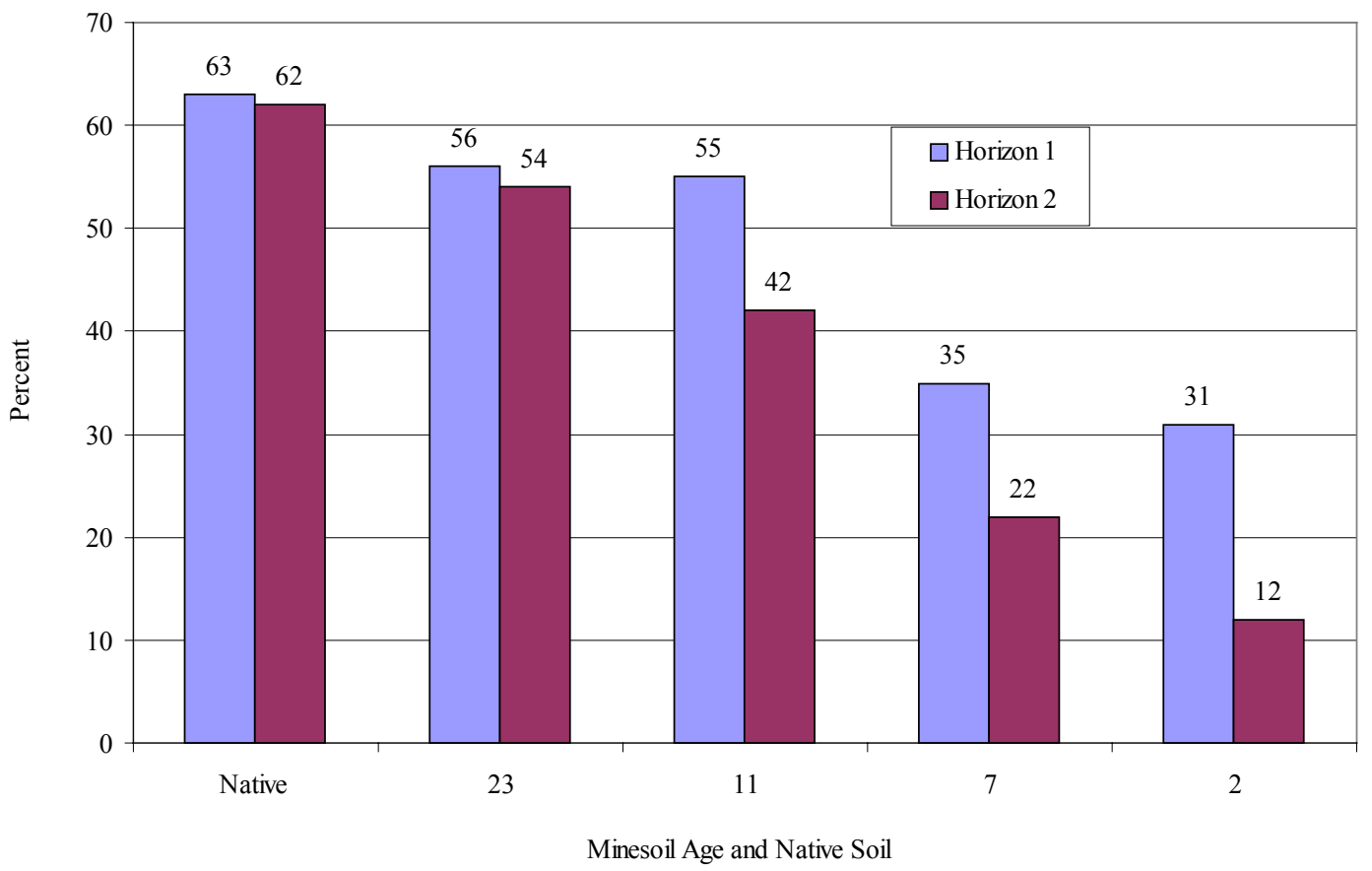

Figure 4: Average water-stable aggregation of the top two horizons

\section{Bulk Density}

Bulk density was not significantly different at the 0.05 level between minesoils and native soils, and there was no significant difference between minesoil bulk density on steep and level slopes. However, bulk density of the minesoils in the surface horizon was somewhat higher than that of the native soils (fig. 5). Bulk density of the minesoil A horizons ranged from a high of $1.1 \mathrm{Mg} / \mathrm{m}^{3}$ in the 11 -year-old site to a low of $0.87 \mathrm{Mg} / \mathrm{m}^{3}$ in the 23 -year-old site. Bulk density tended to increase with depth in all soils, but the values were similar for minesoils and native soils below the A horizon. 


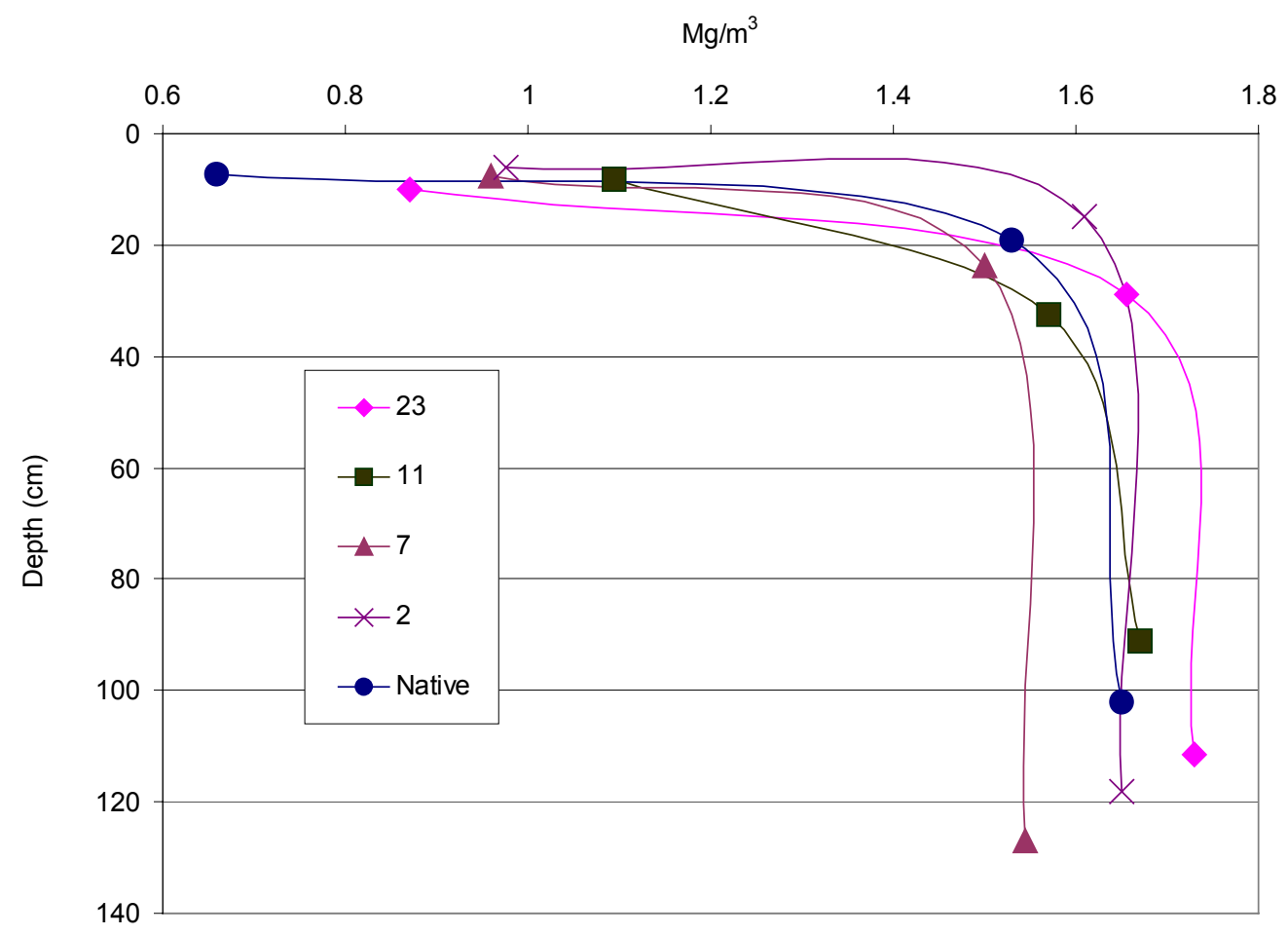

Figure 5: Average bulk density $(<2 \mathrm{~mm})$ with depth of minesoils and native soils.

\section{Particle Size}

Textures of the minesoils were dominantly loamy, but ranged from clay loam to loamy sand. The clay content of the minesoils ranged from a high of $27 \%$ to a low of $6 \%$ (Appendix B). The sand, silt, and clay content followed no pattern in the minesoils. Surface horizons were expected to have lower sand content than the other horizons, as the age of the minesoils decreased due to improved reclamation techniques of topsoil replacement, and an increase with rock percentages with depth. However, the surface horizons generally had approximately the same if not more sand than that of the lower horizons, and these same trends were reported by (Johnson, 1992; Thomas 1987). The medium fraction dominated the sand separate of most of the samples. The dominance of sandstone rock fragments within the minesoil seemed to be the cause of this characteristic. Due to blasting, movement by heavy equipment, and accelerated weathering, the rock fragments have been broken down to yield a medium and fine sand fraction. 


\section{Moisture Retention}

Moisture retention of the minesoils in general was less than that of the native soils (Appendix B) which agrees with other studies (Pederson et al., 1980; Silburn and Crow 1984). However, at lower depths, greater than $50 \mathrm{~cm}$, the minesoils were generally equal to that of the native soils. In general the minesoils had low moisture retention values, possibly due to low organic matter and sandy textures. Water retention difference of the minesoils increased from the surface to lower depths, but some horizons such as C1 had a greater WRD than the C2 horizon. 


\section{Chemical Properties}

\section{pH and Electrical Conductivity}

In general it has been noted that minesoil $\mathrm{pH}$ is influenced by human interactions, such as liming and the placing of alkaline geologic material on the surface during reclamation, and natural interactions, such as leaching caused by rainfall. In general, minesoil $\mathrm{pH}$ tended to decrease with age, and native soils had lower $\mathrm{pH}$ values than all minesoils at all depths except for the 23-year-old minesoil surface horizon (Fig. 6 and Table 3). For all soils, pH tended to increase with depth.

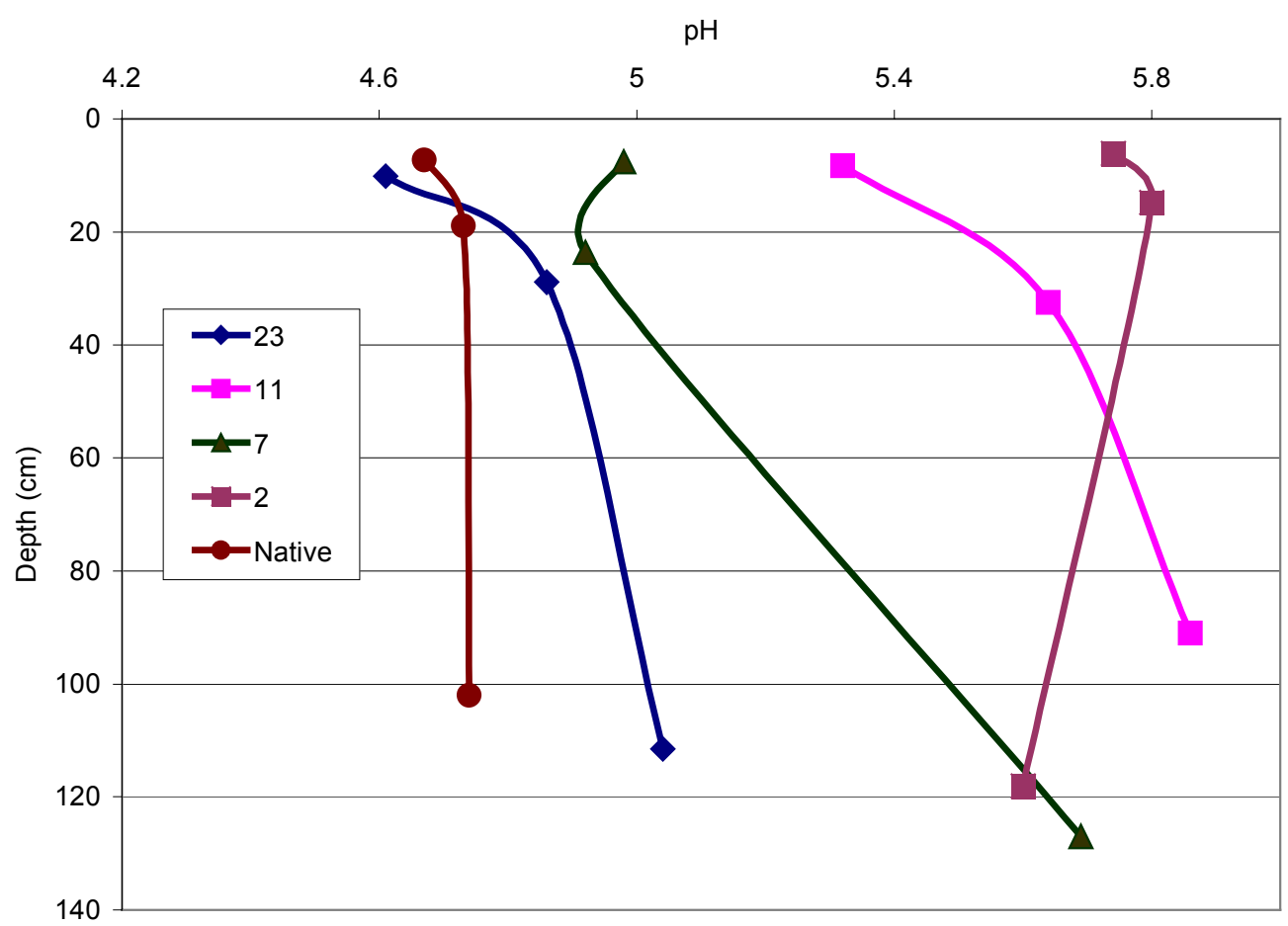

Figure 6: Average $\mathrm{pH}$ values with depth for minesoils and native soils. 
Table 3. Minesoil and Native Soil Chemical Properties by Year of Reclamation and Average Depth

\begin{tabular}{|c|c|c|c|c|c|c|c|c|c|c|c|c|c|c|}
\hline \multirow[b]{2}{*}{ Years } & \multirow[b]{2}{*}{ Layers* } & \multirow[b]{2}{*}{ Depth(cm) } & \multirow[b]{2}{*}{$\mathrm{pH}$} & \multicolumn{3}{|c|}{ Total } & \multicolumn{8}{|c|}{ Extractable } \\
\hline & & & & $C$ & $\mathrm{~N}$ & $S$ & $\mathrm{Ca}$ & $\mathrm{Mg}$ & $\mathrm{Na}$ & $\mathrm{K}$ & $\mathrm{Al}$ & Acidity & $\mathrm{Mn}$ & $\mathrm{P}$ \\
\hline & & & \multicolumn{4}{|c|}{$\%$.. } & \multicolumn{7}{|c|}{....cmol $+\mathrm{kg}^{-1}$. } & $\mathrm{mg} / \mathrm{kg}$ \\
\hline \multirow[t]{3}{*}{23} & 1 & 10 & 4.6 & 2.9 & 0.09 & 0.04 & 2.8 & 1.7 & 0.03 & 0.14 & 1.0 & 8.1 & 0.12 & 8.1 \\
\hline & 2 & 29 & 4.9 & 2.4 & 0.04 & 0.05 & 2.7 & 1.9 & 0.04 & 0.10 & 0.8 & 5.7 & 0.09 & 4.3 \\
\hline & 3 & 112 & 5.0 & 2.6 & 0.03 & 0.06 & 2.5 & 2.2 & 0.00 & 0.00 & 0.5 & 3.9 & 0.05 & 3.6 \\
\hline \multirow[t]{3}{*}{11} & 1 & 8 & 5.3 & 2.1 & 0.02 & 0.04 & 1.7 & 0.7 & 0.00 & 0.09 & 0.2 & 3.9 & 0.03 & 11.6 \\
\hline & 2 & 33 & 5.6 & 2.4 & 0.02 & 0.06 & 1.6 & 1.0 & 0.00 & 0.10 & 0.4 & 3.0 & 0.03 & 1.7 \\
\hline & 3 & 91 & 5.9 & 2.8 & 0.01 & 0.06 & 2.0 & 0.8 & 0.00 & 0.10 & 0.1 & 2.7 & 0.02 & 1.9 \\
\hline \multirow[t]{3}{*}{7} & 1 & 8 & 5.0 & 3.7 & 0.02 & 0.07 & 1.2 & 1.1 & 0.11 & 0.12 & 0.8 & 3.9 & 0.03 & 12.6 \\
\hline & 2 & 24 & 4.9 & 3.7 & 0.01 & 0.10 & 1.0 & 1.2 & 0.04 & 0.11 & 0.9 & 3.9 & 0.04 & 6.6 \\
\hline & 3 & 127 & 5.7 & 2.3 & 0.00 & 0.05 & 1.3 & 1.2 & 0.06 & 0.07 & 0.5 & 1.6 & 0.02 & 1.9 \\
\hline \multirow[t]{3}{*}{2} & 1 & 6 & 5.7 & 3.9 & 0.02 & 0.06 & 2.7 & 2.7 & 0.00 & 0.20 & 0.3 & 3.3 & 0.06 & 69.4 \\
\hline & 2 & 15 & 5.8 & 2.9 & 0.00 & 0.04 & 2.4 & 2.6 & 0.00 & 0.10 & 0.3 & 2.9 & 0.05 & 27.7 \\
\hline & 3 & 118 & 5.6 & 3.4 & 0.00 & 0.06 & 2.5 & 2.9 & 0.00 & 0.10 & 0.4 & 3.7 & 0.06 & 3.6 \\
\hline \multirow[t]{3}{*}{ Native } & 1 & 7 & 4.7 & 7.9 & 0.25 & 0.07 & 5.5 & 1.0 & 0.00 & 0.18 & 1.7 & 17.6 & 0.25 & 24.7 \\
\hline & 2 & 19 & 4.7 & 0.8 & 0.00 & 0.03 & 0.7 & 0.4 & 0.00 & 0.08 & 2.7 & 7.1 & 0.07 & 2.9 \\
\hline & 3 & 102 & 4.7 & 0.3 & 0.00 & 0.04 & 0.9 & 1.3 & 0.00 & 0.10 & 2.5 & 5.4 & 0.02 & 0.7 \\
\hline
\end{tabular}

*1 = Average of all $A, A 1, A 2, A / E$ horizons

$2=$ Average of all $\mathrm{AC}, \mathrm{BA}, \mathrm{Bw}, \mathrm{BC}$ horizons

$3=$ Average of all $\mathrm{CB}, \mathrm{C} / \mathrm{B}, \mathrm{C}, \mathrm{C} 1, \mathrm{C} 2, \mathrm{C} 3, \mathrm{C} 4$ horizons

Electrical conductivity (EC) values estimate the salt content of the soils. All soils in our study had electrical conductivity values below $0.3 \mathrm{dS} / \mathrm{m}$ (fig. 7). Native soils had higher salt contents in the surface horizon than the minesoils. Salt contents were higher in the surface horizon than in the subsoil for the native soils and all minesoils, except the 2-year-old minesoils. Although the EC values of the 2-year-old minesoils were very low, they were two to three times higher than EC of all other soils at the same depth. It is probable that these higher values were simply a result of overburden placement or lingering fertilizer effects. Salt effects on most plants are negligible at EC values of 0-2 dS/m (Richards, 1954). Some acid minesoils have been observed to have EC values of $4 \mathrm{dS} / \mathrm{m}$ or higher in all or part of the profile (Ciolkosz et al., 1985). These high EC values will restrict the yields of some crops. 


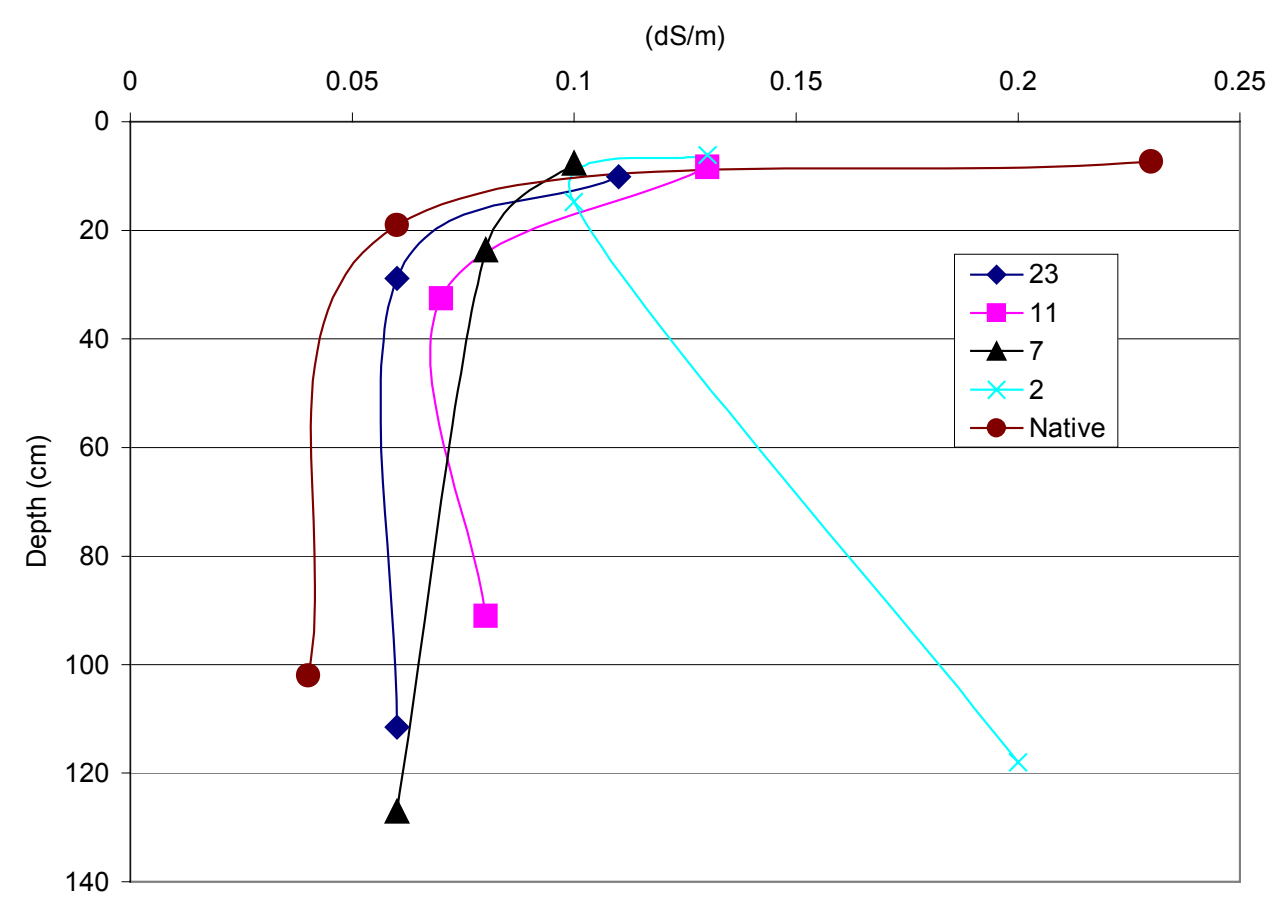

Figure 7: Average electrical conductivity for minesoils and native soils.

\section{Exchangeable acidity, Aluminum, and Manganese}

At low $\mathrm{pH}$, certain elements such as $\mathrm{Al}$ and $\mathrm{Mn}$ become toxic to plants and may contribute to vegetation failures on minesoils (Berg and Vogel, 1968; Berg and Vogel, 1973; Fleming et al., 1974). Extractable Al was higher at all depths in the native soil, because of its correlation to lower $\mathrm{pH}$ values (Table 3). Manganese was twice as high in the surface of the native soil than that of the 23-year-old minesoil. However, the 23-year-old minesoil had higher Mn levels in the lower horizons than that of the native soils, and it had higher levels of Mn than all the other minesoils. Since all soils studied had relatively the same concentrations of Mn, parent material must be having a major effect on this chemical property.

Acidity in minesoils can arise from rapid leaching of bases in a humid environment, or the oxidation of pyritic material within the minesoils (Mays and Bengston, 1978). Since total sulfur 
values are low in these minesoils (Table 3), it is assumed that very little acidity resulted from pyrite oxidation. The average extractable soil acidity was greater in the native soils than the minesoils at all depths (Table 3). The 23-year-old minesoils had the highest extractable acidity of all the minesoils with an average of $5.9 \mathrm{cmol}^{+} \mathrm{kg}^{-1}$. The average extractable acidity of all soils tended to decrease with depth except for the 2-year-old minesoil where it increased in the lower horizons.

\section{Nitrogen, Phosphorus, Sulfur, and Carbon}

In areas of the eastern coal region where acidic minesoils occur, $\mathrm{P}, \mathrm{N}$, and water have been reported as being the most common limiting factors of obtaining adequate vegetation cover (Barnhisel, 1977). Previous studies of West Virginia minesoils of different ages, land uses, and parent materials have reported total minesoil $\mathrm{N}$ generally ranging from $0.03 \%$ to $0.6 \%$ with most minesoil horizons having less than 0.3\% (Adamo, 1986; Sencindiver, 1977; Vandevender and Sencindiver, 1982). All soils in this study had less than $0.1 \%$ average total $\mathrm{N}$ (Fig. 8) and all minesoils had lower values than the native soils, where most $\mathrm{N}$ was in the surface horizon (Table 3). Total $\mathrm{N}$ tended to increase with age within the minesoils. However, when steep and level slopes were compared no significance was found between slope and percent Nitrogen for surface horizons at the 0.05 level. The 23 -year-old minesoil had the highest total $\mathrm{N}$ levels, and the 2year-old minesoil had the lowest (Fig. 8). 


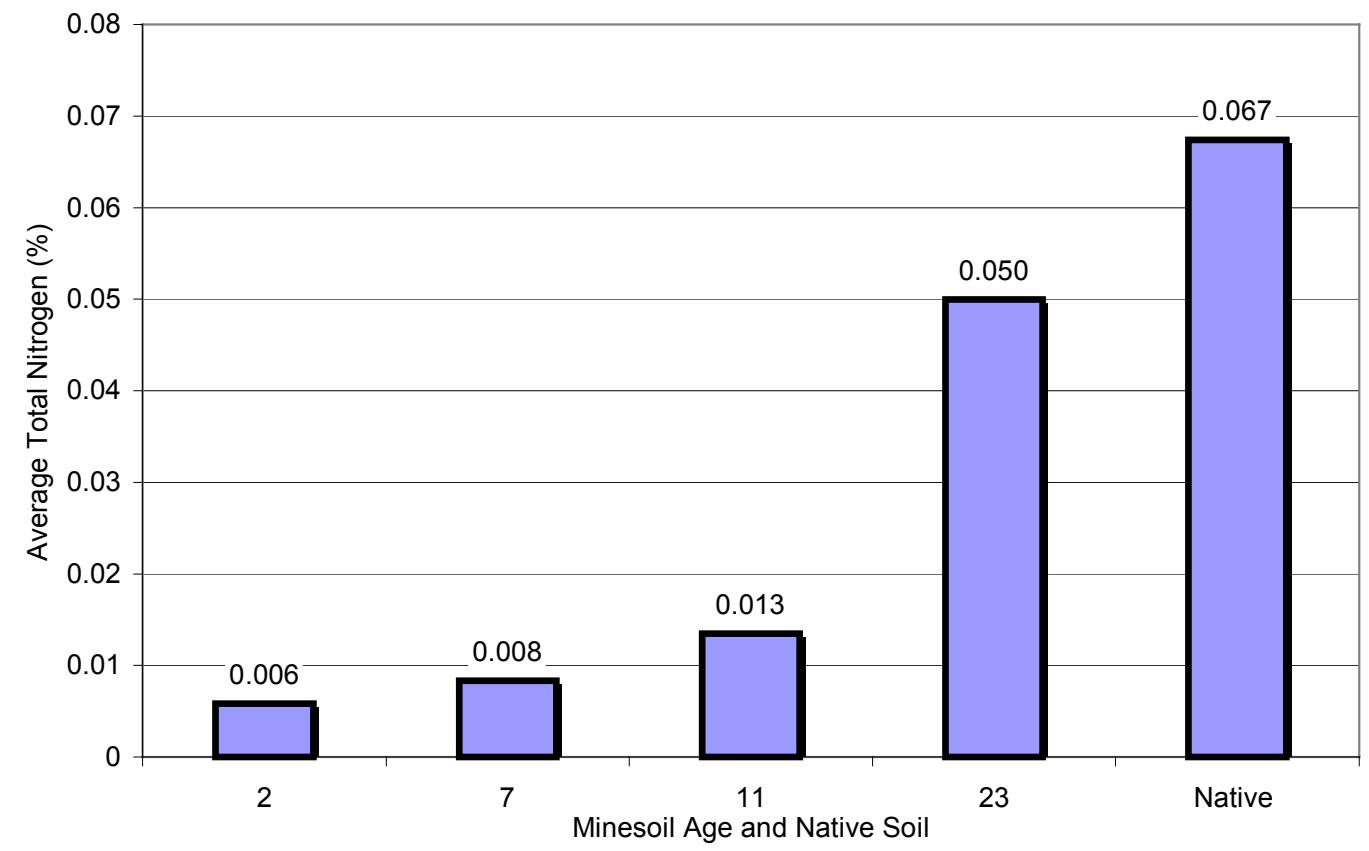

Figure 8: Average total nitrogen of all minesoil and native soil horizons by age.

Phosphorus is a major limiting nutrient in Appalachian minesoils (Plass and Vogel, 1973).

Researchers in West Virginia have reported Bray extractable P levels ranging from very low to moderate in minesoils (Adamo, 1986; Dant, 1984). A similar range was found in my study. The 2-year-old minesoils in this study had higher extractable P values than other minesoils and the native soils (Fig. 9). The higher levels of $\mathrm{P}$ in the 2-year-old minesoils are believed to be a residual result of fertilization during revegetation. Phosphorus seemed to be concentrated in the top two horizons of the native soils, and tended to decrease with depth (Table 3 ). The same trend was indicated in the majority of the minesoils. This trend of decreasing $\mathrm{P}$ with depth may be the result of biocycling or root interaction. 


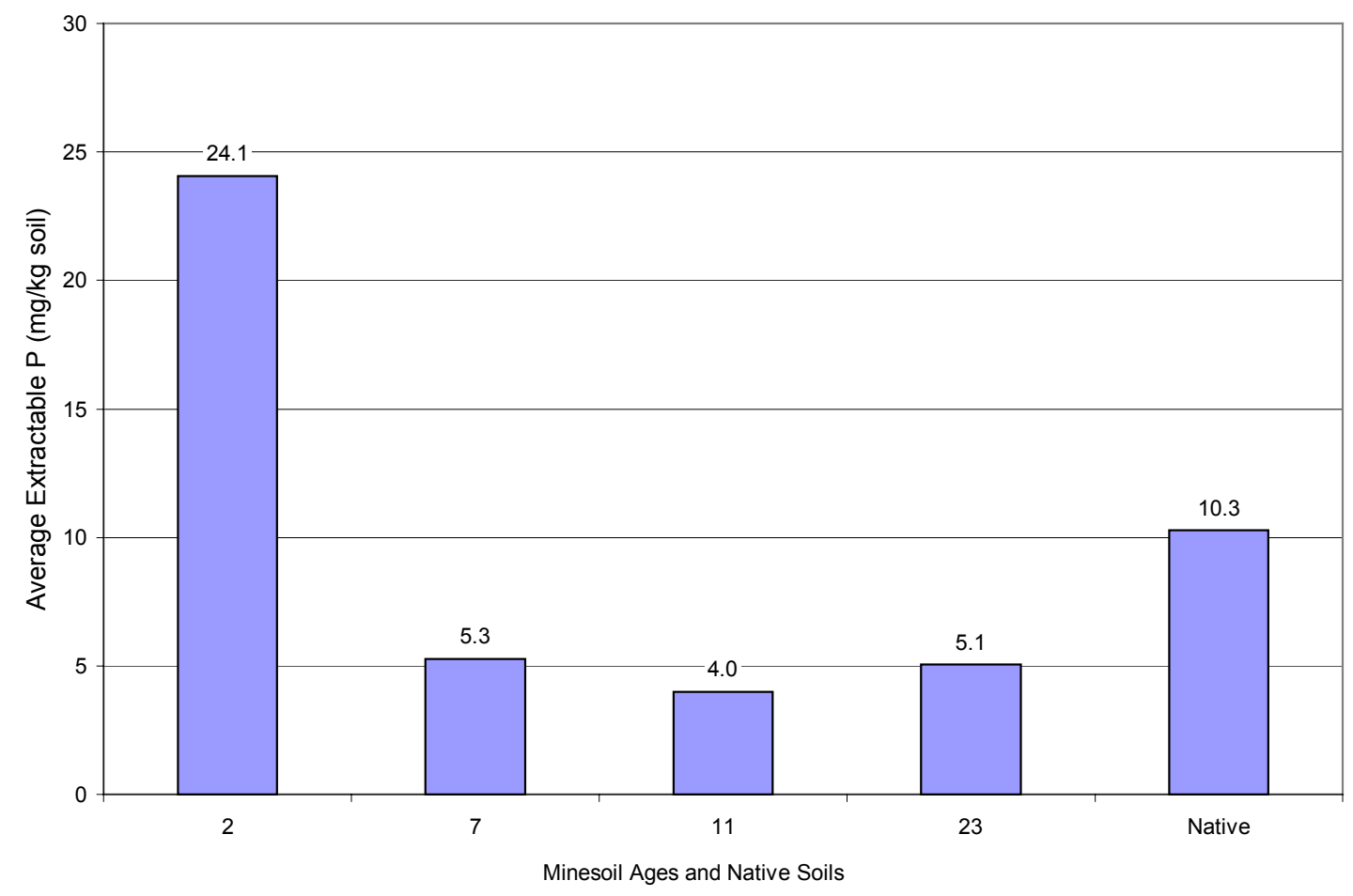

Figure 9: Average extractable phophorus of all minesoil and native soil horizons by age.

Wolf et al. (1990) found $\mathrm{S}$ values as high as $0.45 \%$ in minesoils located in similar areas of southern West Virginia as those sampled in this study. However, the overburden and coal mined in the area of my study has little or no pyritic material (Barlow and Erwin, 1974). Therefore, S values in the minesoils and native soils were $0.1 \%$ or less (Table 3 ).

Most native soils, other than soils developing in fluvial deposits, have regular decreasing carbon with depth as was seen in soils analyzed for this study (Table 3). However, irregular distribution of $\mathrm{C}$ with depth is a common trend in minesoils (Ciolkosz et al., 1985; Pederson and Rogowski, 1978; Smith et al., 1971; Thurman and Sencindiver, 1986), and also was demonstrated in these mountaintop removal minesoils. 
The native soils had the highest total $\mathrm{C}$ in the surface with $7.9 \%$ (Fig. 10), and the 11-year-old minesoils had the lowest with $2.1 \%$ total $\mathrm{C}$ in the surface. However, total $\mathrm{C}$ increased with depth in the 11 -year-old minesoil to $2.8 \%$ (Table 3). One explanation for the irregular distribution is the presence of carbolithic shale and coal fragments throughout the minesoils. The combustion method used to determine $\mathrm{C}$ would likely measure fossil carbon in coal, carbonaceous shale material, and soil organic matter $\mathrm{C}$.

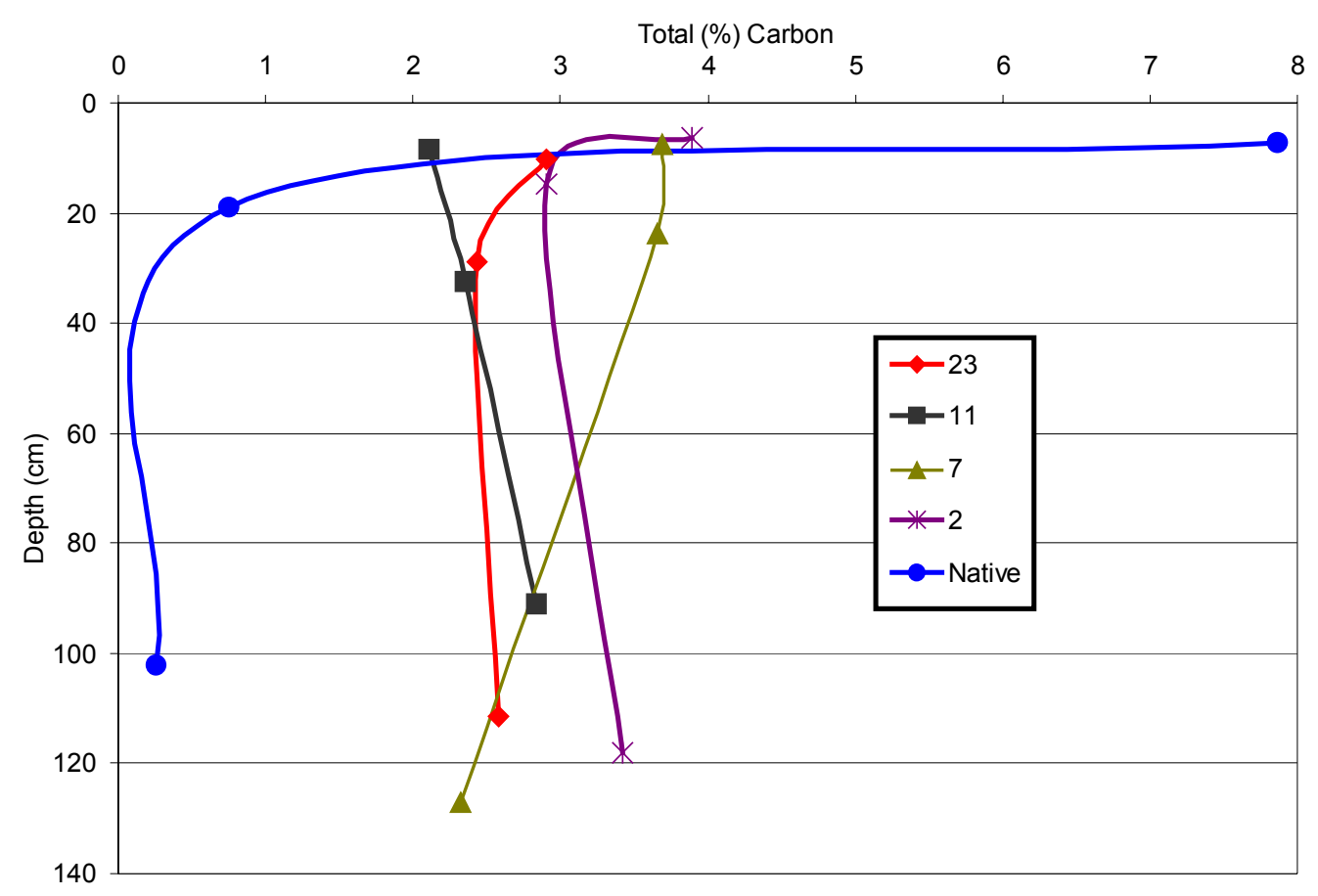

Figure 10: Average percent carbon with depth of minesoils and native soils.

\section{Exchangeable Bases}

Of the four bases analyzed in both minesoils and native soils, $\mathrm{Ca}$ and $\mathrm{Mg}$ were most abundant (Table 3). The Na content was low in the minesoils because $\mathrm{Na}$ is typically not found in geologic material of the mined area. Potassium was lower than expected since most parent materials in the area have K-bearing minerals associated with them. Earlier studies of minesoils in southern West Virginia (Skousen et al., 1998; Wolf et al., 1990) reported K levels of 0.3-0.6 
$\mathrm{cmol}^{+} \mathrm{kg}^{-1}$. In our study, the highest $\mathrm{K}$ level was $0.1 \mathrm{cmol}+\mathrm{kg}^{-1}$ in the 23 -year-old soil. The higher levels of $\mathrm{K}$ found in the other studies may be due to higher clay content in those minesoils than the minesoils of this study.

Total extractable bases were highest in the 2-year-old minesoils, and lowest in the native soils (Fig. 11). The higher bases in the 2-year-old minesoil could be the result of several things, i.e. (1) higher bases in the parent material, (2) less uptake by vegetation because of shortness of time, and (3) less leaching because of shortness of time and low rooting. However, the 23- yearold minesoil had higher bases than the 7 and 11-year-old minesoils. These higher base values may be the result of an older, tree vegetated site bringing bases to the surface because of deep rooting depths and returning bases to the soil surface through leaf and limb fall. However, the higher bases could be an indication that the minesoils are only reflecting the original base status of the premined soil and geology.

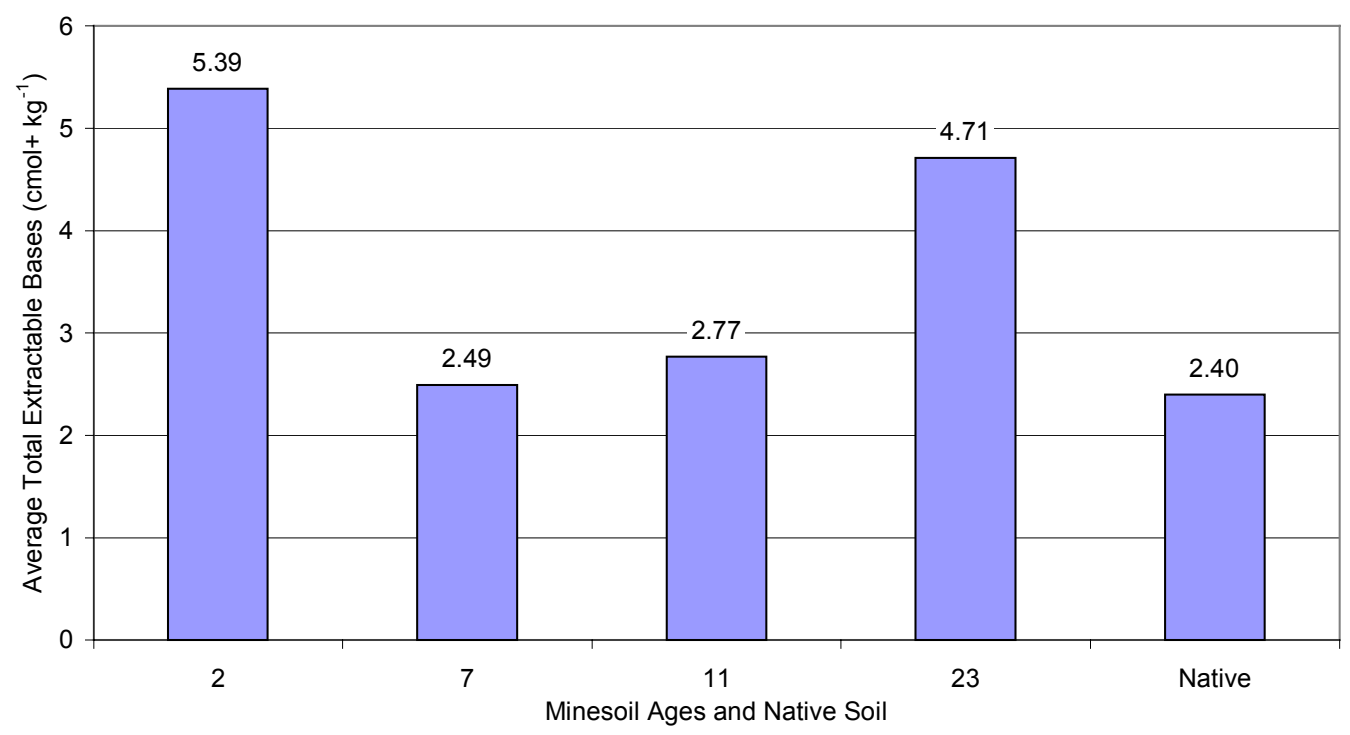

Figure 11: Average total extractable bases of all minesoil and native soil horizons by age. 
Cation exchange capacity in the surface horizons of the native soils was higher than that of the minesoils primarily because organic matter was higher in the native soils (Table 4). However, base saturation was higher in all minesoils than the native soils.

Table 4. Minesoil and Native Soil Calculated Chemical Properties by Year of Reclamation and Average Depth

\begin{tabular}{ccccccccc}
\multicolumn{2}{c}{ Years Layers } & Depth $(\mathrm{cm})$ & CEC-7 & CEC-8.2 & ECEC & Base Sat. 7 & Base Sat. 8.2 & Al Sat. \\
\hline \multirow{2}{*}{23} & 1 & 10 & 9.8 & 12.9 & 6.5 & 48 & 37 & 17.5 \\
& 2 & 29 & 7.3 & 10.5 & 5.5 & 65 & 45 & 14.2 \\
& 3 & 112 & 5.9 & 8.6 & 5.2 & 79 & 54 & 10.4 \\
11 & 1 & 8 & 4.9 & 6.4 & 2.7 & 51 & 39 & 8.6 \\
& 2 & 33 & 5.0 & 6.4 & 3.3 & 53 & 41 & 11.7 \\
& 3 & 91 & 4.2 & 5.5 & 3.0 & 68 & 51 & 4.2 \\
7 & 1 & 8 & 6.0 & 6.3 & 3.3 & 41 & 39 & 24.4 \\
& 2 & 24 & 4.4 & 6.3 & 3.4 & 55 & 38 & 28.0 \\
& 3 & 127 & 3.7 & 4.1 & 3.1 & 69 & 63 & 17.6 \\
2 & 1 & 6 & 6.4 & 8.8 & 5.8 & 87 & 63 & 5.5 \\
& 2 & 15 & 6.6 & 8.0 & 5.5 & 78 & 64 & 6.2 \\
& 3 & 118 & 7.5 & 9.1 & 5.8 & 72 & 60 & 7.0 \\
Native & 1 & 7 & 22.4 & 24.3 & 8.3 & 30 & 27 & 20.2 \\
& 2 & 19 & 7.1 & 8.2 & 3.8 & 16 & 14 & 69.9 \\
& 3 & 102 & 7.3 & 7.6 & 4.7 & 30 & 29 & 53.1 \\
& & & & & & & & \\
\hline
\end{tabular}

*1 = Average of all $A, A 1, A 2, A / E$ horizons

$2=$ Average of all $A C, B A, B w, B C$ horizons

$3=$ Average of all $C B, C / B, C, C 1, C 2, C 3, C 4$ horizons 


\section{Minesoil Classification}

\section{Minesoil Classification}

\section{Accepted Taxonomy}

The National Cooperative Soil Survey of the United States uses Soil Taxonomy (Soil Survey Staff, 1999) to classify all soils, including minesoils. However, some soil scientists argue that the accepted classes of Soil Taxonomy do not readily identify a minesoil from other soils at the higher levels of the system (Sencindiver and Ammons, 2000). Minesoils commonly have unique management requirements, and the taxonomic name should relate to that uniqueness. Therefore several modifications to Soil Taxonomy for various anthropogenic soils have been proposed (Fanning and Fanning,1989; Kosse,1988; Sencindiver, 1977; Strain and Evans, 1994). Minesoils in this study were classified by the current accepted system (Soil Survey Staff, 1999), and by the proposed systems. Table 5 presents an example to provide some information on the various categories and classes in Soil Taxonomy.

Three native soils were sampled to represent Berks, Matewan, and Highsplint, major series of the region prior to mining. The classification of the sampled soils fit the official classification of the series (http://www.statlab.iastate.edu/cgi-bin/osd/osdname.cgi), except for CEC activity class of Berks and Matewan (Table 6). The CEC activity class of both Matewan and Berks series is active, but data for the soils sampled in this study fit the semiactive class. Therefore, the "bestfit" series was used for each site, including the minesoils (Table 5). 
Table 5. Example of minesoil classification in Soil Taxonomy (Soil Survey Staff, 1999)

$\begin{array}{ll}\text { Category } & \text { Class } \\ \text { Order: } & \text { Entisols } \\ \text { Suborder: } & \text { Orthents } \\ \text { Great Group: } & \text { Udorthents } \\ \text { Subgroup: } & \text { Typic Udorthents } \\ \text { Family: } & \begin{array}{l}\text { loamy-skeletal, mixed, active, acid } \\ \text { mesic Typic Udorthents }\end{array} \\ \text { Series } & \text { Bethesda }\end{array}$

${ }^{*}$ At the family category loamy-skeletal= particles size class, mixed= mineraology class, active $=$ CEC activity class, acid $=$ reaction class, and Mesic $=$ soil temperature class.

In the current classes of Soil Taxonomy, all minesoils are classified similarly (Table 6). The similarities are found in the higher categories of order through subgroup, i.e. all are Typic Udorthents, and the family category where all minesoils have a loamy-skeletal particle size class, a mixed mineralogy class, and a mesic soil temperature regime. Differences appear in the CEC activity class and the soil reaction class. All minesoils were placed into an accepted series. The CEC activity class was not used for classification at the series level because none of the accepted series descriptions (http://www.statlab.iastate.edu/cgi-bin/osd/osdname.cgi) have been updated to include the CEC activity class. The CEC activity class provided in Table 6 is the class determined from the data for each sample site in this study. It may or may not be the resulting accepted CEC activity class for the series. Therefore, some of the series listed in Table 6 were listed for more than one CEC activity class. When the minesoil series descriptions are officially updated by adding the CEC activity class, series names for soils sampled in this study may change. 
Table 6. Minesoil and Native Soil Classification by USDA Soil Taxonomy (Soil Survey Staff, 1999)

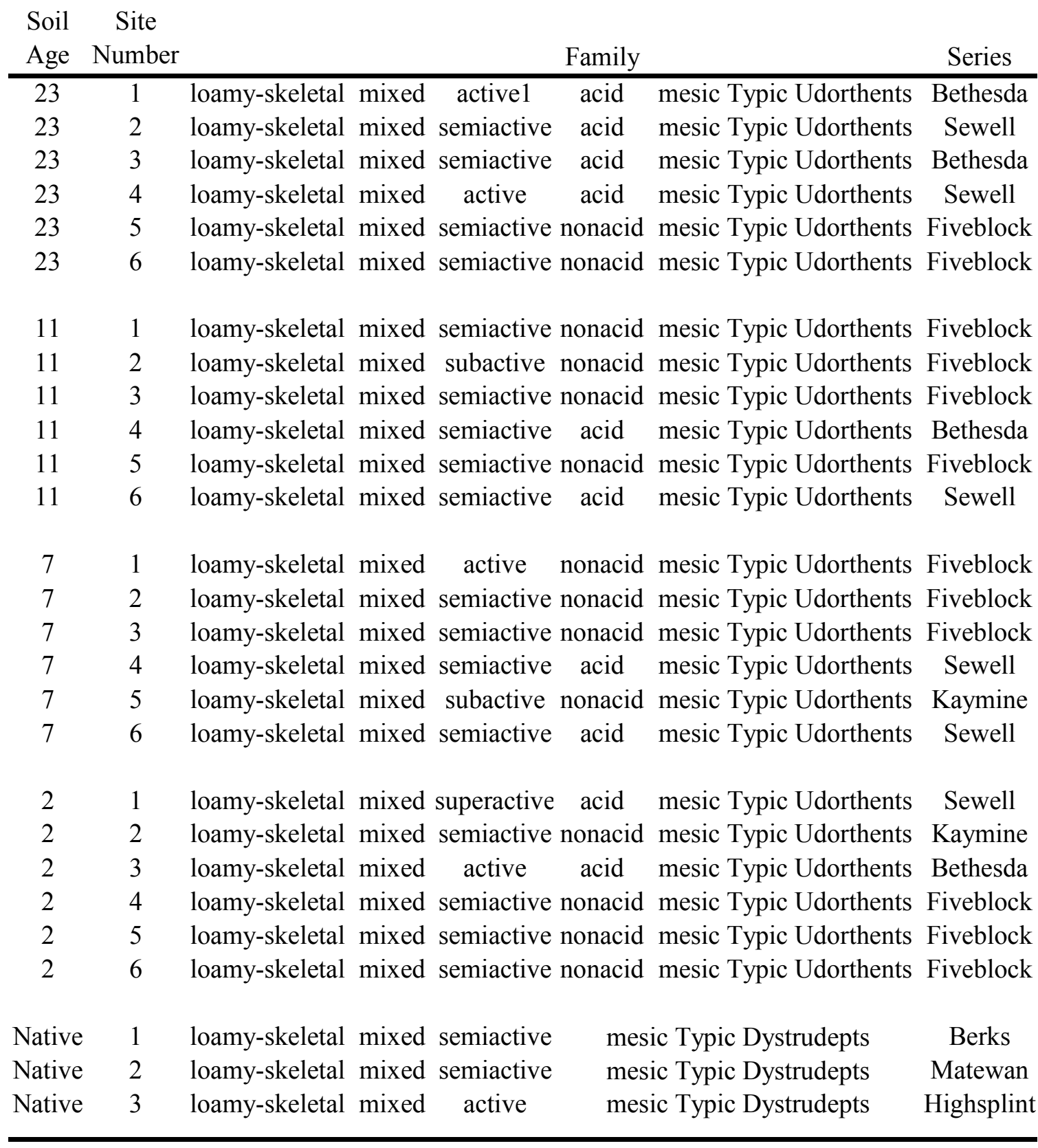

1 Activity class, although presented here, was not used to identify series of minesoils.

All of the minesoils in this study fit one of four series: Bethesda, Sewell, Fiveblock, or Kaymine. Fiveblock and Kaymine are nonacid, while Bethesda and Sewell are acid. Bethesda and Kaymine have $18 \%$ or more clay in the control section, while Fiveblock and Sewell have 
less than $18 \%$ clay.

Classification of minesoils was not uniform across age or slope. All four series were represented on the two-year-old site, while three of the series were represented on each of the other sites.

\section{Minesoils Classified by Proposed Methods}

The minesoils were classified by three different proposed methods, and will be presented by chronological order. The first proposed method (Table 7) was developed at West Virginia University (Sencindiver, 1977), where a new suborder called Spolents was proposed. Spolents are defined as soils that include recently deposited earthy materials resulting from surface mining or other earth-moving operations, or deposits of solid wastes accumulated in connection with some phase of mining or other industrial activity, or deposits from such activities as sanitary landfills. The main characteristics separating each minesoil, were rock fragment type and reaction class which are summarized by Sencindiver (1977). Two of the nine subgroups proposed at WVU were used to classify the minesoils in the current study. Plattic is a term developed to describe minesoils where sandstone makes up at least $65 \%$ of the rock fragments within the control section. Typic describes soils that have at least $10 \%$ rock fragments in the control section with no one rock type dominating, and that do not qualify for any other subgroup. New reaction classes also were proposed. The two classes that were used to classify minesoils in this study were acid: $\mathrm{pH} 4.0$ to 5.5, and neutral: $\mathrm{pH} 5.6$ to 8.0. Althought Sencindiver (1977) did not include CEC activity classes, these classes were added for this study (Table 7). 
Table 7. Minesoil Soil Classification by West Virginia University Proposed Method (Sencindiver, 1977)

\begin{tabular}{|c|c|c|c|c|c|c|}
\hline $\begin{array}{l}\text { Soil } \\
\text { Age }\end{array}$ & $\begin{array}{c}\text { Site } \\
\text { Number }\end{array}$ & & & & & \\
\hline 23 & 1 & loamy-skeletal & mixed & $\overline{\text { active }}$ & acid & mesic Typic Udispolents \\
\hline 23 & 2 & loamy-skeletal & mixed & semiactive & acid & mesic Plattic Udispolents \\
\hline 23 & 3 & loamy-skeletal & mixed & semiactive & acid & mesic Typic Udispolents \\
\hline 23 & 4 & loamy-skeletal & mixed & active & acid & mesic Plattic Udispolents \\
\hline 23 & 5 & loamy-skeletal & mixed & semiactive & neutral & mesic Plattic Udispolents \\
\hline 23 & 6 & loamy-skeletal & mixed & semiactive & neutral & mesic Plattic Udispolents \\
\hline 11 & 1 & loamy-skeletal & mixed & semiactive & neutral & mesic Plattic Udispolents \\
\hline 11 & 2 & loamy-skeletal & mixed & subactive & acid & mesic Plattic Udispolents \\
\hline 11 & 3 & loamy-skeletal & mixed & semiactive & neutral & mesic Plattic Udispolents \\
\hline 11 & 4 & loamy-skeletal & mixed & semiactive & acid & mesic Typic Udispolents \\
\hline 11 & 5 & loamy-skeletal & mixed & semiactive & neutral & mesic Plattic Udispolents \\
\hline 11 & 6 & loamy-skeletal & mixed & semiactive & acid & mesic Plattic Udispolents \\
\hline 7 & 1 & loamy-skeletal & mixed & active & neutral & mesic Plattic Udispolents \\
\hline 7 & 2 & loamy-skeletal & mixed & semiactive & neutral & mesic Plattic Udispolents \\
\hline 7 & 3 & loamy-skeletal & mixed & semiactive & neutral & mesic Plattic Udispolents \\
\hline 7 & 4 & loamy-skeletal & mixed & semiactive & acid & mesic Plattic Udispolents \\
\hline 7 & 5 & loamy-skeletal & mixed & subactive & acid & mesic Plattic Udispolents \\
\hline 7 & 6 & loamy-skeletal & mixed & semiactive & acid & mesic Plattic Udispolents \\
\hline 2 & 1 & loamy-skeletal & mixed & superactive & acid & mesic Plattic Udispolents \\
\hline 2 & 2 & loamy-skeletal & mixed & semiactive & neutral & mesic Typic Udispolents \\
\hline 2 & 3 & loamy-skeletal & mixed & active & acid & mesic Typic Udispolents \\
\hline 2 & 4 & loamy-skeletal & mixed & semiactive & neutral & mesic Plattic Udispolents \\
\hline 2 & 5 & loamy-skeletal & mixed & semiactive & neutral & mesic Plattic Udispolents \\
\hline 2 & 6 & loamy-skeletal & mixed & semiactive & neutral & mesic Plattic Udispolents \\
\hline
\end{tabular}

The second method proposed for classifying minesoils was developed by Fanning and

Fanning (1989). Using this proposed method all minesoils would be classified as Spolic

\section{Udorthents (Table 8).}


Table 8. Minesoil Classification by Fanning and Fanning (1989) Proposed Method

\begin{tabular}{cccccc} 
Soil Age & Site Number & & & \\
\hline 23 & 1 & loamy-skeletal mixed & active & acid & mesic Spolic Udorthents \\
23 & 2 & loamy-skeletal mixed & semiactive & acid & mesic Spolic Udorthents \\
23 & 3 & loamy-skeletal mixed & semiactive & acid & mesic Spolic Udorthents \\
23 & 4 & loamy-skeletal mixed & active & acid & mesic Spolic Udorthents \\
23 & 5 & loamy-skeletal mixed & semiactive nonacid mesic Spolic Udorthents \\
23 & 6 & loamy-skeletal mixed & semiactive & nonacid mesic Spolic Udorthents
\end{tabular}

$11 \quad 1$ loamy-skeletal mixed semiactive nonacid mesic Spolic Udorthents

112 loamy-skeletal mixed subactive nonacid mesic Spolic Udorthents

113 loamy-skeletal mixed semiactive nonacid mesic Spolic Udorthents

114 loamy-skeletal mixed semiactive acid mesic Spolic Udorthents

115 loamy-skeletal mixed semiactive nonacid mesic Spolic Udorthents

116 loamy-skeletal mixed semiactive acid mesic Spolic Udorthents

$7 \quad 1 \quad$ loamy-skeletal mixed active nonacid mesic Spolic Udorthents

72 loamy-skeletal mixed semiactive nonacid mesic Spolic Udorthents

$7 \quad 3$ loamy-skeletal mixed semiactive nonacid mesic Spolic Udorthents

74 loamy-skeletal mixed semiactive acid mesic Spolic Udorthents

75 loamy-skeletal mixed subactive nonacid mesic Spolic Udorthents

76 loamy-skeletal mixed semiactive acid mesic Spolic Udorthents

21 loamy-skeletal mixed superactive acid mesic Spolic Udorthents

22 loamy-skeletal mixed semiactive nonacid mesic Spolic Udorthents

23 loamy-skeletal mixed active acid mesic Spolic Udorthents

24 loamy-skeletal mixed semiactive nonacid mesic Spolic Udorthents

25 loamy-skeletal mixed semiactive nonacid mesic Spolic Udorthents

26 loamy-skeletal mixed semiactive nonacid mesic Spolic Udorthents

Spolic is defined as earthy soil materials that have been moved by earth moving equipment in surface mining, highway construction, and other earth-moving activities. The major difference between this proposed system and the WVU system is the taxonomic level at which spolic materials are identified. In the WVU system, spolic materials are identified at the suborder level, but Fanning and Fanning identify them at the subgroup level. Therefore, the WVU system indicates some property differences at the suborder level while Fanning and Fanning system does not. 
The third proposed method (Strain and Evans, 1994) classified disturbed soils at the order level, with suborder designations derived from the terms developed by (Fanning and Fanning, 1989). This system proposed a new order, Anthrosols, based upon some earlier work by Kosse (1988) (Table 9).

Table 9. Minesoil Soil Classification by Strain and Evans (1994) Proposed Method

\begin{tabular}{|c|c|c|c|c|}
\hline $\begin{array}{l}\text { Soil } \\
\text { Age }\end{array}$ & $\begin{array}{l}\text { Site } \\
\text { Number }\end{array}$ & & & \\
\hline$\overline{23}$ & 1 & loamy-skeletal mixed active & acid & mesic Densic Geospolans \\
\hline 23 & 2 & loamy-skeletal mixed semiactive & acid & mesic Densic Geospolans \\
\hline 23 & 3 & loamy-skeletal mixed semiactive & acid & mesic Densic Geospolans \\
\hline 23 & 4 & loamy-skeletal mixed active & acid & mesic Densic Geospolans \\
\hline 23 & 5 & loamy-skeletal mixed semiactive & nonacid & mesic Densic Geospolans \\
\hline 23 & 6 & loamy-skeletal mixed semiactive & nonacid & mesic Densic Geospolans \\
\hline 11 & 1 & loamy-skeletal mixed semiactive & nonacid & mesic Densic Geospolans \\
\hline 11 & 2 & loamy-skeletal mixed subactive & nonacid & mesic Densic Geospolans \\
\hline 11 & 3 & loamy-skeletal mixed semiactive & nonacid & mesic Densic Geospolans \\
\hline 11 & 4 & loamy-skeletal mixed semiactive & acid & mesic Densic Geospolans \\
\hline 11 & 5 & loamy-skeletal mixed semiactive & nonacid & mesic Densic Geospolans \\
\hline 11 & 6 & loamy-skeletal mixed semiactive & acid & mesic Densic Geospolans \\
\hline 7 & 1 & loamy-skeletal mixed active & nonacid & mesic Densic Geospolans \\
\hline 7 & 2 & loamy-skeletal mixed semiactive & nonacid & mesic Densic Geospolans \\
\hline 7 & 3 & loamy-skeletal mixed semiactive & nonacid & mesic Densic Geospolans \\
\hline 7 & 4 & loamy-skeletal mixed semiactive & acid & mesic Densic Geospolans \\
\hline 7 & 5 & loamy-skeletal mixed subactive & nonacid & mesic Densic Geospolans \\
\hline 7 & 6 & loamy-skeletal mixed semiactive & acid & mesic Densic Geospolans \\
\hline 2 & 1 & loamy-skeletal mixed superactive & acid & mesic Densic Geospolans \\
\hline 2 & 2 & loamy-skeletal mixed semiactive & nonacid & mesic Densic Geospolans \\
\hline 2 & 3 & loamy-skeletal mixed active & acid & mesic Densic Geospolans \\
\hline 2 & 4 & loamy-skeletal mixed semiactive & nonacid & mesic Densic Geospolans \\
\hline 2 & 5 & loamy-skeletal mixed semiactive & nonacid & mesic Densic Geospolans \\
\hline 2 & 6 & loamy-skeletal mixed semiactive & nonacid & mesic Densic Geospolans \\
\hline
\end{tabular}


If this system were used, all minesoil in this study would change from Typic Udorthents to Densic Geospolans. The term Densic is used to describe pedons that have a bulk density uncorrected for rock fragments of greater than $1.7 \mathrm{~g} \mathrm{~cm}^{-3}$ in the control section. The subgroup "Geo" refers to soils having less than $15 \mathrm{~g} / \mathrm{kg}$ of organic carbon in the control section, and the term spolan was derived from Fanning and Fanning. The term densic was coined to describe root-limiting layers such as fragipans, densipans, petrocalcic, and petrogypsic horizons. However, the term densic does not properly characterize these minesoils, because there was no evidence of root limiting layers. The higher bulk densities found in the minesoils was due to rock fragment content which ranged from 38-94\%. Rock fragment content ranged from 1-38\% for soils in the Anthrosol study. Thus, the higher bulk densities were due to rock fragment content and not compaction or other pedogenic processes. Also, Strain and Evans used an excavation method to determine the bulk density of all horizons described in each pedon. This differs from my study since an excavation method was used only on the surface horizon, and the saran-coated clod method was used on all other described horizons. The clod method is known to yield higher bulk densities than that of the excavation method, thus causing comparison of my bulk density values to Strain and Evans bulk density values to be problematic. However, even when using corrected rock fragment bulk densities some of the horizons described in my study would still fit densic (Table 10). 
Table 10. Minesoil Soil Classification by Strain and Evans (1994) Proposed Method using a Bulk Density $<2 \mathrm{~mm}$

\begin{tabular}{|c|c|c|c|c|}
\hline $\begin{array}{l}\text { Soil } \\
\text { Age }\end{array}$ & $\begin{array}{c}\text { Site } \\
\text { Number }\end{array}$ & & & \\
\hline 23 & 1 & loamy-skeletal & mixed & active $\quad$ acid mesic Typic Geospolans \\
\hline 23 & 2 & loamy-skeletal & mixed & semiactive acid mesic Typic Geospolans \\
\hline 23 & 3 & loamy-skeletal & mixed & semiactive acid mesic Typic Geospolans \\
\hline 23 & 4 & loamy-skeletal & mixed & active acid mesic Typic Geospolans \\
\hline 23 & 5 & loamy-skeletal & mixed & semiactive nonacid mesic Densic Geospolans \\
\hline 23 & 6 & loamy-skeletal & mixed & semiactive nonacid mesic Densic Geospolans \\
\hline 11 & 1 & loamy-skeletal & mixed & semiactive nonacid mesic Typic Geospolans \\
\hline 11 & 2 & loamy-skeletal & mixed & subactive nonacid mesic Typic Geospolans \\
\hline 11 & 3 & loamy-skeletal & mixed & semiactive nonacid mesic Densic Geospolans \\
\hline 11 & 4 & loamy-skeletal & mixed & semiactive acid mesic Densic Geospolans \\
\hline 11 & 5 & loamy-skeletal & mixed & semiactive nonacid mesic Typic Geospolans \\
\hline 11 & 6 & loamy-skeletal & mixed & semiactive acid mesic Typic Geospolans \\
\hline 7 & 1 & loamy-skeletal & mixed & active nonacid mesic Typic Geospolans \\
\hline 7 & 2 & loamy-skeletal & mixed & semiactive nonacid mesic Typic Geospolans \\
\hline 7 & 3 & loamy-skeletal & mixed & semiactive nonacid mesic Typic Geospolans \\
\hline 7 & 4 & loamy-skeletal & mixed & semiactive acid mesic Typic Geospolans \\
\hline 7 & 5 & loamy-skeletal & mixed & subactive nonacid mesic Typic Geospolans \\
\hline 7 & 6 & loamy-skeletal & mixed & semiactive acid mesic Typic Geospolans \\
\hline 2 & 1 & loamy-skeletal & mixed & superactive acid mesic Typic Geospolans \\
\hline 2 & 2 & loamy-skeletal & mixed & semiactive nonacid mesic Typic Geospolans \\
\hline 2 & 3 & loamy-skeletal & mixed & active acid mesic Densic Geospolans \\
\hline 2 & 4 & loamy-skeletal & mixed & semiactive nonacid mesic Densic Geospolans \\
\hline 2 & 5 & loamy-skeletal & mixed & semiactive nonacid mesic Densic Geospolans \\
\hline 2 & 6 & loamy-skeletal & mixed & semiactive nonacid mesic Typic Geospolans \\
\hline
\end{tabular}

Each of the proposed systems has some positive and negative attributes. In the Strain and Evans system, the term densic did not accurately describe the minesoils in my study since none of the minesoils showed evidence of root limiting layers. However, the subgroup "Geo" accurately described the low carbon content of my research minesoils. The system proposed by Sencindiver seemed to limit itself by classifying the soils mainly based on rock type and percent. While this system did an excellent job classifying my research minesoils, other types of human altered soils may not be classified under this system as accurately, which will be needed as the human 
population grows and is increasingly disturbing large areas of the earth. The system proposed by Fanning and Fanning described the genesis of my minesoils correctly by using the term spolic, and their system seems to incorporate a larger spectrum of human impacted soils. However, Fanning and Fanning proposed system shows little about what parent material these minesoils are forming from, which was determined by using the system proposed by Sencindiver. By knowing the parent material, a better idea of possible texture, infiltration, nutrient holding capacity, etc. could be obtained by using the system proposed by Sencindiver. 


\section{Productivity of Minesoils and Native Soils}

The soil productivity index (P.I.) associates soil and site characteristics with vertical root distribution of plants. The following P.I. model is based on the idea that a tree has a certain vertical root distribution and, under optimum soil/site conditions will produce the same proportional rooting pattern. If soil or site properties are limiting, tree rooting distribution will change, thus yielding a negative affect on the aboveground growth (Gale and Gringal, 1991).

When all minesoils, including both slope classes, were compared to the native soils, all native soils in this study had a higher productivity index (63\%) than the minesoils (Fig. 12). However, the 23 -year-old soil was only $1 \%$ from that of the native soils value. The lowest P.I. value was in the 11-year-old soil having only $42 \%$.

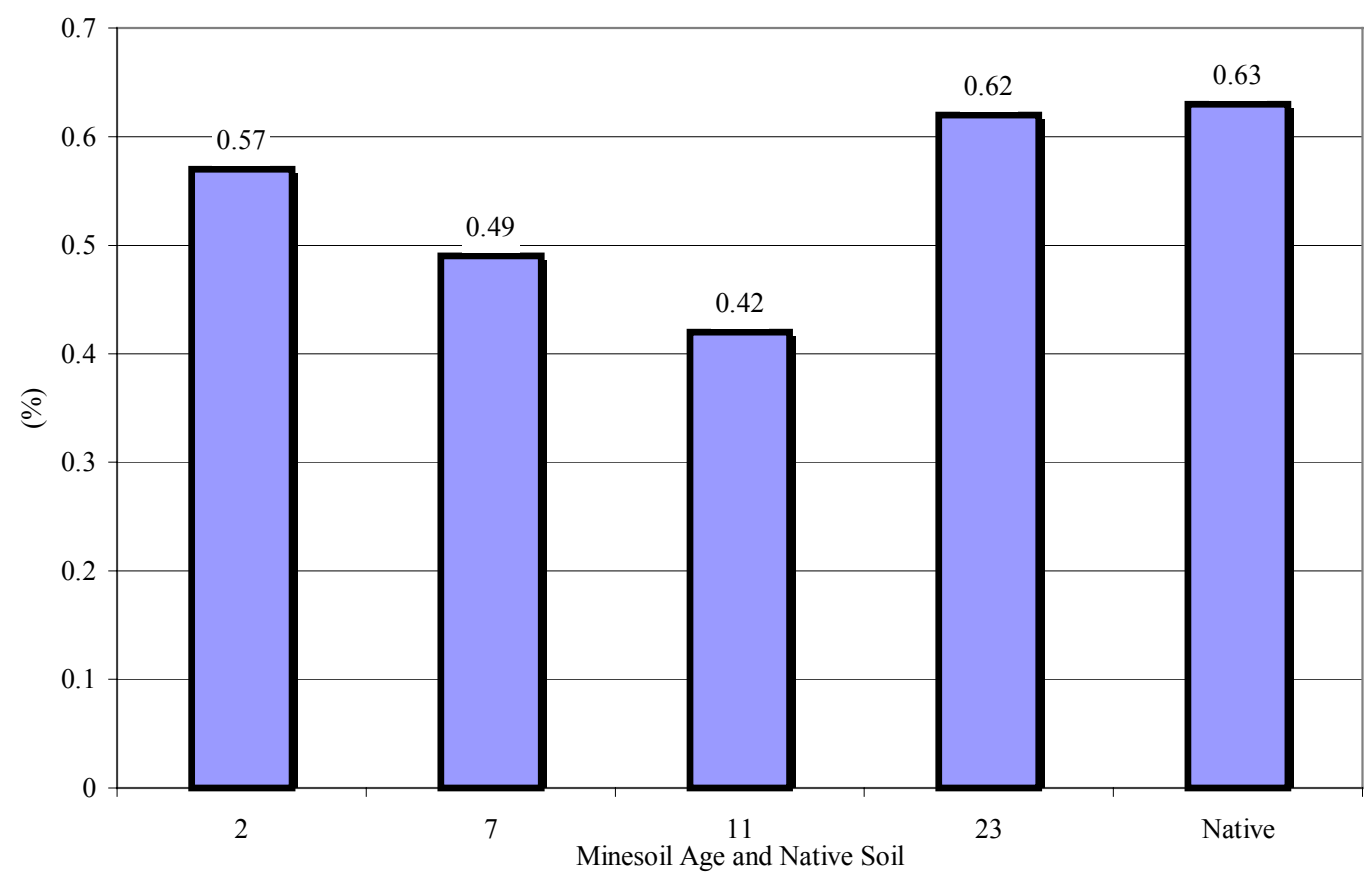

Figure 12: Average productivity index values for minesoils and native soils. 
A better representation of productivity of the research soils comes when we compare only steep slopes since the P.I. yields a greater sufficiency value for steeper slopes, since previous studies have revealed that white pine is more productive on these slopes (Fig. 13).

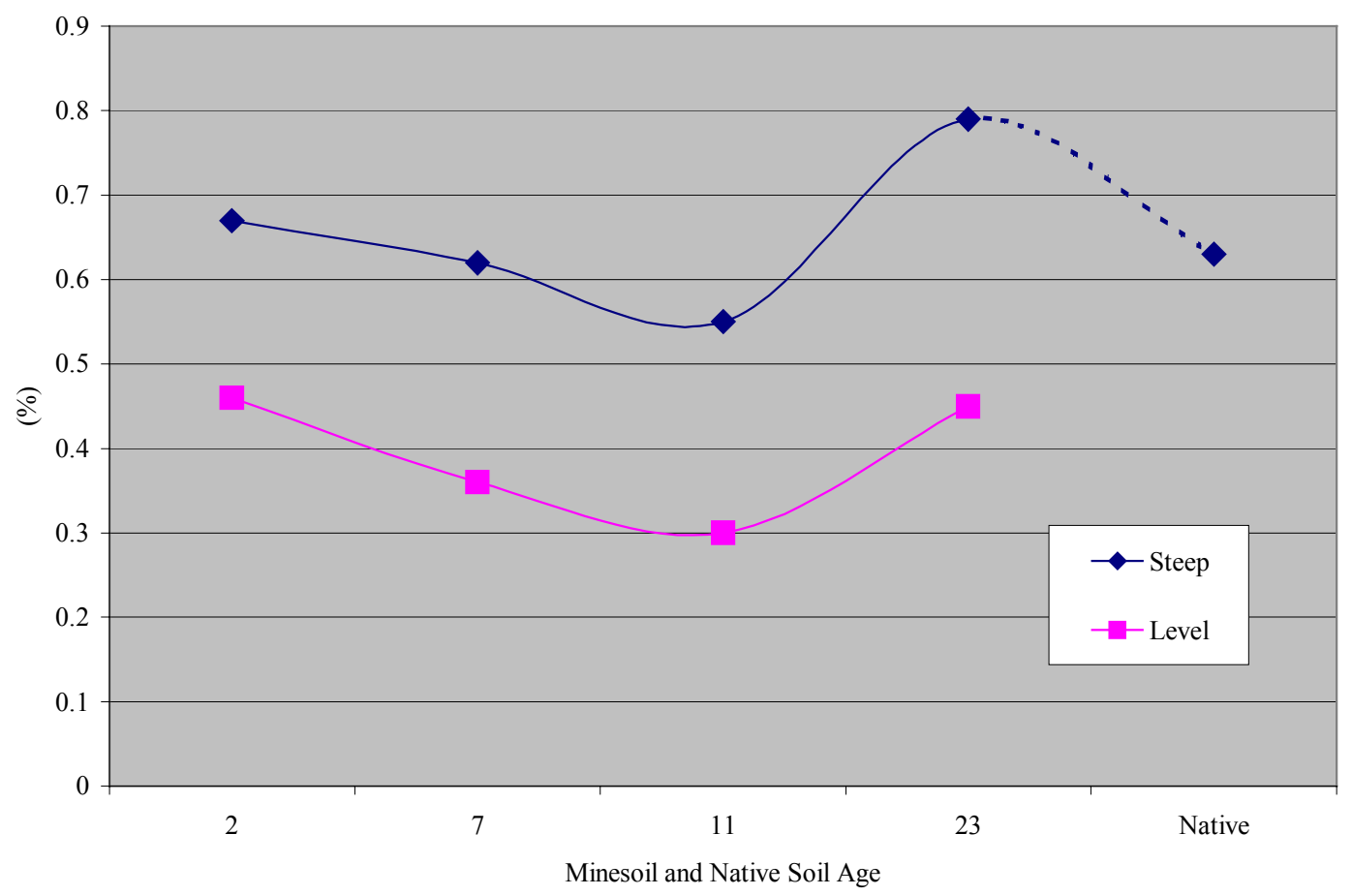

Figure 13: Average productivity index values of minesoil and native soils on steep and level slopes.

The 23-year-old minesoil sufficiency's was greater than that of the native soils. Since all native soils were on steep topography a comparison between level minesoils and native soils cannot be made. However, the highest P.I. value on level topography came from the 2-year-old minesoils with an average P.I. value of $46 \%$ (Fig. 13). A trend recognized by overall averages and when comparing the two different slope classes is that the soil tends to be highly affected in the first few years by human interaction, such as compaction, and fertilization, then as time progresses that affect diminishes. However as time increases natural processes, such as biocycling, begin to affect these minesoils. Visual inspection of these data indicate that a rebound begins around the eleventh year, and by the twenty-third year we see that the minesoil is approaching the 
productivity of the native soils on the level slopes, and surpassing the productivity of the native soils on the steeper slopes. 


\section{Summary and Conclusions}

Although minesoils in this study are very young compared to native soils of the region, they do show evidence of soil development. The data indicate that soil properties are changing with time, and that the minesoils are changing with increasing age. Thickness of A horizons, thickness of the solum (A and B horizons), and total aggregation have increased with age in the minesoils. Structure within the solum of some of the older minesoils was similar to structure at comparable depths within the native soils. Minesoil bulk density and electrical conductivity values were comparable to the native soils. Minesoil $\mathrm{pH}$ is somewhat higher than native soil $\mathrm{pH}$ because of the presence of high $\mathrm{pH}$ materials being placed at the surface during reclamation.

The native soils had higher values than the minesoils for the following properties: total $\mathrm{C}$ and $\mathrm{N}$, cation exchange capacity in the surface horizon, exchangeable Al saturation, extractable Mn, and extractable acidity. The minesoils were higher than the native soils for the following properties: total exchangeable bases, $\mathrm{pH}$, and base saturation. Extractable $\mathrm{P}$ concentrations were twice as high in the 2-yr-old minesoil as in the native soils, which were twice as high as any other minesoils. These high P levels in the 2-yr-old minesoils were undoubtedly due to fertilization at the time of revegetation. Total $\mathrm{N}$ was lower in the minesoils than the native soils. However, the minesoils did show signs of increasing total $\mathrm{N}$ levels over time.

All minesoils classified as Typic Udorthents under the current system of Soil Taxonomy (Soil Survey Staff, 1999). However, the subgroup name by no means describes the uniqueness of these minesoils. By using the current system little is identified about soil properties needed for postmine landuse. The soil is not identified as having been disturbed by human activities. 
However, by using the proposed systems of classification more information is relayed about the genesis of the minesoils. All of the proposed systems readily identified the minesoils as humanaltered soil, which can be important information for landuse in the future when surficial signs of mining may have deteriorated.

Even though all minesoils were classified as Entisols, it is highly probably that as time increases cambic horizons will develop and the minesoils will become Inceptisols. However, at the current stage in the development of the minesoils not enough time has passed to allow pedogenic processes to form the necessary characteristics needed to yield cambic horizons. Pedons 23-06 and 7-04 already have weakly developed B horizons that may fit cambic criteria in 10 's of years. Other pedons may take 10 's to 100 's of years to develop cambic horizons. Over time the interaction of the soil forming factors should develop stronger structure, promote clay movement and possibly develop argillic horizons (probably 1000's of years). Once these argillic horizons have developed, these minesoils will then be classified as Alfisols or Ultisols, depending upon base saturation. However, none of the native soils had argillic horizons, because parent material did not generate enough clay upon weathering. Due to the mining process, deep geologic disruption is common. Certain geologic layers, such as mudstone, occur throughout the overburden excavated at this site. Thus, it is highly probable that this fresh geologic material could yield enough clay to promote argillic horizon development upon weathering, eluviation, and illuviation.

Based solely on the productivity index, the minesoils could produce a minimum of $42 \%$ and a maximum of $62 \%$ of an ideal white pine crop. However, the native soils were predicted to produce only $63 \%$ of an ideal crop. As mentioned earlier, previous research by Gale et al. (1991) showed that as a measure of site quality the P.I. model performs better in younger stands than 
older. This is due to the fact that the P.I. model is based around mineral soil characteristics, and is more applicable in younger stands that have not yet accumulated thick organic layers. As stands mature their rooting habits shift from extracting nutrients from the mineral soil to an increased emphasis to the forest floor. Thus the P.I. model may be a better predictor of younger minesoil quality than of older minesoil or native soil quality. So a comparison of the native soils to the minesoils is not an accurate or fair depiction of the native soils quality since the model is designed for younger soil. The P.I. sufficiency values may be useful to identify layers that are limiting to root growth and productivity, and the extent to those limitations.

Morphological, physical, and chemical data indicate that minesoils in this study may provide adequate rooting depth and plant nutrients for grasses, legumes, and trees. As the minesoils continue to weather and develop over time, they have the potential to become as productive as or better than the original native soil. 


\section{Literature Cited}

Adamo, D.C. 1986. Properties of soils and mineral concentrations of forages on reclaimed surface mines. M.S. Thesis. West Virginia Univ. Morgantown, WV.

Ammons, J.T. 1979. Minesoil properties, root growth, and land use implications. Ph.D. diss. West Virginia Univ., Morgantown (Diss. Abstr: 40:2936B).

Ammons, J.T. and J.C. Sencindiver. 1990. Minesoil mapping at the family level using a proposed classification system. J. Soil and Water Cons. 45: 567-571.

Andrews, J.A. 1992. Soil productivity model to asses forest site quality on reclaimed surface Mines. M.S. Thesis. VA Poltech. Inst. And State Univ. Blacksburg. VA. 133p.

Barlow, J.A., and R.B. Erwin. 1974. Coal and coal mining in West Virginia. Coal-geology bulletin No. 2. Morgantown, W.V.

Barnhisel, R.I. 1977. Reclamation of surface mined coal spoils. U.S. EPA. CSRS.USDA No. D6E762. EPA 6000/7-77-093.

Barnhisel, R.I. and H.F. Massey. 1969. Chemical, mineralogical and physical properties of Eastern Kentucky acid- forming coal spoil material. Soil Sci. 108: 367-372.

Bell, J.C., L.C. Cunningham, C.T. Anthony. 1994. Morphological characteristics of Reconstructed prime farmland soils in western Pennsylvania. J. Environ. Qual. 23:515520.

Berg, W.A. W.G. Vogel. 1968 Manganese toxicity of legumes seeded in Kentucky Stripe-mine spoils. USDA For. Serv. Res. Pap Ne-119.

Berg, W.A. and W.G. Vogel. 1973. Toxicity of acid coal mine spoils to plants. p. 57-68. In R.J. Hutnik and Gdavis (ed.). Ecology and Reclamation of devastated land. Vol. 1. Gordon and Breach. New York.

Bezdicek, F. D., R.I. Papendick, and L. Rattan. 1996. Introduction: Importance of soil quality to health and sustainable land management. In Doran, J.W, and A.J. Jones (ed.) In Methods for assessing soil quality. SSSA special publication number 49.

Burger, J.A., J.E. Johnson., J.A. Andrews and J.L. Torbert. 1994. Measuring minesoil productivity for forest. p. 5-16. In proceedings of the International Land Reclamation and Mine Drainage Conference. Pittsburgh, PA.

Cardwell, D.H., R.B. Erwin, and H.P. Woodward. 1968. Geologic Map of West Virginia. Geological and Economic Survey. Morgantown, WV.

Ciolkosz, E.J., R.C. Cronce, R.L. Cunningham, and G.W. Petersen. 1985. Characteristics, genesis, and classification of Pennsylvania minesoils. Soil Sci. 139:232-238

Cline, M.G. 1977. Historical highlights in soil genesis, morphology and classification. Soil Sci. Soc Am. J. 41: 250-254. 
Cole, C.P. 1976. Overburden and minesoil properties in relation to orginal soil profiles, with special attention to subsoil structure. M.S. Thesis. West Virginia University. Morgantown, WV.

Daniels, L.W. and D.F. Amos. 1981. Chemical characteristics of some southwest Virginia minesoils. p. 261-282. In Proceedings of the 1981 Symposium on Surface Mining, Hydrology, Sedimintology, and Reclamation. Univ. of Kentucky, Lexington, KY.

Daniels, L.W. and D.F. Amos. 1982. Chemical characteristics of some southwest Virginia minesoils. p. 377-381. In Proceedings of the 1982 Symposium on Surface Mining, Hydrology, Sedimintology, and Reclamation. Univ. of Kentucky, Lexington, KY.

Dant, J.M. 1984. Greenhouse evaluation of phosphorus availability of selected West Virginia minesoils. M.S. Thesis. West Virginia Univ. Morgantown, WV.

Doran, J.W. A.J. Jones, M.A. Arshad, and J.E. Gilley. 1999. Determinants of soil quality and health. p. 17-36. In R. Lal (ed). Soil Quality and Soil Erosion. Soil and Water Conservation Society. CRC Press. Boca Raton, FL.

Doran, J.W. and T.B. Parkin. 1996. Quantitative indicators of soil quality: a minimum data set. p. 25-38. In J.W Doran and A.J. Jones (eds). Methods for Assesing Soil Quality. SSSA Spec. Publ. No. 49. Soil Sci. Soc. of Amer. Madison, WI.

Dowdy, S.M. and W. Stanley. 1991. Statistics and Research. $2^{\text {nd }}$ ed. John Wiley and Sons, Inc. New York, New York.

Down, C.G. 1975. Soil development on colliery waste tips in relation to age: II. Chemical factors. J. Aol. Ecol. 12:623-634.

Dunker, R.E., S.L. Vance, and R.G. Dormandy. 1992. Rowcrop response to high traffic vs. low traffic soil reconstruction systems. P. 11-18. In R.E. Dunkard et al. (ed.) Prime farmland reclamation. Proc. 1992 Natl. Symp. Prime Farmlands Reclamat., St. Louis, MO. 10-14 August. Dep Agron., Univ. Illinois, Urbana

Fanning, D.S. and M.C.B. Fanning. 1989. Soil morphology, genesis, and classification. John Wiley and Sons. New York, NY. 395 p.

Fleming, A.L., J.W. Schwartz, and C.D. Foy. 1974. Chemical factors controlling the adaption of weeping lovegrass and tall fescue to acid mine spoils. Agron. J. 66: 715-719.

Gale, M.R. 1987. A forest productivity index model based on soil-root distributional characteristics. Ph.D. Diss., Univ. of Minnesota, St. Paul (Diss. Abstr. 88-02395).

Gale, M.R., and D. F. Gringal. 1987. Vertical root distributions of northern tree species in relation to successional status. Can. Jour. For. Res. 17:829-834.

Gale, M.R., D.F. Gringal, and R. B. Harding. 1991 Soil productivity index: predictions of site quality for white spruce plantations. Soil Sci. Soc. Amer. Jour. 55: 1701-1708.

Gorman, J.M., J.C. Sencindiver, R.F. Keefer. And R.N. Singh. 1991. Physical properties of fly ash-treated minesoils. P. 389-402. In: Proc. Of the American Society for surface Mining and Reclamation Conference. Durango, Colorado, May 14-17, 1991.

Hearing K.C., W.L. Daniels, and J.A. Roberts. 1993. Changes in properties resulting from overburden weathering. J. Envir. Qual. 22:194-200. 
Hoover, S.L. 1994. Physical properties of two minesoil series relating to wastewater treatment potential. M.S. Thesis, West Virginia University. Morgantown, WV.

International Committee on Anthropogenic Soils (ICOMANTH). 1995. Circular Letter no. 1. Cornell University, Ithaca, NY.

Indorante, S.J. and I.J. Jansen. 1984. Perceiving and defining soils on disturbed lands. Soil Sci. Soc. Am. J. 48:1334-1337.

Indorante, S.J.,L.R. Follmer., R.D. Hammer, and P.G. Koenig. 1990. Particle-size analysis by a modified pipette procedure. Soil Sci. Soc. Am. J. 54: 560-563.

Johnson, C.D. 1992. Natural reclamation of abandoned mine land. M.S. Thesis, West Virginia University. Morgantown, WV.

Johnson, C.D. and J. Skousen. 1995. Minesoil properties of 15 abandoned mine land sites in West Virginia. J. Environ. Qual. 24: 635-643.

Karlen, D.L., M.J. Mausbach, J.W. Doran, R.G. Cline, R.F. Harris, and G.E. Schuman. 1997. Soil quality: A concept, definition, and framework for evaluation (A guest editorial).Soil Sci. Soc. Am. J. 61: 4-10.

Kemper, W.D., and R.C. Rosenau 1986. Aggregate stability and size distribution. p. 425-442. In Klute, A. (ed). Methods of Soil Analysis, Part 1: Physical and Mineralogical Methods. No. 9, Agronomy. ASA. SSSA, Madison, WI.

Kiniry, L.N., C.L. Scrivner, and M.E. Keener. 1983. A soil productivity index based upon predictied water depletion and root growth. Univ. of Missouri Agr. Exp. Sta. Res. Bull. 1051, Columbia. MO. 25 pp.

Kosse, A. 1988. Anthrosols: proposal for a new order. p. 260. Agron. Abstracts.Amer. Soc. of Agron., Madison, WI.

Limstrom, G.A. 1960. Extent, character, and forestation possibilities of land stripped for coal in the central States. USDA Forest Service Central States For. Exp. Sta. Tech. Paper No. 109. $79 \mathrm{pp}$.

Lutz, H.J., J.B Ely, Jr., and S. Little, Jr. 1937. The influence of soil profile horizons on root distribution of white pine (Pinus strobus L.) Yale Univ. School of For. Bull. No. 44. 113 pp.

Massey, H.F. 1972. pH and soluable $\mathrm{Cu}, \mathrm{Ni}$, and $\mathrm{Zn}$ in eastern Kentucky coal mine spoil materials. Soil Sci. 114(3): 217-221.

Massey, H.F. and R.I. Barnhiesel. 1972. Copper, nickel, and zinc released from acid coal mine spoil materials of eastern Kentucky. Soil Sci. 113(3): 207-212.

Mays, D.A., and G.W. Bengston. 1978. Lime and fertilizer use in land reclamation in humid regions. p. 307-328. In F.W. Schaller and P. Sutton (ed.) Reclamation of drastically disturbed lands. ASA. Madison. WI.

McSweeney, K. and I.J. Jansen. 1984. Soil structure and associated rooting behavior in minesoils. Soil Sci. Soc. Am. J. 48:607-612. 
Omodt, H.W., F.W. Schroer, and D.D. Patterson. 1975. The properties of important agricultural soils as criteria for mine land reclamation. North Dakota State University Agric. Exp. Sta. Bull. 492. Fargo, ND.

Pederson, T.A., A.S. Rogowski, Jr. 1978. Comparison of morphological and chemical Characteristics of some soils and minesoils. Reclamation Review. 1: 145-156.

Pederson, T.A., A.S. Rogowski, and R Pennock, Jr. 1980. Physical characteristics of some minesoils. Soil Sci. Soc. Am. J. 44:321-328.

Pierce, F.J., W.E. Larson, R.H. Dowdy, and W.A.P. Grahm. 1983. Productivity of soils: Assessing long-term changes due to erosion. Jour. Soil and Water Conserv. 38: 39-44.

Plass, W.T, and W.G. Vogel. 1973. Chemical properties and particle-size distrubution of 39 surface-minespoils in southern West Virginia. USDA Forest Res. Paper NE 276.

Rich, C.I., and S.S. Obenshain. 1955. Chemical and clay mineral properties of a red- yellow podzolic soil derived from muscovite schist. Soil Sci. Soc. Am. Proc. 19:334-339.

Richards, L.A. (editor). 1954. Diagnosis and improvement of saline and alkali soils.USDA Agric. Handbook 60.

Roberts, J.A., W.L. Daniels, J.C. Bell, and J.A. Burger. 1988a. Early stages of mine soil genesis in a southwest Virginia spoil lithosequence. Soil Sci. Soc. Am. J. 52:716-723.

Roberts, J.A. , W.L. Daniels, J.C. Bell, and J.A. Burger. 1988b. Early stages of mine soil genesis as affected by topsoiling and organic amendments. Soil Sci. Soc. Amer. J. 52:730-738.

Sarrantonio, M., J.W. Doran, M.A. Liebeg, and J.J. Halvorson. 1996. On-farm assessment of soil quality and health. .p. 83-105. In J. W. Doran and A.J. Jones (ed.) Methods for Assessing Soil Quality. SSSA Spec. Publ. 49. SSSA, Madison,WI.

Schafer, W.M. 1979. Minesoil resources in the Northern Great Plains: characterization, evaluation and potential. Ph.D thesis . Montana State Univ. pp. 203.

Schafer, W.M., G.A. Nielsen, and W.D. Nettleton. 1980. Minesoil genesis and morphology in a spoil chronosequence in Montana. Soil Sci Soc. Am. J. 44:802-807.

Schroer, F.W. 1978. Characterization of coal overburden and strip mine spoils in North Dakota. North Dakota Research Report No. 68. North Dakota Sate University, Fargo, ND. 17 pp. plus appendices.

Sencindiver, J.C. 1977. Classification and genesis of minesoils. Ph.D. Diss.West Virginia University. Morgantown, WV.

Sencindiver, J.C. and J.T., Ammons. Minesoil genesis and classification. In Reclamation of Drastically Disturbed Lands. $2^{\text {nd }}$ ed. ASA, CSSA, SSSA. Madison, WI. In press.

Sencindiver, J.C. and J.T., Ammons, and C.H. Delp. 1978. Classification of Minesoils- a proposed suborder. $\mathrm{p} 230$. In Abstracts of the $11^{\text {th }}$ Int. Congr. Soil Sci.

(Edmonton,Canada).

Short, J.R., D.S. Fanning, M.S. McIntosh, J.E. Foss, and J.C. Patterson. 1986. Soils of the mall in Washington, DC: II. genesis, classification, and mapping. Soil Sci. Soc. Am J. 50: 705710. 
Silburn , D.M. and F.R. Crow. 1984. Soil properties of surface mined land. Trans. ASAE. 27(3):827-832.

Singh, R.N., W.E. Grube, Jr., R.M. Smith, and R.F. Keefer. 1982. Relation of pyritic sandstone weathering to soil and minesoil properties. p. 193-203. In J.A. Kittrick et al. (ed.) Acid sulfate weathering. SSSA Spec. Publ. 10. SSSA, Madison, WI.

Skousen, J., J. Sencindiver., K.Owens., and S. Hoover. 1998. Physical properties of minesoils in West Virginia and their influence on wastewater treatment. J. Environ. Qual. 24: 635643.

Skousen, J., P. Ziemkiewicz, and C. Venable. 1999. Evaluation of tree growth on surface mined lands in southeastern West Virginia. Green Lands. 29(1):43-55

Smith, R.M. and A.A. Sobek. 1978. Physical and chemical properties of overburden, spoils, wastes, and new soils. p. 149-172. In F.W. Schaller and P. Sutton (eds.). Reclamation of Drastically Disturbed Lands. American Society of Agronomy. Madison, WI.

Smith, R.M., and E. H. Tyron, and E.H. Tyner. 1971. Soil development on mine spoil. W. Va. Agric. Exp. Stn. Bull. 604T.

Sobek, A.A., W.A. Schuller, J.R. Freeman, and R.M. Smith. 1978. Field and laboratory methods applicable to overburdens and minesoils. EPA-600/2-78-054. U.S. Government Printing office, Washington, DC.

Soil Survey Division Staff. 1993. Soil Survey Manuel. USDA Handbook. No. 18. U.S. Gov. Print. Office, Washington, D.C.

Soil Survey Staff. 1996. Soil survey laboratory methods manual. Soil Survey Investigations Report No. 42. Version 3.0 National Soil Survey Center, Lincoln, NE.

Soil Survey Staff. 1975. Soil Taxonomy: a basic system of classification for making and interpreting soil surveys. Agric Handbook No. 436. USDA-SCS. U.S. Govt Printing Office, Washington D.C.

Soil Survey Staff. 1999. Soil Taxonomy: a basic system of classification for making and interpreting soil surveys. Agric Handbook No. 436. USDA-SCS. U.S. Govt Printing Office, Washington D.C.

Soil Survey Staff. 1998. Keys to Soil Taxonomy. Eighth Edition. USDA Natural Resources Conservation Service. Washington, D.C.

Storie, R.E. 1933. An index for rating the agricultural value of soils. Univ. California Agric.Exp. Stn. Bull. 556.

Strain, M.R. and C.V. Evans. 1994. Map unit development for sand-and gravel-pit soils in New Hampshire. Soil Sci. Soc. Am. J. 58:147-155.

Torbert, J.L., J.A. Burger., J.E. Johnson. and J.A. Andrews. Final Report. 1994. Indices for indirect estimates of productivity of tree crops. OSM Cooperative Agreement GR996511. College of Forestry and Wildlife Resources. Virginia Polytechnic Institute and State University.

Thomas, J.T. 1987. Characterization and classification of minesoils in central West Vurginia. M.S. Thesis, West Virginia University. Morgantown, WV. 
Thomas, K.A., J.C. Sencindiver.,J.G.Skousen. and J.M.Gorman. 2000. Soil development on a mountaintop removal coal mine in southern West Virginia. p. 547-556. In Proc. of the Annual National Meeting of the Amer. Soc.for Surface Mining and Reclamation.11-15 June 2000. Tampa, FL.

Thurman, N.C. and J.C. Sencindiver. 1986. Properties, classification, and interpretations of minesoils at two sites in West Virginia. Soil Sci. Soc. Amer. J. 50:181-185.

Varela, C.C. Vazquez, M.V. Gonzalez-Sangregio, M.C. Leiros and F. Gil-Sotres. 1993. Chemical and physical properties of opencast lignite minesoils. Soil Sci. 156(3): 193-203.

Vandevender, J.C. and J.C. Sencindiver. 1982. The effects of three forms of nitrogen fertilizer, phosphorus and hydrated lime on abandoned mine land reclamation. p. 447-502. In D.H. Graves (ed.) Proc. 1982 Sympossium on Surface Mining, Hydrology, Sedimentology, and Reclamation. Univ. of Kentucky, Lexington, Ky.

Wells, C.G. and J.R. Jorgensen. 1975. Nutrient cycling in loblolly pine plantations. In:B. Bernier and C.H. Winget (eds.), Forest soils and land management. Quebec: Laval University Press. Quebec Can. p.137-157.

Wilson, H.A. 1957. Effect of vegetation upon aggregation in strip mine soils. Soil Sci. Soc. Amer. Proc. 21: 637-640.

Wolf, A.M., and D.E. Baker. 1985. Comparisons of soil test phosphorus by olsen, bray p1, mehlich I and mehlich III methods. Commun. In Soil Sci. Plant Anal., 16(5):467-484.

Wolf, B.L., L.D. Emerson, and J.C. Sencindiver. 1990. Forage production on a minesoil in southern West Virginia. In Proc. of the 1990 Mining and Reclamation Conference and Exhibition. p.121-125. Vol. I. West Virginia University, Morgantown, WV.

Wolf, B.L.1994. Soil survey of Boone County, West Virginia. USDA Soil Conservation Service. U.S. Gov. Printing office. Washington. D.C.

Younos, T.M. and V.O. Shanholtz. 1980. Soil texture and hydraulic properties of post-mining soil as related to the pre-mining soil horizons. p. 153-157. In: Symp. On Surf. Min. Hyd., Sed., and Recl. Univ. of Kentucky. Lexington, KY. 
Appendices 
Appendix A

Soil Profile Descriptions 
Location-ARCH Coal DAL-TEX Mine, Logan County, WV, N 37 56' 24”, W 81 51' 17’, Stop Number

Native 1. (Described north up hill side of the pit)

Vegetation-Woodland-Sugar Maple, Sassafras, Hickory

Parent Material- Shale

Elevation-560 meters

Slope- Steep

Aspect-South

Soil type-Berks

Described by; J. Sencindiver, July 22, 1999.

Oi-4 to 0 centimeters; leaf and twig litter.

A-0 to 9 centimeters; very dark brown (10YR 2/2), silt loam; moderate fine granular structure; very friable; many very fine to coarse roots; 5 percent sandstone gravel; very strongly acid; clear wavy boundary.

BA-9 to 8 centimeters; dark grayish brown (10YR 4/2), silt loam; weak medium subangular blocky structure breaking to weak medium granular structure; very friable; many fine to coarse roots; 10 percent sandstone gravel; very strongly acid; clear wavy boundary.

Bw1-18 to 43 centimeters; light yellowish brown (10YR 6/4), silt loam; moderate medium and coarse subangular blocky structure; friable; common fine to medium roots; 25 percent shale channers; extremely acid; gradual wavy boundary. (Layer of sandstone at the bottom of this horizon)

Bw2 - 43 to 67 centimeters; yellowish brown (10YR 5/6), silt loam; moderate medium and fine subangular blocky structure; friable; few fine to medium roots; 40 percent shale gravel and channers; very strongly acid; abrupt broken boundary. (east side of the profile-R begins at approximately 50 centimeters; west side of pit is deeper soil with redox concentrations and depletions beginning at 50 centimeters; east side of pit has greater then 35 percent rock fragments in every horizon)

$\mathbf{R}-67$ to 100 centimeters; shale. 
Location-ARCH Coal DAL-TEX Mine, Logan County, WV, N 37 56' 25”, W 81 51' 14”, stop number

Native 2.

Vegetation- Sassafras, Red Maple, Black Oak, Black Gum, Chestnut Oak, Greenbrier Parent Material-Sandstone

Elavation-566 meters

Slope-Steep

Aspect-South

Soil type-Matewan

Described by; J Sencindiver, July 22, 1999.

Oi-5 to 0 centimeters; leaf and twig litter

$\mathbf{O a}-0$ to 2 centimeters; decomposed organic matter.

A/E - 2 to 5 centimeters; very dark gray (10YR 3/1) and dark grayish brown(10YR 4/2), sandy loam; weak fine granular structure; very friable; many very fine to medium roots; 20 percent sandstone gravel and channers; extremely acid; abrupt wavy boundary.

BA - 5 to 23 centimeters; yellowish brown (10YR 5/6), sandy loam; weak fine subangular blocky structure and weak fine granular (almost strong granular)structure; very friable (loose); many fine to coarse roots; 40 percent sandstone channers; very strongly acid; clear wavy boundary.

Bw-23 to 59 centimeters; brownish yellow (10YR 6/6), sandy loam; weak medium subangular blocky structure; friable; common fine to very coarse roots; 45 percent sandstone channers; very strongly acid; gradual wavy boundary.

BC - 59 to 88 centimeters; brownish yellow (10YR 6/6), sandy loam; weak medium and coarse subangular blocky structure; friable; common fine to very coarse roots; 55 percent sandstone channers; very strongly acid; abrupt wavy boundary.

$\mathbf{R}-88$ to $107+$ centimeters; sandstone fractured; few roots between fractures. 
Location- 0.4 miles south of the intersection of Schoolhouse Fork and Garland Fork, Logan, WV N 37 50' 12", W 81 48' 45" stop number

Native 3.

Vegetation- Wooded area

Parent Material- Course to medium textured colluvium

Elevation- 563 meters

Slope- Extremely Steep

Aspect- South

Soil type-Highsplint

Described by; R Pate, Nov 1999

Oi- 0 to 1 centimeters; slightly decomposed organic matter

A- 1 to 8 centimeters; very dark grayish brown (10YR 3/2), silt loam; moderate medium granular structure; very friable; many very fine to fine roots; 20 percent rock fragments; moderately acid; slightly acid; clear wavy boundary.

BA- 8 to 15 centimeters; yellowish brown (10YR 5/4) silt loam; weak medium subangular blocky structure; friable; many very fine to course roots; 20 percent rock fragments; strongly acid; strongly acid; clear wavy boundary.

Bw1- 15 to 76 centimeters; strong brown ( 7.5 YR 5/6) loam; weak medium subangular blocky structure; friable; common medium to fine roots; 35 percent rock fragments; strongly acid; very strongly acid; clear wavy boundary.

Bw2- 76 to 104 centimeters; strong brown ( 7.5 YR 5/6) loam; weak coarse subangular blocky structure; friable; common medium to fine roots; 45 percent rock fragments; very strongly acid; clear wavy boundary.

BC- 104 to 135 centimeters; yellowish brown (10 YR 5/6) loam; weak course subangular blocky structure; firm; few medium course roots; 65 percent rock fragments; very strongly acid.

C- 135 to 165 centimeters; yellowish brown (10YR 5/6) loam; massive; firm; few medium to course roots; 80 percent rock fragments; strongly acid. 
Location- ARCH Coal DAL-TEX Mine, Logan County, WV, N 37 53' 48”, W 81 51'20”, Stop Number

Minesoil 23-1

Vegetation- Sericea Lespdeza, Blackberry, Red Maple, Black Locust, Multiflora rose Parent Material- Shale, sandstone, siltstone, coal, and mudstone

Elevation-490 meters

Slope-Nearly Level

Soil type- Minesoil

Described by; J Sencindiver, August 9, 1999.

$\mathbf{O i}-0$ to 2 centimeters.

Oe -2 to 3 centimeters; abrupt wavy boundary.

A-3 to 7 centimeters; (2.5Y 5/3), silt loam; moderate fine subangular blocky structure and moderate fine to medium granular structure; friable; common very fine to coarse roots; 20 percent gravel sandstone; extremely acid; clear wavy boundary.

AC - 7 to 16 centimeters; (2.5Y 5/3), yellowish brown (10YR 5/6), light brownish gray (10YR $6 / 2$ ), (N 2.5/0), loam; weak medium and coarse subangular blocky structure; friable; common very fine to coarse roots; 30 percent channers( 5 percent carbolith, 10 percent mudstone, 85 percent sandstone); very strongly acid; clear wavy boundary.

C-16-65 centimeters; strong brown (7.5YR 5/8), yellowish brown (10YR 5/6), pale yellow (2.5Y 7/4), light brownish gray (10YR 6/2), (N 2.5/0), silty clay loam; massive; friable; few very fine to fine roots; 35 percent channers ( 20 percent carbolith, 40 percent mudstone, 40 percent sandstone); very strongly acid; abrupt wavy boundary.

$\mathbf{2 C r}-65$ to 79 centimeters; gray shale and mudstone.

$2 \mathbf{R}$-sandstone. 
Location-ARCH Coal DAL-TEX Mine, Logan County, WV, N 37 53' 42”, W 81 51' 27”, Stop Number

Minesoil 23-2. (described north side of the pit)

Vegetation-Sericea Lespedeza, Tall Fescue, Black Locust, Black Berry, Wild Grape, Red Maple Parent Material- Sandstone, and small amounts of siltstone, shale, mudstone, and coal Elevation-502 meters

Slope-Steep

Aspect-South

Soil type-Minesoil

Described By; J Sencindiver, August 9, 1999.

$\mathbf{O i}-0$ to 3 centimeters.

Oe -3 to 6 centimeters; abrupt wavy boundary.

A--6 to 13 centimeters; dark grayish brown (10YR 4/2) and brown (10YR 5/3), loam; weak medium subangular blocky structure breaking to weak fine and medium granular; friable; many very fine to medium roots; 40 percent channers (10 percent carbolith, 20 percent mudstone, 70 percent sandstone); very strongly acid; clear wavy boundary.

AC - 13 to 31 centimeters; dark grayish brown (10YR 4/2), loam; weak and moderate coarse subangular blocky structure; friable; few very fine to medium roots; 50 percent channers (10 percent carbolith, 20 percent mudstone, 70 percent sandstone); very strongly acid; ar wavy boundary.

C/B-31 to 75 centimeters; (2.5Y 5/3), sandy loam; 80 percent massive, 20 percent weak fine subangular blocky structure around roots; very friable; common very fine to medium roots; 65 percent channers ( 5 percent carbolith, 95 percent sandstone); very strongly acid; gradual wavy boundary.

C-75 to $105+$ centimeters; grayish brown ( $2.5 \mathrm{Y}$ 5/2), sandy loam; massive; very friable; few very fine to medium roots; 75 percent sandstone channers; very strongly acid. 
Location-ARCH Coal DAL-TEX Mine, Logan County, WV, N 37 53' 40”, W 81 51' 32”, Stop Number

Minesoil 23-3. (Described north side of the pit between large sandstone boulders)

Vegetation-Sericea Lespedeza, Blackberry, Red Maple, Black Locust, Autumn Olive, Tall Fescue, Orchard Grass, Poison Ivy, Iron weed, Multiflora Rose.

Parent Material- Shale, sandstone, siltstone, coal, and mudstone

Elevation- 483 meters

Slope -3 percent

Soil type-Minesoil

Described by; J. Sencindiver, August 9, 1999.

$\mathbf{O} \mathbf{i}-0$ to 1 centimeters; leaf and stem litter.

Oe -1 to 5 centimeters; partially decomposed leaf and stem litter; abrupt wavy boundary

A-5 to 12 centimeters; dark grayish brown (10YR 4/2), loam; moderate medium subangular blocky structure breaking to weak fine and medium subangular blocky structure; friable; reaction 6.5; many very fine to medium roots; 35 percent channers ( 15 percent mudstone, 15 percent carbolith, 70 percent sandstone);strongly acid; clear wavy boundary.

AC - 12 to 30 centimeters; very dark grayish brown (10YR 3/2), loam; weak coarse sub angular blocky structure breaking to weak medium subangular blocky structure; friable; reaction 6.0; common very fine to medium roots; 50 percent channers ( 80 percent sandstone, 10 percent mudstone, 10 percent carbolith); strongly acid; clear wavy boundary.

C1-30 to 87 centimeters; (N 3/0), common fine distinct yellowish brown (10YR 5/8) mottles, loam; massive; friable; few very fine to fine roots in matrix but roots concentrated and matted along rock fragments; 80 percent channers and gravel ( 40 percent carbolith, 30 percent mudstone, 30 percent sandstone); extremely acid; clear wavy boundary.

C2 - 87 to 115+ centimeters; brown to dark brown (10YR 4/3), many fine strong brown (7.5YR 4/6), yellowish brown (10YR 5/8), (N 2.5/0), and very pale brown (10 YR 7/4) mottles, loam (with pockets 3 to 5 centimeters of reddish yellow (5YR 6/8) loamy sand); massive; friable; 40 percent channers ( 70 percent sandstone, 15 percent carbolith, 15 percent mudstone); extremely acid. 
Location-ARCH Coal DAL-TEX Mine, Logan County, WV, N 37 53' 41”, W 81 51' 33”, Stop Number

Minesoil 23-4. (Described west side of the pit)

Vegetation-Sericea Lespedeza, Multiflora Rose, Black Locust, Red Maple, Crown vetch, Black Berry

Parent Material- Sandstone, and small amounts of siltstone, shale, mudstone, and coal

Elevation- 480 meters

Slope- Steep

Aspect-South

Soil type-Minesoil

Described by; J. Sencindiver, August 9,1999.

$\mathbf{O} \mathbf{i}-0$ to 1 centimeters; leaf and stem litter.

Oe -1 to 4 centimeters; partially decomposed leaf and stem litter; abrupt wavy boundary.

A-4 to 12 centimeters; yellowish brown (10YR 5/4), loam; moderate fine to medium granular structure; very friable; many very fine to very coarse roots; 30 percent channers $(90$ percent sandstone, 10 percent mudstone); extremely acid; abrupt wavy boundary.

AC - 12 to 38 centimeters; yellowish brown (10YR 5/6 and 10YR 5/4), Discontinuous black (10YR 2/1) layers up to 4 centimeters thick, sandy loam; weak medium to coarse subangular blocky structure; friable; common very fine to very coarse roots; 60 percent channers ( 90 percent sandstone, 5 percent carbolith, 5 percent mudstone; very strongly acid; gradual wavy boundary.

C-38 to 69 centimeters; yellowish brown (10YR 5/6 and 10YR 5/4), sandy loam; massive; friable; reaction 5.0; few very fine to very coarse roots; 45 percent channers (90 percent sandstone, 5 percent carbolith, 5 percent mudstone); strongly acid; gradual wavy boundary.

C/B-69 to $150+$ centimeters; yellowish brown (10YR 5/4 and 10YR 5/6) and dark yellowish brown (10YR4/4), Discontinuous dark gray (10YR 4/1) 4 centimeter pockets and layers, sandy loam with pockets of loam; massive structure with 25 percent weak medium and fine subangular blocky structure primarily around roots; friable; reaction 6.0; common very fine to coarse roots; 50 percent channers ( 80 percent sandstone, 10 percent carbolith, 10 percent mudstone); strongly acid. 
Location-ARCH Coal DAL-TEX Mine, Logan County, WV, N 37 53' 40”, W 81 51' 33”, Stop Number

Minesoil 23-5. (described east side of the pit)

Vegetation-Red Maple, Black Locust, Iron Weed, Blackberry, Sericea Lespedeza, and Tall Fescue

Parent Material- Sandstone, and small amounts of shale, siltstone, mudstone and coal

Elevation-486 meters

Slope-nearly Level

Soil type-Minesoil

Described by J. Sencindiver, August 9, 1999.

Oi- 0 to 1 centimeters; leaf and stem litter.

Oe -1 to 3 centimeters; partially decomposed litter; abrupt wavy boundary.

A-3 to 8 centimeters; brown to dark brown (10YR 4/3), sandy loam; weak fine granular structure; very friable; 4.8 reaction; many very fine to medium roots; 30 percent channers; strongly acid; clear wavy boundary.

AC - 8 to 29 centimeters; brown to dark brown (10YR 4/3), sandy loam; weak medium subangular blocky structure and moderate structure around roots; friable; 4.8; many very fine to medium roots; 50 percent channers; strongly acid; clear wavy boundary.

C1 -29 to 66 centimeters; yellowish brown (10YR 5/4), sandy loam with pockets of silty clay loam associated with mine soils; massive; friable; 7.0; few very fine to medium roots; 60 percent channers (80 percent sandstone, 15 percent mudstone; 5 percent carbolith); neutral; gradual wavy boundary.

C2 - 66+ centimeters; fragmented large boulders. (backhoe could dig no further) 
Location-ARCH Coal DAL-TEX Mine, Logan County, WV, N 37 53' 40”, W 81 51' 33”, Stop Number

Minesoil 23-5. (Described west side of the pit)

Vegetation-Red Maple, Black Locust, Iron Weed, Blackberry, Sericea Lespedeza, and Tall Fescue

Parent Material- Sandstone, and small amounts of shale, siltstone, mudstone and coal

Elevation-486 meters

Slope-Nearly Level

Soil type-Minesoil

Described by J. Sencindiver, August 9, 1999.

Oe -0 to 3 centimeters; partially decomposed litter.

A-3 to 8 centimeters; dark brown (10YR 3/3), sandy loam; moderate fine granular structure; very friable; 6.2; many very fine to medium roots; 30 percent gravel/channers ( 95 percent sandstone, 5 percent carbolith); strongly acid; clear wavy boundary..

AC -8 to 26 centimeters; dark gray (10YR 4/1) and dark grayish brown (10YR 4/2), sandy loam; weak medium subangular blocky structure and weak medium granular structure; friable; 6.0; many very fine to medium roots; 50 percent channers ( 95 percent sandstone, 5 percent carbolith); strongly acid; clear wavy boundary.

C1-26 to 61 centimeter; dark grayish brown (10YR 4/2), sandy loam; massive; friable; 8.0; few very fine to fine roots; 80 percent channers ( 95 percent sandstone, 5 percent carbolith); neutral; gradual wavy boundary.

C2 - 61+ centimeters; fragmental; large sandstone boulders with large voids. (could not dig beyond this point) 
Location-ARCH Coal DAL-TEX Mine, Logan County, WV, N 37 53' 41”, W 81 51' 34”, Stop Number

Minesoil 23-6. (described west side of the pit)

Vegetation-Autumn Olive, Black Locust, Crown Vetch, Black Berry, Sericea Lespedeza, and Tall Fescue, Parnicum, and Poke Berry.

Parent Material- Sandstone, and small amounts of shale, siltstone, mudstone and coal

Elevation- 495 meters

Slope-Steep

Aspect-South

Soil type-Minesoil

Described by J. Sencindiver, August 9, 1999.

Oi--0 to 2 centimeters; leaf and stem litter.

Oe -2 to 5 centimeters; partially decomposed litter; abrupt wavy boundary.

A-5 to 11 centimeters; (2.5Y 5/3), loam; weak fine and medium subangular blocky structure breaking to weak medium granular; friable; many very fine to medium roots; 30 percent channers (60 percent sandstone, 30 percent conglomerate; 10 percent mudstone); very strongly acid; clear wavy boundary.

Bw-11 to 26 centimeters; brown (10YR 53), loam; common fine and medium yellowish brown (10YR 5/8) and very dark gray (10YR 3/1) mottles; weak medium and coarse subangular blocky structure; friable; common very fine to coarse roots; 40 percent channers ( 60 percent sandstone, 30 percent conglomerate, 5 percent mudstone, 5 percent carbolith); very strongly acid; clear wavy boundary.

C -26 to $120+$ centimeters; brown to dark brown (10YR 4/3), loam; common fine and medium yellowish brown (10YR 5/6), strong brown (7.5YR 5/6), and very dark gray (10YR 3/1) mottles; massive; friable; few fine to medium roots; 50 percent channers ( 70 percent sandstone, 20 percent mudstone, 10 percent carbolith); moderately acid. (water in the bottom of the pit) 
Location-ARCH Coal DAL-TEX Mine, Logan County, WV, N 37 54' 56”, W 81 51' 21”, Stop Number

Minesoil11-01.

Vegetation-Orchard grass, Birdsfoot Trefoil, Sericea Lespedeza, Tall Fescue, and Black Locust Parent Material- Sandstone, and small amounts of shale, siltstone, mudstone and coal Elevation-432 meters

Slope-Nearly Level

Soil type-Minesoil

Described by J. Sencindiver, July 20, 1999.

Oe -0 to 3 centimeters, dark grayish brown (10YR 4/2); friable; many very to fine roots; abrupt smooth boundary; root material present.

A-3 to 11 centimeters; (2.5Y 5/3), sandy loam; weak medium subangular block structure breaking to moderate medium granular at the roots; friable; many very fine to fine roots; 25 percent sandstone, 1 percent carbolith; very strongly acid; abrupt wavy boundary.

AC -11 to 37 centimeters; (2.5Y 5/1), loam; weak medium and coarse subangular blocky structure breaking to moderate medium and fine subangular blocky structure at the roots; friable; 40 percent channers, 75 percent sandstone, 15 percent carbolith, 10 percent mudstone; moderately acid; clear wavy boundary.

C1 -37 to 89 centimeters; brown (10YR 5/3), sandy loam nearly loamy sand; massive; friable; few very fine to fine roots; 70 percent flags ( 90 percent sandstone, 10 percent carbolith); slightly acid; gradual wavy boundary.

C2 - 89 to 160+ centimeters; (2.5Y 5/3), loam; massive; friable; very few very fine to fine roots; 70 percent flags and stones (80 percent sandstone, 10 percent carbolith, 10 percent mudstone; slightly acid.

Sandstone in all horizons displayed low and high chroma 
Location-ARCH Coal DAL-TEX Mine, Logan County, WV, N 37 54' 56”, W 81 51' 21”, Stop Number

Minesoil 11-2

Vegetation-Sericea Lespedeza, Birdsfoot Treefoil, Orchard Grass, Tall Fescue, and Black Locust Parent Material- Sandstone, and small amounts of shale, siltstone, mudstone and coal Elevation-429 meters

Slope-Steep

Aspect-South

Soil type-Minesoil

Described by J. Sencindiver, July 20, 1999.

Oi-0 to 3 centimeters; dark brown (10YR 3/3); many fine to very fine roots; abrupt wavy boundary; root material present

A-3 to 18 centimeters; dark yellowish brown (10YR 4/6), loam; weak medium subangular blocky structure with moderate fine granular structure around the roots; friable; common fine, very fine, and few medium roots; 30 percent channers; very strongly acid; clear wavy boundary.

AC - 18 to 41 centimeters; dark brown (10YR 4/6), loam; massive with weak fine medium subangular blocky structure around roots; friable; few very fine to medium roots; 35 percent channers, 1 percent carbolith; very strongly acid; abrupt wavy boundary.

C1 -41 to 75 centimeters; dark grayish brown (10YR 4/2), sandy loam; massive with fine subangular blocky structure around roots; very friable; common very fine to medium roots (pockets of matted roots); 70 percent channers (90 percent sandstone, 5 percent mudstone, 5 percent carbolith); strongly acid; gradual wavy boundary. (less compacted than above horizon and horizon material loose)

C2 - 75 to 125 + centimeters; dark grayish brown (10YR 4/2), sandy loam; massive with weak fine subangular blocky structure around roots; very friable; few very fine to fine roots; 70 percent flaggy with few stones ( 90 percent sandstone, 5 percent mudstone, 5 percent carbolith); moderately acid.

Rock fragments disordered in all horizons. 
Location-ARCH Coal Spruce Mine, Logan County, WV, N 37 54' 58”, W 81 51' 11”, Stop Number

Minesoil 11-3

Vegetation-Sericea Lespedeza, Birdsfoot Treefoil, Orchard Grass, and Tall Fescue Parent Material- Sandstone, and small amounts of shale, siltstone, mudstone and coal Elevation- 438 meters

Slope-Nearly Level

Soil type-Minesoil

Described by J. Sencindiver, July 20, 1999.

A--0 to 3 centimeters; dark grayish brown (10YR 4/2), sandy loam; weak and moderate fine granular structure; very friable; many fine to very fine roots; 20 percent sandstone carbolith channers; strongly acid; abrupt wavy boundary.

AC - 3 to 16 centimeters; dark gray (10YR 4/1), channery sandy loam; weak medium subangular blocky structure; common fine to very fine roots; 50 percent low chroma sandstone, 2 percent carbolith; slightly acid; clear wavy boundary.

C1-16 to 49 centimeters; (2.5Y 4/1), channery sandy loam; massive; friable; few very fine roots; 50 percent low chroma sandstone, 5 percent carbolith; neutral; abrupt wavy boundary.

C2 -42 to 91 centimeters; brown to dark brown (10YR 4/3), flaggy loam; massive; friable; few very fine roots; 50 percent high chroma sandstone, 10 percent carbolith; neutral; clear wavy boundary.

C3 -91 t0 125+ centimeters; dark yellowish brown (10YR 4/4), common fine yellowish brown (10YR 5/6) mottles, flaggy loam; massive; friable; very few very fine roots; 50 percent high chroma sandstone, 10 percent carbolith; slightly acid.

Rock fragments disordered in all horizons. 
Location-ARCH Coal Spruce Mine, Logan County, WV, N 37 54' 57’, W 81 51' 11”, Stop Number

Minesoil 11-4. (Described the west side of the pit)

Vegetation-Sericea Lespedeza, Orchard Grass, and Broom sedge

Parent Material- Shale, sandstone, siltstone, coal, and mudstone

Elevation-435 meters

Slope-Steep

Aspect-South

Soil type-Minesoil

Described by J. Sencindiver, July 20, 1999.

Oe -0 to 2 centimeters; root material- partially decomposed leave and roots; many very fine to medium roots; 30 percent sandstone channers high chroma; abrupt wavy boundary.

A-2 to 10 centimeters; brown to dark brown (10YR 4/3), sandy loam, moderate fine and medium granular structure; very friable; many very fine to medium roots; 50 percent sandstone high chroma channers; strongly acid; clear wavy boundary.

C1-10 to 24 centimeters; yellowish brown (10YR 5/4), sandy loam; massive with weak medium subangular blocky structure and weak medium granular structure around roots; friable; common very fine to medium roots; 60 percent high chroma sandstone channers, 1 percent carbolith; strongly acid; clear wavy boundary.

C2 - 24 to 59 centimeters; yellowish brown (10YR 5/4) and yellowish brown (10YR 5/8), loam; massive with weak medium subangular blocky structure around roots; friable; few very fine to medium roots; 55 percent high chroma sandstone channers, 5 percent carbolith; very strongly acid; clear wavy boundary.

C3 -59 to 114 centimeters; dark yellowish brown (10YR 4/6) and yellowish brown (10YR 5/6), loam; massive; firm in place, friable in hand; very few very fine to medium roots; 55 percent high chroma and low chroma sandstone channers, 5 percent carbolith; very strongly acid; clear wavy boundary.

C4-114 to 125+ centimeters; dark gray (10YR 4/1), common fine yellowish brown (10YR 5/6) mottles, loam; massive; friable; 60 percent low chroma sandstone, 10 percent carbolith; very strongly acid.

Rock fragments disordered in all horizons. 
Location-ARCH Coal Spruce Mine, Logan County, WV, N 37 54' 52”, W 81 50’ 58”, Stop Number

Minesoil 11-5. (Described north side of the pit)

Vegetation-Sericea Lespedeza, Birdsfoot Treefoil, Broomsedge, and Tall Fescue

Parent Material- Sandstone, and small amounts of shale, siltstone, mudstone and coal

Elevation- 448 meters

Slope-nearly level

Soil type Minesoil

Described by J. Sencindiver, July 20, 1999

A-0 to 9 centimeters; dark brown (10YR 3/3), sandy loam; weak medium subangular blocky structure breaking to weak fine granular structure; very friable; many fine to very fine roots; 30 percent low chroma and high chroma sandstone channers; slightly acid; clear wavy boundary.

C1 -9 to 222 centimeters; dark gray (10YR 4/1), sandy loam; massive; friable; common fine to very fine roots; 55 percent low chroma sandstone channers, 5 percent mudstone, 5 percent carbolith; slightly acid; clear wavy boundary. (Firm in place and friable in hand)

C2-22 to 45 centimeters; dark grayish brown (2.5Y 4/2), common medium yellowish brown (10YR 5/6) mottles, sandy loam; massive; friable; few very fine to fine roots; 70 percent low chroma and high chroma sandstone channers, 5 percent mudstone, 5 percent carbolith; neutral; gradual wavy boundary. (Firm in place and friable in hand)

C3 - 45 to 79 centimeters; $(2.5 \mathrm{Y} 4 / 1)$, sandy loam; massive; friable; few very fine to fine roots; 55 percent low chroma sandstone flags and channers, 2 percent mudstone flags and channers, 5 percent carbolith; neutral; gradual wavy boundary. (Firm in place and friable in hand)

C4-79 to $135+$ centimeters; (2.54Y 4/1), loam; massive; friable; very few very fine roots; 50 percent low chroma sandstone flags and channers, 15 percent mudstone flags and channers, 5 percent carbolith; neutral.

Rock fragments disordered in all horizons. 
Location-ARCH Coal Spruce Mine, Logan County, WV, N 37 54' 53”, W 81 50’ 58”, Stop Number

Minesoil 11-6. (Described the west of the pit)

Vegetation-Broomsedge, Birdsfoot Treefoil, Parnicum, and Tall Fescue

Parent Material- Sandstone, and small amounts of siltstone, shale, mudstone, and coal

Elevation- 452 meters

Slope-Steep

Aspect-South

Soil type-Minesoil

Described by J. Sencindiver, July 20, 1999.

A- 0 to 7 centimeters; dark brown (10YR 4/3) and dark brown (10YR 3/3), loam; moderate fine and medium granular structure; very friable; many very fine to fine roots; 30 percent high chroma sandstone channers; strongly acid; clear wavy boundary.

AC -7 to 36 centimeters, dark brown (10YR 4/3), loam; weak and moderate medium and coarse subangular blocky structure; friable; common very fine to fine roots; 60 percent high chroma sandstone channers, 1 percent carbolith; few bridging voids 1 to 5 centimeters in diameter; strongly acid; gradual wavy boundary. (In some areas, roots matted around rock fragments)

CB - 36 to 72 centimeters; dark brown (10YR 4/3), few medium and coarse strong brown (7.5YR 5/6) mottles, flaggy sandy loam; weak coarse subangular blocky structure; friable; few very fine to fine roots; 75 percent sandstone channers and flags, 1 percent carbolith; few bridging voids 1 to 5 centimeters in diameter; strongly acid; clear wavy boundary.

C-72 to $150+$ centimeters; ( $2.5 \mathrm{Y} \mathrm{5/3),} \mathrm{sandy} \mathrm{loam;} \mathrm{massive;} \mathrm{firm} \mathrm{in} \mathrm{place} \mathrm{friable} \mathrm{in} \mathrm{hand;} \mathrm{very}$ few very fine to fine roots; 50 percent sandstone channers, 5 percent carbolith; strongly acid.

Disordered rock fragments in all horizons. 
Location-ARCH Coal DAL-TEX Mine, Logan County, WV, N 37 55’22”, W 81 50' 17’, Stop Number

Minesoil 7-1. (Described north side of the pit)

Vegetation-Sericea Lespedeza, Birdsfoot Treefoil, Autumn Olive, Orchard Grass, and Tall Fescue

Parent Material- Sandstone, and small amounts of shale, siltstone, mudstone and coal

Elevation-440 meters

Slope-Nearly Level

Soil type-Minesoil

Described by J. Sencindiver, July 21, 1999.

A- 0 to 10 centimeters; dark brown (10YR 3/3), loam; moderate fine to very fine granular structure; very friable; many fine to very fine roots; 25 percent sandstone channers; slightly acid; clear wavy boundary.

C1/B-10 to 30 centimeters; (2.5Y 4/3), sandy loam; 40 percent weak medium and fine subangular blocky structure, 60 percent massive; friable; common very fine to fine roots; 50 percent sandstone channers, 5 percent mudstone, 5 percent carbolith; slightly acid; gradual wavy boundary. (roots matted around rocks and most subangular blocky structure is around the roots)

C2/B - 30 to 107 centimeters; dark grayish brown (10YR 4/2), sandy loam; 25 percent weak fine subangular blocky structure, 75 percent massive; friable; few very fine to fine roots; 60 percent sandstone channers and flags, 5 percent mudstone; 5 percent carbolith; common bridging voids 1 to 5 centimeters in diameter; neutral; clear wavy boundary. (roots matted around rocks and most subangular blocky structure is around the roots)

C-77 to $125+$ centimeters; yellowish brown (10YR 5/4), common fine brownish yellow (10YR 6/8) mottles, sandy loam; massive; very friable; very fine to fine roots; 60 percent sandstone flags and channers, 10 percent mudstone; 5 percent carbolith; neutral.

Rock fragments disordered in all horizons. 
Location-ARCH Coal DAL-TEX Mine, Logan County, WV, N 37 55’ 23”, W 81 50’ 19”, Stop Number

Minesoil 7-2. (Described north up-hill side of the pit)

Vegetation-Sericea Lespedeza, Birdsfoot Treefoil, Bicolor Lespedeza, and Tall Fescue Parent Material- Sandstone, and small amounts of shale, siltstone, mudstone and coal Elevation-443 meters

Slope-Steep

Aspect-South 160

Soil type Minesoil

Described by J. Sencindiver and Pate0, July 21, 1999.

Oi- 0 to 2 centimeters; leaf and stem litter.

A-2 to 8 centimeters; dark gray (10YR 4/1), sandy loam; moderate fine and medium granular structure; very friable; many very fine to fine roots; 25 percent sandstone channers; moderately acid; clear wavy boundary.

AC -8 to 30 centimeters; dark gray (10YR 4/1), sandy loam; moderate medium subangular blocky structure; friable; common very fine to fine roots; 35 percent sandstone, 4 percent mudstone, 1 percent carbolith; moderately acid; clear wavy boundary.

C1/B - 30 to 60 centimeters; mixed dark brown to brown (10YR 4/3) and dark gray (10YR 4/1), sandy loam; 90 percent massive, 10 percent moderate medium subangular blocky structure around the roots; firm in place friable in hand common very fine to fine roots; 45 percent sandstone, 5 percent carbolithic; neutral; gradual wavy boundary.

C2/B - 60 to 107 centimeters; dark grayish brown (10YR 4/2) sandy loam borderline loamy sand; 80 percent massive, 20 percent moderate medium subangular blocky structure around roots; firm in place friable in hand; few very fine to fine roots ; 40 percent sandstone, 5 percent mudstone, 5 percent carbolithic; slightly acid; gradual wavy boundary. (pockets friable in place)

C-107-207+ centimeters; (10YR 4/2), sandy loam; 95 percent massive; moderate medium subangular blocky structure around roots; very friable; few very fine to fine roots; 45 percent sandstone channers and flags, 5 percent mudstone, 5 percent carbolithic; neutral. (roots continue past 207 centimeters). 
Location-Spruce Mine, Logan County, WV, N 37 55’21”, W 81 50’20”, Stop Number

Minesoil 7-3. (Described east side of the pit)

Vegetation-Sericea Lespedeza, Birdsfoot Treefoil, Bicolor Lespedeza, Orchardgrass, and Tall Fescue

Parent Material- Sandstone, and small amounts of shale, siltstone, mudstone and coal Elevation-438 meters

Slope-Nearly Level

Soil type Minesoil

Described by J. Sencindiver and Pate, July 21, 1999.

Oe--0 to 2 centimeters; partially decomposed organic matter; abrupt wavy boundary.

A-2 to 6 centimeters; dark gray (10YR 4/1), loam; medium fine subangular blocky structure breaking to primarily fine and medium granular structure; very friable; many very fine to fine roots; 30 percent sandstone channers; very strongly acid; clear wavy boundary.

AC - 6 to 24 centimeters; very dark gray (10YR 3/1), loam/clay loam; primarily coarse subangular blocky structure with moderate medium subangular block structure around roots; friable; common very fine to fine roots; 25 percent mixed gravel's ( 15 percent mudstone, 10 percent sandstone channers); very strongly acid; abrupt wavy boundary.

C/B-24 to 48 centimeters; ( $2.5 \mathrm{Y}$ 5/3), loam; 60 percent massive, 40 percent moderate medium and fine subangular blocky structure around roots; friable; common very fine to fine roots; 71 percent channers (70 percent sandstone, 1 percent carbolithic); strongly acid; gradual wavy boundary.

C1-48 to 66 centimeters; brown (10YR 5/3), sandy loam; 95 percent massive, 5 percent primarily medium subangular blocky around roots; firm in place friable in hand; few very fine to fine roots; 70 percent sandstone flags and channers, 4 percent mudstone, 1 percent carbolithic; slightly acid; gradual wavy boundary.

C2 -66 to 99 centimeters; brown (10YR 5/3), sandy loam; massive; friable; few very fine to fine and medium roots; 70 percent sandstone flags and channers, 4 percent mudstone, 1 percent carbolithic; slightly acid; gradual wavy boundary.

C3 -97 to 160+ centimeters; brown (10YR 5/3), sandy loam; massive; friable; very fine to fine and medium roots; 85 percent sandstone stones, 5 percent mudstone stones; very coarse voids up to 10 centimeters; neutral. 
Location-Spruce Mine, Logan County, WV, N 37 55’22”, W 81 50’ 22”, Stop Number

Minesoil 7-4

Vegetation-Sericea Lespedeza, Sourwood, British Solider Lichea, and Dewberry

Parent Material- Sandstone, and small amounts of siltstone, shale, mudstone, and coal

Elevation-445 meters

Slope-Steep

Aspect-South 180

Soil type Minesoil

Described by J. Sencindiver, July 21, 1999

A- 0 to 7 centimeters; very dark gray (10YR 3/1); loam; moderate medium subangular blocky structure; very friable; many very fine to medium roots; 15 percent sandstone channers; extremely acid; clear wavy boundary.

Bw -7 to 21 centimeters; dark grayish brown (10YR 4/2) and brown (10YR 5/3), common fine yellowish brown (10YR 5/6), sandy loam; weak medium subangular blocky structure; friable; common very fine to fine roots; 30 percent sandstone channers; extremely acid; clear wavy boundary.

C1-21 to 42 centimeters; (2.5Y 5/3), sandy loam; massive; firm in place friable in hand; few very fine to medium roots; 40 percent sandstone channers, 3 percent mudstone, 2 percent carbolithic; extremely acid; D wavy boundary.

C2-42 to 101 centimeters; (2.5Y 5/3), sandy loam; massive; firm in place friable in hand; 40 percent sandstone channers, 3 percent mudstone, 2 percent carbolithic; extremely acid; gradual wavy boundary.

C3 - 101 to $160+$ centimeters; ( $2.5 \mathrm{Y}$ 5/3), sandy loam; massive; friable; 50 percent sandstone flags and channers, 5 percent mudstone, 1 percent carbolith; extremely acid.

Rock Fragments disordered in all horizons. 
Location-Spruce Mine, Logan County, WV, N 37 55’ 20”, W 81 50’2 25”, Stop Number

Minesoil 7-5. (Described west side of the pit)

Vegetation- Bicolor Lespedeza, Tall Fescue, Sericea Lespedeza, Birdsfoot Treefoil, and Orchardgrass.

Parent Material- Mainly siltstone and sand stone with small amounts of shale mudstone, and coal Elevation-440 meters

Slope-Nearly Level

Soil type Minesoil

Described by J. Sencindiver, July 22, 1999

Oe -0 to 2 centimeters; partially decomposed leaf and stem litter; 35 percent sandstone channers and gravel; abrupt wavy boundary.

A-2 to 7 centimeters; very dark grayish brown (2.5Y 3/2), loam; weak fine and medium granular structure; very friable; many very fine to medium roots; 35 percent sandstone channers and gravel; strongly acid; clear wavy boundary.

AC -7 to 37 centimeters; $(2.5 \mathrm{Y} 4 / 1)$ and (2.5Y 3/1), loam; weak and moderate fine and medium subangular blocky structure; friable; common very fine to medium roots concentrated around rock fragments; 50 percent channers and flags, 60 percent sandstone, 35 percent mudstone, 5 percent carbolithic; moderately acid; clear wavy boundary.

C1/B - 37 to 91 centimeters; (2.5Y 3/1), loam; 60 percent massive, 40 percent weak fine subangular blocky structure breaking to weak fine granular; friable; common very fine to medium roots. concentrated around rock fragments; 60 percent channers, flags, and gravel, 60 percent sandstone, 35 percent mudstone, 5 percent carbolithic; strongly acid; gradual wavy boundary

C2/B - 92 to 140+ centimeters; (2.5Y 3/1), loam; 85 percent massive, 15 percent weak fine subangular blocky structure breaking to weak fine granular structure; few very fine to medium roots; 70 percent channers, flags, and gravel, 60 percent sandstone, 35 percent mudstone, 5 percent carbolithic; strongly acid; (Roots concentrated around bottom of pit) 
Location-Arch Coal, Logan County, WV, N 37 55’21”, W 81 50’25”, Stop Number

Minesoil 7-6 (Described east side of the pit)

Vegetation-Bicolor Lespedeza, Sourwood, Sericea Lespedeza, Broomsedge, and Red Maple (Vegetation is sparse at site)

Parent Material- Sandstone, and small amounts of siltstone, shale, mudstone, and coal Elevation-448 meters

Slope-Steep

Aspect-South

Soil type Minesoil

Described by J. Sencindiver, July 22, 1999

A1 - 0 to 10 centimeters; dark grayish brown (10YR 4/2) and very dark grayish brown (10YR $3 / 2$ ), sandy loam; moderate fine to medium granular structure; very friable; many very fine to medium roots; 30 percent channers 90 percent sandstone, 10 percent carbolithic; extremely acid; clear wavy boundary.

A2 - 10 to 10 centimeters; brown (10YR 5/3); sandy loam; weak medium granular; very friable; many very fine to medium roots; 35 percent sandstone channers; extremely acid; clear wavy boundary.

AC - 19 to 32 centimeters; light yellowish brown (10YR 6/4), sandy loam; weak medium subangular blocky structure breaking to weak medium granular structure; friable; common very fine to medium roots; 40 percent sandstone channers; extremely acid; clear wavy boundary.

C1-32 to 73 centimeters; yellowish brown (10YR 5/4), sandy loam; massive with 10 percent weak medium subangular blocky structure around roots; very friable; few very fine to medium roots; 50 percent sandstone channers; extremely acid; gradual wavy boundary.

C2 -73 to 110+ centimeters; yellowish brown (10YR 5/4), sandy loam; massive; very friable; very few very fine to fine roots; 50 percent sandstone channers; extremely acid. (Standing water present) 
Location-Arch Coal, Logan County, WV, N 37 56’ 11’, W 81 51’16”, Stop Number

Minesoil 2-1 (Described north side of the pit)

Vegetation-Orchardgrass, Tall Fescue, Birdsfoot Trefoil, Red Clover and Ryegrass

Parent Material- Sandstone, and small amounts of siltstone, shale, mudstone, and coal Elevation-530 meters

Slope-3 percent

Soil type Minesoil

Described by J. Sencindiver, August 10, 1999

$\mathbf{O i}-0$ to 1 centimeters; grass stems.

A-1 to 4 centimeters; brown to dark brown (10YR 4/3), sandy loam; weak fine granular structure; very friable; many very fine to fine roots; 40 percent gravel, 90 percent sandstone, 5 percent mudstone, 5 percent carbolithic; very strongly acid; clear wavy boundary.

AC - 4 to 10 centimeters; brown to dark brown (10YR 4/3), sandy loam; weak medium subangular blocky structure; friable; common very fine to fine roots; 40 percent gravel 90 percent sandstone, 5 percent mudstone 5 percent carbolithic; very strongly acid; clear wavy boundary.

C1-10 to 41 centimeters; dark grayish brown (2.5Y 4/2), common fine and medium olive yellow (2.5Y 6/6) and (N 2.5/0) mottles, loam; massive; friable; few very fine to fine roots; 50 percent channers 75 percent sandstone, 15 percent carbolithic, 10 percent mudstone; strongly acid; gradual wavy boundary.

C2 - (2.5Y 4/3), common medium (N 2.5/0), yellowish brown (10YR 5/6), strong brown (7.5YR $5 / 8)$, and red (2.5 YR 5/8) mottles, few pockets 20 centimeters in diameter of brownish yellow (10YR 6/6) and olive yellow (2.5Y 6/6), loam; massive; friable; few very fine to fine roots; 60 percent channers 85 percent sandstone, 5 percent mudstone, 15 percent carbolith; strongly acid; abrupt wavy boundary.

C3 -92 to 150+ centimeters; strong brown (7.5YR 5/8), few pockets 10 centimeters in diameter of (2.5Y 7/1), easily crushable mudstone, sandy loam; massive; firm in place friable in hand; 90 percent channers (50 percent easily crushable by hand); strongly acid. (This horizon seems to be primarily soft weathered sandstone) 
Location-Arch Coal, Logan County, WV, N 37 56’ 10”, W 81 51’ 16”, Stop Number

Minesoil 2-2 (Described north side of the pit)

Vegetation-Alfalfa, Orchardgrass, Tall Fescue, and Birdsfoot Trefoil

Parent Material- Mainly siltstone and sand stone with small amounts of shale mudstone, and coal Elevation-530 meters

Slope-steep

Aspect-South

Soil type Minesoil

Described by J. Sencindiver, August 10, 1999

Oi-grass and legume stems.

A-2 to 6 centimeters; very dark grayish brown (2.5Y 3/2), loam; weak fine and medium granular structure; very friable common very fine to medium roots; 30 percent gravel, 80 percent sandstone, 10 percent carbolith, 10 percent mudstone; moderately acid; clear wavy boundary.

C1 -6 to 51 centimeters; very dark grayish brown (2.5Y 3/2), common fine and medium yellowish brown (10YR 5/6), dark yellowish brown (10YR 4/4), and (N 2.5/0) mottles, loam; 10 percent massive weak fine subangular blocky structure in upper part around roots; friable; few very fine to medium roots; 50 percent channers and gravel, 70 percent sandstone, 10 percent carbolithic, 20 percent mudstone; neutral; gradual irregular boundary. (Roots concentrated and matted at this boundary)

C2 - 51 to 104 centimeters; grayish brown (10YR 5/2), common fine and medium yellowish brown (10YR 5/6), and (N 2.5/0) mottles, loam; massive; firm; few very fine to medium roots concentrated and matted around rock fragments; 75 percent gravel and flags, 80 percent sandstone, 10 percent carbolithic, 10 percent mudstone; very strongly acid; clear irregular boundary.

C3--104 to 140+ centimeters; very gray grayish brown (10YR 3/2) to dark garish brown (10YR $4 / 2$ ), few medium (N2.5/0) mottles, sandy loam; massive; friable; very few very fine to medium roots; 40 percent gravel and channers, 70 percent sandstone, 10 percent carbolithic, 20 percent mudstone; strongly acid.

Third horizon is denser than the other horizons above or below it. Material loosely packed in last horizon. 
Location-Arch Coal, Logan County, WV, N 37 56’ 11’, W 81 51' 14”, Stop Number

Minesoil 2-3 (Described west side of the pit)

Vegetation-Orchardgrass, Tall Fescue, Birdsfoot Trefoil, Red Clover and Ryegrass

Parent Material- Shale, sandstone, siltstone, coal, and mudstone

Elevation-520 meters

Slope-3 percent

Soil type Minesoil

Described by J. Sencindiver, August 10, 1999

$\mathbf{O i}-$ Grass and legume stem litter.

A--1 to 7 centimeters; very dark grayish brown (2.5Y 3/2), loam; weak medium subangular blocky structure breaking to moderate medium granular structure; friable; many very fine to medium roots; 20 percent gravel, 50 percent sandstone, 25 percent mudstone, 25 percent carbolith; moderately acid; clear wavy boundary.

AC--7 to 13 centimeters; very dark grayish brown (2.5Y 3/2), loam; weak medium subangular blocky structure; friable; common very fine to medium roots; 20 percent gravel, 50 percent sandstone, 25 percent mudstone, 25 percent carbolith; slightly acid; gradual wavy boundary.

C1--13 to 56 centimeters; (2.5Y 3/1), few medium and coarse yellowish brown (10YR 5/6) mottles, loam; massive; firm; few Very Fine to medium roots; 35 percent channers, 40 percent mudstone, 30 percent sandstone, 30 percent carbolith; strongly acid; abrupt wavy boundary.

C2-56 to 82 centimeters; brownish yellow (10YR 6/6), many fine and medium olive yellow (2.5Y 6/6), (N2.5/0), strong brown (7.5YR 5/6), and light brownish yellow (10YR 6/2) mottles, loam; massive; friable; 30 percent channers, 40 percent sandstone, 30 percent mudstone, 30 percent carbolith; very strongly acid; abrupt wavy boundary.

$\mathbf{2 C r}-82$ to 92 centimeters; Soft gray mudstone. 
Location-Arch Coal, Logan County, WV, N 37 56' 10”, W 81 51' 14”, Stop Number

Minesoil 2-4 (Described east side of the pit)

Vegetation-Alfalfa, Orchardgrass, and Birdsfoot Trefoil,

Parent Material- Sandstone, and small amounts of shale, siltstone, mudstone and coal

Elevation-520 meters

Slope-Steep

Aspect-South

Soil type Minesoil

Described by J. Sencindiver, August 10, 1999

$\mathbf{O i}-0$ to 1 centimeters; Grass and legume stems.

A-1 to 7 centimeters; very dark grayish brown (2.5Y 3/2), loam/sandy loam; moderate (weak) fine granular structure; very friable; many very fine to fine roots; 25 percent gravel, 85 percent sandstone, 10 percent mudstone; 5 percent carbolithic; slightly acid; clear wavy boundary.

C1-7 to 37 centimeters; very dark grayish brown (2.5Y 3/2) and dark grayish brown (2.5Y 4/2), common fine light gray to gray (10YR 6/1) and brownish yellow (10YR 6/6) mottles, loam; massive pockets of weak medium platy structure, 10 percent weak fine subangular blocky around roots; firm; many very fine to medium roots; 45 percent channers, 65 percent sandstone, 25 percent mudstone; 10 percent carbolithic; moderately acid; gradual wavy boundary. (Compacted horizon, but not as bad as C2)

C2-37 to 120 centimeters; (2.5Y 5/3) and very dark grayish brown (2.5Y 3/2), few medium (N2.5/0) mottles; loam; massive; firm; few very fine to medium roots concentrated along rock faces; 75 percent channers, 80 percent sandstone, 10 percent mudstone; 10 percent carbolithic; slightly acid; clear wavy boundary. (Compacted horizon)

C3-120 to 152+ centimeters; light olive brown (2.5Y 5/4) and yellowish brown (10YR 5/6), common fine dark gray (10YR 4/2) and very dark gray (10YR 3/1) mottles; sandy loam; massive; friable; very few very fine roots; 50 percent channers, 85 percent sandstone, 10 percent mudstone; 5 percent carbolithic; slightly acid. 
Location-Arch Coal, Logan County, WV, N 37 56' 10”, W 81 51' 12”, Stop Number

Minesoil 2-5 (Description taken at top of valley fill, north side of the pit was described)

Vegetation-Alfalfa, Orchardgrass, and Birdsfoot Trefoil, Tall Fescue, and Red Clover Parent Material- Sandstone, and small amounts of shale, siltstone, mudstone and coal Elevation-523 meters

Slope-Nearly Level

Soil type Minesoil

Described by J. Sencindiver, August 10, 1999

$\mathbf{O i}-0$ to 1 centimeter; Grass and legume stem litter.

A-1 to 5 centimeters; very dark grayish brown (10YR 3/2), sandy loam; weak medium subangular blocky structure and weak medium granular structure; friable; many very fine to fine roots; 25 percent channers, 90 percent sandstone, 5 percent mudstone, 5 percent carbolithic; strongly acid; clear wavy boundary.

AC -5 to 22 centimeters; dark grayish brown (2.5Y 3/2), few fine and medium (N2.5/0), and light yellowish brown (2.5Y 6/4) mottles, loam; weak medium subangular blocky structure; firm; common very fine to fine roots; 35 percent channers, 65 percent sandstone, 25 percent mudstone, 10 percent carbolithic; slightly acid; clear wavy boundary.

C-22 to 64 centimeters; $(2.5 \mathrm{Y} 4 / 3)$ and $(2.5 \mathrm{Y} 4 / 1)$, many fine and medium (N2.5/0), strong brown (7.5YR 5/6) and light yellowish brown (2.5Y 6/4) mottles, loam; massive; firm; few very fine to medium roots; 40 percent channers, 70 percent sandstone, 25 percent mudstone, 5 percent carbolithic; moderately acid; abrupt wavy boundary

$\mathbf{2 C r}-64$ to $91+$ centimeters; Soft gray mudstone. 
Location-Arch Coal, Logan County, WV, N 37 56’10”, W 81 51' 13”, Stop Number

Minesoil 2-6 (Described west side of the pit)

Vegetation-Alfalfa, Orchardgrass, and Birdsfoot Trefoil,

Parent Material- Sandstone, and small amounts of shale, siltstone, mudstone and coal

Elevation-521 meters

Slope-Steep

Aspect-South

Soil type Minesoil

Described by J. Sencindiver, August 10, 1999

$\mathbf{O i}-0$ to 2 centimeters; Grass and legume stem litter.

A-2 to 8 centimeters; dark brown (10YR 3/3), sandy loam/loam; weak fine granular structure; friable; many very fine to fine roots; 30 percent gravel, 90 percent sandstone, 5 percent mudstone, 5 percent carbolithic; moderately acid; clear wavy boundary.

AC - 8 to 14 centimeters; dark grayish brown (10YR 4/2) and yellowish brown (10YR 5/6), loam; weak medium and fine subangular block structure; friable; many very fine to fine roots; 30 percent gravel, 90 percent sandstone, 5 percent mudstone, 5 percent carbolithic; moderately acid; abrupt wavy boundary.

C/B-14 to 29 centimeters; (2.5Y 4/3), common coarse yellowish brown (10YR 5/6Z) mottles, loam; 60 percent massive, 40 percent weak fine subangular blocky structure; friable; many very fine to medium roots; 70 percent gravel and channers, 80 percent sandstone, 10 percent mudstone, 10 percent carbolithic; moderately acid; gradual wavy boundary.

C-29 to $120+$ centimeters; gray to light gray (10YR 6/1), and (2.5Y 5/3), few medium (N2.5/0) mottles, loam; massive; firm; few very fine to medium, roots; 70 percent boulders and channers, 90 percent sandstone, 5 percent mudstone, 5 percent carbolithic; moderately acid. (Several pieces of wire found) 
Appendix B

Soil Physical Properties 
Table 11. Bulk density and porosity of surface and subsurface horizons for all soil profiles

\begin{tabular}{|c|c|c|c|c|c|c|c|c|}
\hline $\begin{array}{c}\text { Sample } \\
\text { I.D. }\end{array}$ & Horizon & $\begin{array}{c}\text { Average } \\
\text { Depth }\end{array}$ & $\begin{array}{c}\text { Db }>2 \mathrm{~mm} \\
\text { Field State } \\
\mathrm{g} \mathrm{cm}^{-3}\end{array}$ & $\begin{array}{c}\text { Db }<2 \mathrm{~mm} \\
\text { Field State } \\
\mathrm{g} \mathrm{cm}^{-3}\end{array}$ & $\begin{array}{c}\text { Db }>2 \mathrm{~mm} \\
\text { Oven Dry } \\
\mathrm{g} \mathrm{cm}^{-3}\end{array}$ & $\begin{array}{c}\text { Db }<2 \mathrm{~mm} \\
\text { Oven Dry } \\
\mathrm{g} \mathrm{cm}^{-3}\end{array}$ & $\begin{array}{c}\text { \% } \\
\text { POROSITY } \\
\text { Field state }\end{array}$ & $\begin{array}{c}\text { POROSITY } \\
\text { Oven Dry }\end{array}$ \\
\hline $23-01$ & $\mathrm{~A}$ & $3-7$ & $*$ & $*$ & 0.98 & 0.72 & $*$ & 72.3 \\
\hline & $\mathrm{AC}$ & $7-22$ & 1.8 & 1.56 & 1.83 & 1.59 & 30.9 & 40.0 \\
\hline & $\mathrm{C}$ & $22-65$ & 1.77 & 1.56 & 1.80 & 1.60 & 32.1 & 39.8 \\
\hline & & & & & & & & \\
\hline $23-02$ & $\mathrm{~A}$ & $6-13$ & $*$ & $*$ & 1.42 & 1.09 & $*$ & 58.1 \\
\hline & $\mathrm{Bw}$ & $13-31$ & 1.76 & 1.57 & 1.78 & 1.59 & 40.8 & 40.0 \\
\hline & $\mathrm{C} / \mathrm{B}$ & $37-75$ & $*$ & $*$ & $*$ & $*$ & $*$ & $*$ \\
\hline & $\mathrm{C}$ & $75-105+$ & $*$ & $*$ & $*$ & $*$ & $*$ & $*$ \\
\hline & & & & & & & & \\
\hline $23-03$ & $\mathrm{~A}$ & $5-12$ & $*$ & $*$ & 1.17 & 1.10 & $*$ & 57.7 \\
\hline & $\mathrm{AC}$ & $12-30$ & 1.82 & 1.63 & 1.84 & 1.65 & 38.4 & 37.7 \\
\hline & $\mathrm{C} 1$ & $30-87$ & 1.97 & 1.61 & 1.97 & 1.66 & 39.1 & 37.2 \\
\hline & $\mathrm{C} 2$ & $87-115+$ & 1.92 & 1.76 & 1.97 & 1.80 & 33.7 & 32.1 \\
\hline & & & & & & & & \\
\hline $23-04$ & $\mathrm{~A}$ & $4-12$ & $*$ & $*$ & 1.07 & 0.73 & $*$ & 71.9 \\
\hline & $\mathrm{AC}$ & $12-38$ & 1.93 & 1.65 & 1.93 & 1.61 & 37.7 & 39.3 \\
\hline & $\mathrm{C}$ & $38-69$ & 2.04 & 1.53 & 2.03 & 1.52 & 42.2 & 42.6 \\
\hline & $\mathrm{C} / \mathrm{B}$ & $69-150+$ & 1.86 & 1.53 & 1.85 & 1.51 & 42.4 & 42.8 \\
\hline & & & & & & & & \\
\hline $23-05$ & $\mathrm{~A}$ & $3-8$ & $*$ & $*$ & 1.16 & 0.75 & $*$ & 71.2 \\
\hline & $\mathrm{AC}$ & $8-26$ & 1.94 & 1.79 & 1.96 & 1.80 & 32.4 & 32.0 \\
\hline & $\mathrm{C} 1$ & $26-61$ & 2.21 & 1.93 & 2.22 & 1.93 & 27.2 & 27.4 \\
\hline & & & & & & & & \\
\hline & $\mathrm{A}$ & $5-11$ & $*$ & $*$ & 1.34 & 0.83 & $*$ & 68.1 \\
\hline & $\mathrm{C}$ & $26-120+06$ & 2.01 & 1.76 & 2.03 & 1.79 & 33.6 & 32.6 \\
\hline
\end{tabular}




\begin{tabular}{|c|c|c|c|c|c|c|c|c|}
\hline $\begin{array}{l}\text { Sample } \\
\text { I.D. }\end{array}$ & Horizon & $\begin{array}{l}\text { Average } \\
\text { Depth }\end{array}$ & $\begin{array}{c}\mathrm{Db}>2 \mathrm{~mm} \\
\text { Field State } \\
\mathrm{g} \mathrm{cm}^{-3}\end{array}$ & \begin{tabular}{|c|}
$\mathrm{Db}<2 \mathrm{~mm}$ \\
Field State \\
$\mathrm{g} \mathrm{cm}^{-3}$
\end{tabular} & $\begin{array}{c}\mathrm{Db}>2 \mathrm{~mm} \\
\text { Oven Dry } \\
\mathrm{g} \mathrm{cm}^{-3}\end{array}$ & $\begin{array}{c}\mathrm{Db}<2 \mathrm{~mm} \\
\text { Oven Dry } \\
\mathrm{g} \mathrm{cm}^{-3}\end{array}$ & $\begin{array}{c}\% \\
\text { POROSITY } \\
\text { Field state }\end{array}$ & $\begin{array}{c}\% \% \\
\text { POROSITY } \\
\text { Oven Dry }\end{array}$ \\
\hline \multirow[t]{4}{*}{ 11-01 } & $\bar{A}$ & $3-11$ & $*$ & $*$ & 1.70 & 1.26 & $*$ & 51.5 \\
\hline & $\mathrm{AC}$ & $11-37$ & 2.05 & 1.77 & 2.06 & 1.78 & 33.2 & 32.8 \\
\hline & $\mathrm{C} 1$ & $37-89$ & 1.99 & 1.65 & 2.03 & 1.69 & 37.7 & 36.2 \\
\hline & $\mathrm{C} 2$ & $89-160+$ & 1.94 & 1.30 & 1.96 & 1.32 & 50.9 & 50.2 \\
\hline \multirow[t]{4}{*}{$11-02$} & $\bar{A}$ & $3-12$ & * & * & 1.4 & 0.97 & * & 62.7 \\
\hline & $\mathrm{AC}$ & $12-41$ & * & * & * & 0.85 & * & 67.9 \\
\hline & $\mathrm{C} 1$ & $41-75$ & 1.92 & 1.70 & 1.87 & 1.63 & 35.8 & 38.5 \\
\hline & $\mathrm{C} 2$ & $75-125+$ & * & * & * & * & * & * \\
\hline \multirow[t]{5}{*}{$11-03$} & A & $0-3$ & * & $*$ & 1.28 & 0.85 & * & 67.3 \\
\hline & $\mathrm{AC}$ & $3-16$ & 1.93 & 1.60 & 1.97 & 1.50 & $*$ & * \\
\hline & $\mathrm{C} 1$ & $16-49$ & 1.82 & 1.41 & 1.87 & 1.48 & 46.8 & 44.2 \\
\hline & $\mathrm{C} 2$ & $49-91$ & 1.97 & 1.70 & 1.99 & 1.73 & 35.8 & 34.7 \\
\hline & $\mathrm{C} 3$ & $91-125$ & * & * & * & * & * & $*$ \\
\hline \multirow[t]{5}{*}{$11-04$} & $\bar{A}$ & $2-8$ & * & * & 1.50 & 1.02 & * & 60.8 \\
\hline & $\mathrm{C} 1$ & $8-24$ & 1.95 & 1.66 & 1.95 & 1.66 & 37.4 & 37.4 \\
\hline & $\mathrm{C} 2$ & $24-59$ & 2.02 & 1.82 & 2.04 & 1.83 & 31.3 & 30.9 \\
\hline & $\mathrm{C} 3$ & 59-114 & 1.94 & 1.82 & 1.95 & 1.83 & 31.3 & 30.9 \\
\hline & $\mathrm{C} 4$ & $\begin{array}{l}114- \\
125+\end{array}$ & 1.92 & 1.74 & 1.95 & 1.72 & 34.3 & 35.1 \\
\hline \multirow[t]{5}{*}{$11-05$} & $\bar{A}$ & $0-9$ & * & * & 1.80 & 1.43 & * & 45.0 \\
\hline & $\mathrm{C} 1$ & $9-22$ & 2.05 & 1.89 & 2.07 & 1.91 & 28.7 & 27.9 \\
\hline & $\mathrm{C} 2$ & $22-45$ & 2.04 & 1.59 & 2.16 & 1.55 & 40 & 41.5 \\
\hline & $\mathrm{C} 3$ & $45-79$ & * & * & * & * & * & * \\
\hline & $\mathrm{C} 4$ & 79-135+ & * & * & * & * & * & * \\
\hline \multirow[t]{4}{*}{$11-06$} & $\mathrm{~A}$ & $0-7$ & $*$ & $*$ & 1.42 & 1.06 & * & 59.2 \\
\hline & Ac & $7-36$ & 2.34 & 1.55 & 1.77 & 1.57 & 41.5 & 40.8 \\
\hline & $\mathrm{CB}$ & $36-72$ & 2.21 & 1.61 & 1.84 & 1.62 & 39.2 & 38.9 \\
\hline & $\bar{C}$ & $72-150+$ & 2.02 & 1.75 & 2.00 & 1.76 & 34.0 & 33.6 \\
\hline
\end{tabular}




\begin{tabular}{|c|c|c|c|c|c|c|c|c|}
\hline $\begin{array}{l}\text { Sample } \\
\text { I.D. }\end{array}$ & Horizon & $\begin{array}{c}\text { Average } \\
\text { Depth }\end{array}$ & $\begin{array}{c}\mathrm{Db}>2 \mathrm{~mm} \\
\text { Field State } \\
\mathrm{g} \mathrm{cm}^{-3}\end{array}$ & $\begin{array}{c}\mathrm{Db}<2 \mathrm{~mm} \\
\text { Field State } \\
\mathrm{g} \mathrm{cm}^{-3}\end{array}$ & $\begin{array}{c}\mathrm{Db}>2 \mathrm{~mm} \\
\text { Oven Dry } \\
\mathrm{g} \mathrm{cm}^{-3}\end{array}$ & \begin{tabular}{|c|}
$\mathrm{Db}<2 \mathrm{~mm}$ \\
Oven Dry \\
$\mathrm{g} \mathrm{cm}^{-3}$
\end{tabular} & \begin{tabular}{|c|}
$\%$ \\
POROSITY \\
Field state \\
\end{tabular} & $\begin{array}{c}\% \\
\text { POROSITY } \\
\text { Oven Dry }\end{array}$ \\
\hline \multirow[t]{4}{*}{$7-01$} & A & $0-8$ & $*$ & $*$ & 1.69 & 1.20 & $*$ & 53.8 \\
\hline & $\mathrm{C} 1 / \mathrm{B}$ & $8-30$ & 2.09 & 1.56 & 2.10 & 1.58 & 41.1 & 40.4 \\
\hline & $\mathrm{C} 2 / \mathrm{B}$ & $30-77$ & $*$ & $*$ & $*$ & $*$ & $*$ & * \\
\hline & $\mathrm{C}$ & $77-125+$ & $*$ & $*$ & $*$ & $*$ & $*$ & $*$ \\
\hline \multirow[t]{5}{*}{$7-02$} & $\mathrm{~A}$ & $2-8$ & $*$ & $*$ & 1.57 & 0.95 & $*$ & 63.5 \\
\hline & $\mathrm{AC}$ & $8-24$ & 1.93 & 1.51 & 1.98 & 1.57 & 43.02 & 40.8 \\
\hline & $\mathrm{C} 1 / \mathrm{B}$ & $24-60$ & 2.04 & 1.63 & 2.07 & 1.65 & 38.49 & 37.7 \\
\hline & $\mathrm{C} 2 / \mathrm{B}$ & $60-107$ & 1.88 & 1.51 & 1.89 & 1.52 & 43.02 & 42.6 \\
\hline & $\mathrm{C}$ & $\begin{array}{l}107- \\
207+\end{array}$ & 2.09 & 1.43 & 2.10 & 1.44 & 46.04 & 45.7 \\
\hline \multirow[t]{6}{*}{$7-03$} & A & $2-6$ & $*$ & $*$ & 1.34 & 0.88 & $*$ & 66.2 \\
\hline & $\mathrm{AC}$ & $6-28$ & 1.93 & 1.66 & 1.94 & 1.68 & 37.36 & 36.6 \\
\hline & $\mathrm{C} / \mathrm{B}$ & $24-48$ & $*$ & $*$ & $*$ & $*$ & $*$ & $*$ \\
\hline & $\mathrm{C} 1$ & $48-66$ & $*$ & $*$ & $*$ & $*$ & $*$ & $*$ \\
\hline & $\mathrm{C} 2$ & $66-97$ & $*$ & $*$ & $*$ & $*$ & $*$ & $*$ \\
\hline & C3 & $97-160+$ & $*$ & $*$ & $*$ & $*$ & * & $*$ \\
\hline \multirow[t]{5}{*}{$7-04$} & A & $0-7$ & $*$ & $*$ & 1.34 & 0.88 & $*$ & 66.2 \\
\hline & $\mathrm{Bw}$ & $7-21$ & 1.81 & 1.56 & 1.84 & 1.59 & 41.1 & 40.0 \\
\hline & $\mathrm{C} 1$ & $21-42$ & 2.05 & 1.67 & 2.06 & 1.61 & 37.0 & 39.2 \\
\hline & $\mathrm{C} 2$ & $42-101$ & 1.94 & 1.61 & 1.93 & 1.65 & 39.2 & 37.7 \\
\hline & C3 & $\begin{array}{l}101- \\
160+ \\
\end{array}$ & $*$ & $*$ & $*$ & $*$ & $*$ & $*$ \\
\hline \multirow[t]{4}{*}{$7-05$} & $\mathrm{~A}$ & $2-7$ & $*$ & $*$ & 1.37 & 0.86 & $*$ & 66.9 \\
\hline & $\mathrm{AC}$ & $7-37$ & 2.04 & 1.52 & 2.06 & 1.54 & 42.6 & 41.9 \\
\hline & $\mathrm{C} 1 / \mathrm{B}$ & $37-92$ & 1.98 & 1.41 & 2.00 & 1.34 & 46.8 & 49.4 \\
\hline & $\mathrm{C} 2 / \mathrm{B}$ & 92-140+ & 1.88 & 1.30 & 1.89 & 1.36 & 50.9 & 48.7 \\
\hline \multirow[t]{5}{*}{$7-06$} & A1 & $0-10$ & $*$ & $*$ & 1.27 & 0.98 & $*$ & 62.3 \\
\hline & $\mathrm{A} 2$ & $10-19$ & * & 1.15 & 1.45 & 1.21 & 56.6 & 54.3 \\
\hline & $\mathrm{AC}$ & $19-32$ & 1.36 & 1.53 & 2.09 & 1.56 & 42.3 & 41.1 \\
\hline & $\mathrm{C} 1$ & $32-73$ & 2.06 & 1.50 & 2.13 & 1.60 & 43.4 & 39.6 \\
\hline & $\mathrm{C} 2$ & 73-110+ & 2.07 & 1.73 & $*$ & 1.79 & 34.7 & 32.5 \\
\hline
\end{tabular}




\begin{tabular}{|c|c|c|c|c|c|c|c|c|}
\hline \begin{tabular}{|l} 
Sample \\
I.D.
\end{tabular} & Horizon & $\begin{array}{l}\text { Average } \\
\text { Depth }\end{array}$ & \begin{tabular}{|c|}
$\mathrm{Db}>2 \mathrm{~mm}$ \\
Field State \\
$\mathrm{g} \mathrm{cm}^{-3}$
\end{tabular} & \begin{tabular}{|c|}
$\mathrm{Db}<2 \mathrm{~mm}$ \\
Field State \\
$\mathrm{g} \mathrm{cm}^{-3}$
\end{tabular} & $\begin{array}{c}\mathrm{Db}>2 \mathrm{~mm} \\
\text { Oven Dry } \\
\mathrm{g} \mathrm{cm}^{-3}\end{array}$ & $\begin{array}{c}\mathrm{Db}<2 \mathrm{~mm} \\
\text { Oven Dry } \\
\mathrm{g} \mathrm{cm}^{-3}\end{array}$ & $\begin{array}{c}\% \\
\text { POROSITY } \\
\text { Field state }\end{array}$ & $\begin{array}{c}\% \\
\text { POROSITY } \\
\text { Oven Dry }\end{array}$ \\
\hline \multirow[t]{5}{*}{$2-01$} & A & $1-4$ & * & * & 1.45 & 1.26 & * & 51.5 \\
\hline & $\mathrm{AC}$ & $4-10$ & 1.90 & 1.65 & 1.91 & 1.66 & 37.7 & 37.4 \\
\hline & $\mathrm{C} 1$ & $10-41$ & 1.72 & 1.45 & 1.74 & 1.38 & 45.3 & 47.9 \\
\hline & $\mathrm{C} 2$ & $41-92$ & 1.70 & 1.39 & 1.73 & 1.44 & 47.5 & 45.7 \\
\hline & $\mathrm{C} 3$ & \begin{tabular}{|l|}
$92-150+$ \\
\end{tabular} & 1.89 & 1.67 & 1.93 & 1.70 & 37.0 & 35.8 \\
\hline \multirow[t]{4}{*}{$2-02$} & $\overline{\mathrm{A}}$ & $2-6$ & * & $*$ & 1.55 & 0.88 & $*$ & 66.2 \\
\hline & $\mathrm{C} 1$ & $6-51$ & 1.94 & 1.53 & 1.95 & 1.58 & 42.3 & 40.4 \\
\hline & $\mathrm{C} 2$ & 51-104 & 1.87 & 1.63 & 1.88 & 1.64 & 38.5 & 38.1 \\
\hline & $\mathrm{C} 3$ & $\begin{array}{l}104- \\
140+\end{array}$ & 1.68 & 1.38 & 1.70 & 1.40 & 47.9 & 47.2 \\
\hline \multirow[t]{4}{*}{$2-03$} & $\bar{A}$ & $1-7$ & $*$ & $*$ & 1.54 & 1.25 & $*$ & 51.9 \\
\hline & $\mathrm{AC}$ & $7-13$ & 1.77 & 1.59 & 1.95 & 1.60 & 40.0 & 39.6 \\
\hline & $\mathrm{C} 1$ & $13-56$ & 1.75 & 1.44 & 1.77 & 1.46 & 45.7 & 44.9 \\
\hline & $\mathrm{C} 2$ & $56-82$ & 2.14 & 1.98 & 2.14 & 2.02 & 25.3 & 23.8 \\
\hline \multirow[t]{4}{*}{$2-04$} & $\mathrm{~A}$ & $1-7$ & * & * & * & * & * & * \\
\hline & $\mathrm{C} 1$ & $7-37$ & 1.75 & 1.63 & 1.80 & 1.69 & 38.5 & 36.2 \\
\hline & $\mathrm{C} 2$ & $37-120$ & 1.99 & 1.83 & 2.01 & 1.85 & 30.9 & 30.2 \\
\hline & $\mathrm{C} 3$ & $\begin{array}{l}120- \\
152+\end{array}$ & 2.15 & 1.84 & 2.16 & 1.86 & 30.6 & 29.8 \\
\hline \multirow[t]{3}{*}{$2-05$} & A & $1-5$ & $*$ & $*$ & 1.12 & 0.64 & $*$ & 75.4 \\
\hline & $\overline{\mathrm{AC}}$ & $5-22$ & 1.95 & 1.74 & 1.95 & 1.75 & 34.3 & 34.0 \\
\hline & $\mathrm{C}$ & $22-64$ & 2.00 & 1.85 & 2.06 & 1.93 & 30.2 & 27.2 \\
\hline \multirow[t]{4}{*}{$2-06$} & $\mathrm{~A}$ & $2-8$ & $*$ & $*$ & 1.53 & 0.95 & $*$ & 63.5 \\
\hline & $\mathrm{AC}$ & 8-14 & 1.95 & 1.59 & 1.95 & 1.52 & 40.0 & 42.6 \\
\hline & $\mathrm{C} / \mathrm{B}$ & $14-29$ & 1.71 & 1.49 & 1.75 & 1.49 & 43.8 & 43.8 \\
\hline & $\mathrm{C}$ & $29-120+$ & 1.84 & 1.58 & 1.85 & 1.63 & 40.4 & 38.5 \\
\hline
\end{tabular}




\begin{tabular}{|c|c|c|c|c|c|c|c|c|}
\hline $\begin{array}{c}\text { Sample } \\
\text { I.D. }\end{array}$ & Horizon & $\begin{array}{c}\text { Average } \\
\text { Depth }\end{array}$ & $\begin{array}{c}\mathrm{Db}>2 \mathrm{~mm} \\
\text { Field State } \\
\mathrm{g} \mathrm{cm}^{-3}\end{array}$ & $\begin{array}{c}\text { Db }<2 \mathrm{~mm} \\
\text { Field State } \\
\mathrm{g} \mathrm{cm}^{-3}\end{array}$ & $\begin{array}{c}\text { Db }>2 \mathrm{~mm} \\
\text { Oven Dry } \\
\mathrm{g} \mathrm{cm}^{-3}\end{array}$ & $\begin{array}{c}\text { Db }<2 \mathrm{~mm} \\
\text { Oven Dry } \\
\mathrm{g} \mathrm{cm}^{-3}\end{array}$ & $\begin{array}{c}\% \\
\text { POROSITY } \\
\text { Field state }\end{array}$ & $\begin{array}{c}\% \\
\text { POROSITY } \\
\text { Oven Dry }\end{array}$ \\
\hline Native\#1 & $\mathrm{A}$ & $0-9$ & $*$ & $*$ & 0.83 & 0.75 & $*$ & 70.6 \\
\hline & $\mathrm{BA}$ & $9-18$ & 1.36 & 1.28 & 1.40 & 1.31 & 51.7 & 50.6 \\
\hline & $\mathrm{Bw} 1$ & $18-43$ & 1.56 & 1.53 & 1.60 & 1.50 & 42.3 & 43.4 \\
\hline & $\mathrm{Bw} 2$ & $43-67$ & $*$ & $*$ & $*$ & $*$ & $*$ & $*$ \\
\hline & & & & & & & & \\
\hline Native\#2 & $\mathrm{A} / \mathrm{E}$ & $2-5$ & $*$ & $*$ & .65 & 0.46 & $*$ & 82.0 \\
\hline & $\mathrm{BA}$ & $5-23$ & 1.71 & 1.41 & 1.70 & 1.47 & 46.8 & 44.5 \\
\hline & $\mathrm{Bw}$ & $23-59$ & 1.84 & 1.62 & 1.80 & 1.63 & 38.9 & 38.5 \\
\hline & $\mathrm{BC}$ & $59-88$ & $*$ & $*$ & $*$ & $*$ & $*$ & $*$ \\
\hline & & & & & & & & \\
\hline Native\#3 & $\mathrm{A}$ & $.5-3$ & $*$ & $*$ & 1.06 & 0.92 & $*$ & 63.9 \\
\hline & $\mathrm{BA}$ & $3-6$ & $*$ & $*$ & $*$ & $*$ & $*$ & $*$ \\
\hline & $\mathrm{Bw} 1$ & $6-30$ & 1.78 & 1.60 & 1.80 & 1.63 & 39.6 & 38.6 \\
\hline & $\mathrm{Bw} 2$ & $30-41$ & 1.83 & 1.60 & 1.87 & 1.62 & 39.6 & 39.0 \\
\hline & $\mathrm{BC}$ & $41-53$ & 1.87 & 1.60 & 1.90 & 1.65 & 39.6 & 37.6 \\
\hline & $\mathrm{C}$ & $53-65+$ & 1.92 & 1.60 & 1.95 & 1.65 & 39.6 & 37.9 \\
\hline
\end{tabular}


Table 12. Average water stable aggregation of the top two horizons

\begin{tabular}{|c|c|c|c|c|c|}
\hline Sample I.D. & Horizon & WSI & $\begin{array}{c}>2 \mathrm{~mm} \\
\text { Aggregation } \\
\%\end{array}$ & $\begin{array}{c}0.5-2 \mathrm{~mm} \\
\text { Aggregation } \\
\%\end{array}$ & $\begin{array}{c}\text { Total } \\
\text { Aggregation } \\
\%\end{array}$ \\
\hline \multirow[t]{2}{*}{$23-01$} & $A$ & 96.0 & 68.1 & 0.2 & 68.3 \\
\hline & $A C$ & 83.4 & 62.5 & 5.6 & 68.0 \\
\hline \multirow[t]{2}{*}{ 23-02 } & $A$ & 84.4 & 59.6 & 3.2 & 62.1 \\
\hline & $A C$ & 74.0 & 52.7 & 3.4 & 56.2 \\
\hline \multirow[t]{2}{*}{$23-03$} & $A$ & * & * & * & * \\
\hline & $A C$ & 87.2 & 56.0 & 1.6 & 57.6 \\
\hline \multirow[t]{2}{*}{$23-04$} & $A$ & 90.3 & 50.4 & 0.6 & 59.0 \\
\hline & $A C$ & 64.1 & 46.1 & 6.6 & 52.7 \\
\hline \multirow[t]{2}{*}{ 23-05 } & $A$ & 90.1 & 44.5 & 1.2 & 62.2 \\
\hline & $A C$ & 90.1 & 61.1 & 1.4 & 45.7 \\
\hline \multirow[t]{2}{*}{$23-06$} & $A$ & 80.4 & 53.7 & 2.0 & 66.1 \\
\hline & Bw & 53.7 & 34.6 & 4.8 & 39.3 \\
\hline
\end{tabular}

\begin{tabular}{|c|c|c|c|c|c|}
\hline $11-01$ & A & 77.2 & 48.9 & 1.1 & 50.0 \\
\hline & AC & 43.7 & 21.8 & 3.0 & 24.7 \\
\hline & & & & & \\
\hline $11-02$ & A & 94.3 & 63.9 & 1.0 & 64.9 \\
\hline & AC & 74.3 & 36.4 & 9.9 & 46.3 \\
\hline & & & & & \\
\hline $11-03$ & A & 91.8 & 49.2 & 0.4 & 49.7 \\
\hline & AC & 85.2 & 44.7 & 0.9 & 45.6 \\
\hline & & & & & \\
\hline $11-04$ & A & 90.5 & 41.0 & 0.9 & 41.9 \\
\hline & C1 & 69.4 & 33.8 & 2.8 & 36.7 \\
\hline & & & & & \\
\hline $11-05$ & A & 76.5 & 47.9 & 1.6 & 49.5 \\
\hline & C1 & 53.7 & 27.7 & 5.9 & 33.6 \\
\hline & & & & & \\
\hline $11-06$ & A & 95.2 & 72.0 & 1.4 & 73.4 \\
\hline & AC & 76.5 & 43.9 & 15.3 & 59.2 \\
\hline
\end{tabular}




\begin{tabular}{|c|c|c|c|c|c|}
\hline Sample I.D. & Horizon & WSI & $\begin{array}{c}>2 \mathrm{~mm} \\
\text { Aggregation } \\
\%\end{array}$ & $\begin{array}{c}0.5-2 \mathrm{~mm} \\
\text { Aggregation } \\
\%\end{array}$ & $\begin{array}{c}\text { Total } \\
\text { Aggregation } \\
\%\end{array}$ \\
\hline \multirow[t]{2}{*}{$7-01$} & $A$ & 76.5 & 23.6 & 1.3 & 24.8 \\
\hline & C1/B & 78.6 & 28.2 & 0.9 & 29.1 \\
\hline \multirow[t]{2}{*}{$7-02$} & $A$ & 76.4 & 43.9 & 3.0 & 46.8 \\
\hline & $A C$ & 29.1 & 12.9 & 7.8 & 20.7 \\
\hline \multirow[t]{2}{*}{$7-03$} & $A$ & 84.6 & 42.5 & 2.5 & 44.9 \\
\hline & $A C$ & 50.0 & 22.6 & 4.7 & 27.3 \\
\hline \multirow[t]{2}{*}{$7-04$} & $A$ & 69.5 & 44.3 & 3.5 & 47.8 \\
\hline & Bw & 73.9 & 26.0 & 0.9 & 26.9 \\
\hline \multirow[t]{2}{*}{$7-05$} & $A$ & 76.9 & 35.1 & 1.2 & 36.2 \\
\hline & $A C$ & 32.4 & 11.7 & 1.4 & 13.2 \\
\hline \multirow[t]{2}{*}{$7-06$} & $A$ & 67.2 & 14.0 & 0.2 & 14.2 \\
\hline & $A C$ & 38.2 & 14.7 & 3.5 & 18.2 \\
\hline
\end{tabular}

\begin{tabular}{|c|c|c|c|c|c|}
\hline Sample I.D. & Horizon & WSI & $\begin{array}{c}>2 \mathrm{~mm} \\
\text { Aggregation } \\
\%\end{array}$ & $\begin{array}{c}0.5-2 \mathrm{~mm} \\
\text { Aggregation } \\
\%\end{array}$ & $\begin{array}{c}\text { Total } \\
\text { Aggregation } \\
\% \\
\end{array}$ \\
\hline \multirow[t]{2}{*}{$2-01$} & $A$ & 47.2 & 25.8 & 4.7 & 30.4 \\
\hline & $A C$ & 43.3 & 21.9 & 5.6 & 27.6 \\
\hline \multirow[t]{2}{*}{$2-02$} & $A$ & 43.9 & 20.6 & 3.0 & 23.6 \\
\hline & C1 & 12.5 & 2.8 & 4.8 & 7.6 \\
\hline \multirow[t]{2}{*}{$2-03$} & $\bar{A}$ & 34.8 & 18.6 & 4.2 & 22.8 \\
\hline & $A C$ & 12.3 & 5.0 & 3.4 & 8.4 \\
\hline \multirow[t]{2}{*}{ 2-04 } & $A$ & 59.1 & 24.9 & 1.3 & 26.2 \\
\hline & C1 & 32.5 & 9.1 & 10.8 & 19.9 \\
\hline \multirow[t]{2}{*}{$2-05$} & $A$ & 73.9 & 48.2 & 1.1 & 49.3 \\
\hline & $A C$ & 15.9 & 7.1 & 3.4 & 10.5 \\
\hline \multirow[t]{2}{*}{$2-06$} & $A$ & 47.5 & 25.5 & 1.4 & 27.0 \\
\hline & $A C$ & 8.1 & 2.4 & 2.4 & 4.9 \\
\hline
\end{tabular}




\begin{tabular}{|c|c|c|c|c|c|}
\hline Native\#1 & A & 95.9 & 86.8 & 0.3 & 87.1 \\
\hline & BA & 88.2 & 66.0 & 11.0 & 77.0 \\
\hline & & & & & \\
\hline Native\#2 & A/E & 92.9 & 48.7 & 0.5 & 49.3 \\
\hline & BA & 96.9 & 49.8 & 0.2 & 50.0 \\
\hline & & & & & 54.8 \\
\hline Native\#3 & A & 88.8 & 54.4 & 0.4 & 57.8 \\
\hline & BA & 83.1 & 51.1 & 6.6 & \\
\hline & & & & & \\
\hline
\end{tabular}


Table 13. Moisture Retention at $1 / 3$ and 15 bar, and percent water retention difference for Minesoils and Native Soil.

\begin{tabular}{|c|c|c|c|c|c|}
\hline $\begin{array}{c}\text { Sample } \\
\text { I.D. }\end{array}$ & Horizon & texture & $\begin{array}{c}1 / 3 \text { Moisture } \\
\text { Retention } \\
\%\end{array}$ & $\begin{array}{c}15 \text { Bar Moisture } \\
\text { Retention } \\
\%\end{array}$ & $\begin{array}{c}\text { WRD } \\
\%\end{array}$ \\
\hline \multirow[t]{3}{*}{$23-01$} & $A$ & SIL & 20.6 & 9.3 & 10.09 \\
\hline & $A C$ & $\mathrm{~L}$ & 20.1 & 9.3 & 14.32 \\
\hline & C & SICL & 23.1 & 9.6 & 18.57 \\
\hline \multirow[t]{4}{*}{$23-02$} & $A$ & $\mathrm{~L}$ & 16.8 & 6.3 & 6.14 \\
\hline & $A C$ & $\mathrm{~L}$ & 17.2 & 6.8 & 13.09 \\
\hline & $\mathrm{C} / \mathrm{B}$ & SL & 15.7 & 3.7 & 14.25 \\
\hline & $C$ & SL & 15.7 & 3.1 & 15.77 \\
\hline \multirow{4}{*}{$23-03$} & A & L & * & * & * \\
\hline & $A C$ & $\mathrm{~L}$ & 17.3 & 5.7 & 14.66 \\
\hline & C1 & $\mathrm{L}$ & 17.1 & 6.0 & 12.86 \\
\hline & C2 & $\mathrm{L}$ & 18.4 & 6.0 & 16.47 \\
\hline \multirow[t]{4}{*}{$23-04$} & $A$ & $\mathrm{~L}$ & 15.1 & 4.8 & 5.76 \\
\hline & $A C$ & SL & 16.1 & 4.6 & 14.88 \\
\hline & C & SL & 15.3 & 2.6 & 15.37 \\
\hline & C/B & $\mathrm{L}$ & 17.9 & 5.0 & 14.88 \\
\hline \multirow[t]{3}{*}{$23-05$} & A & SL & 13.2 & 2.9 & 7.20 \\
\hline & AC & SL & 15.6 & 5.3 & 14.44 \\
\hline & C1 & SL & 16.9 & 4.4 & 16.82 \\
\hline \multirow[t]{3}{*}{$23-06$} & $A$ & $\mathrm{~L}$ & 16.1 & 5.3 & 6.95 \\
\hline & Bw & $\mathrm{L}$ & 16.4 & 5.7 & 12.76 \\
\hline & C & L & 18.6 & 6.0 & 16.61 \\
\hline
\end{tabular}




\begin{tabular}{|c|c|c|c|c|c|}
\hline $\begin{array}{c}\text { Sample } \\
\text { I.D. }\end{array}$ & Horizon & texture & \begin{tabular}{|c}
$1 / 3$ Bar Moisture \\
Retention \\
$\%$ \\
\end{tabular} & $\begin{array}{c}15 \text { Bar Moisture } \\
\text { Retention } \\
\% \\
\end{array}$ & $\begin{array}{c}\text { WRD } \\
\%\end{array}$ \\
\hline \multirow[t]{4}{*}{$11-01$} & A & SL & 14.4 & 4.5 & 11.04 \\
\hline & $A C$ & $\mathrm{~L}$ & 17.4 & 5.4 & 17.27 \\
\hline & $\mathrm{C} 1$ & $S L$ & 16.8 & 3.3 & 15.78 \\
\hline & $\mathrm{C} 2$ & $\mathrm{~L}$ & 16.4 & 4.4 & 11.97 \\
\hline \multirow[t]{4}{*}{$11-02$} & $A$ & $\mathrm{~L}$ & 15.7 & 5.0 & 8.91 \\
\hline & $\mathrm{AC}$ & $\mathrm{L}$ & 16.0 & 4.5 & 15.97 \\
\hline & C1 & SL & 16.0 & 4.0 & 14.85 \\
\hline & $\mathrm{C} 2$ & $\overline{S L}$ & 17.9 & 3.6 & 17.52 \\
\hline \multirow[t]{5}{*}{ 11-03 } & A & SL & 14.9 & 4.2 & 7.63 \\
\hline & $A C$ & SL & 14.8 & 4.2 & 11.36 \\
\hline & C1 & SL & 13.7 & 3.9 & 11.12 \\
\hline & $\mathrm{C} 2$ & $\mathrm{~L}$ & 16.4 & 5.5 & 13.67 \\
\hline & C3 & $L$ & 18.0 & 6.8 & 13.70 \\
\hline \multirow[t]{5}{*}{ 11-04 } & $A$ & $\mathrm{SL}$ & 16.1 & 2.9 & 10.33 \\
\hline & C1 & SL & 15.9 & 2.5 & 17.31 \\
\hline & $\mathrm{C} 2$ & $\mathrm{~L}$ & 18.0 & 6.3 & 17.75 \\
\hline & C3 & $L$ & 16.2 & 6.5 & 14.05 \\
\hline & C4 & $\mathrm{L}$ & 16.6 & 6.6 & 13.65 \\
\hline \multirow[t]{5}{*}{$11-05$} & A & SL & 14.2 & 4.0 & 11.12 \\
\hline & C1 & SL & 14.7 & 4.5 & 14.77 \\
\hline & $\mathrm{C} 2$ & SL & 15.0 & 4.0 & 12.71 \\
\hline & C3 & SL & 14.1 & 3.9 & 12.71 \\
\hline & C4 & $\mathrm{L}$ & 14.3 & 4.2 & 12.20 \\
\hline \multirow[t]{4}{*}{$11-06$} & $A$ & $\mathrm{~L}$ & 17.0 & 6.4 & 8.67 \\
\hline & $A C$ & $L$ & 17.7 & 6.3 & 14.07 \\
\hline & CB & SL & 15.2 & 5.6 & 11.46 \\
\hline & C & SL & 16.4 & 5.4 & 16.16 \\
\hline
\end{tabular}




\begin{tabular}{|c|c|c|c|c|c|}
\hline $\begin{array}{c}\text { Sample } \\
\text { I.D. }\end{array}$ & Horizon & texture & $\begin{array}{c}1 / 3 \text { Bar Moisture } \\
\text { Retention } \\
\%\end{array}$ & $\begin{array}{c}15 \text { Bar Moisture } \\
\text { Retention } \\
\%\end{array}$ & $\begin{array}{c}\text { WRD } \\
\%\end{array}$ \\
\hline \multirow{4}{*}{$7-01$} & $A$ & $\mathrm{~L}$ & 15.1 & 4.2 & 10.08 \\
\hline & C1/B & SL & 14.4 & 3.9 & 11.72 \\
\hline & C2/B & SL & 14.7 & 3.2 & 14.26 \\
\hline & $C$ & SL & 17.5 & 3.0 & 17.47 \\
\hline \multirow[t]{5}{*}{$7-02$} & $A$ & SL & 17.0 & 5.4 & 8.22 \\
\hline & $A C$ & SL & 14.8 & 5.0 & 11.36 \\
\hline & C1/B & SL & 15.5 & 4.5 & 13.98 \\
\hline & $\mathrm{C} 2 / \mathrm{B}$ & SL & 16.3 & 4.5 & 13.24 \\
\hline & $C$ & SL & 15.3 & 3.9 & 13.65 \\
\hline \multirow[t]{6}{*}{ 7-03 } & $A$ & $\mathrm{~L}$ & 15.9 & 6.4 & 6.70 \\
\hline & $A C$ & $\mathrm{~L} / \mathrm{CL}$ & 16.0 & 6.6 & 12.21 \\
\hline & $\mathrm{C} / \mathrm{B}$ & $L$ & 16.3 & 4.8 & 13.56 \\
\hline & C1 & SL & 12.9 & 3.8 & 10.27 \\
\hline & $\mathrm{C} 2$ & $S L$ & 15.8 & 3.9 & 13.72 \\
\hline & C3 & SL & 15.5 & 3.6 & 13.03 \\
\hline \multirow[t]{5}{*}{$7-04$} & $A$ & $L$ & 15.8 & 6.2 & 6.86 \\
\hline & $\mathrm{Bw}$ & $S L$ & 16.4 & 5.9 & 13.79 \\
\hline & C1 & SL & 15.8 & 3.1 & 15.77 \\
\hline & $\mathrm{C} 2$ & SL & 15.8 & 2.6 & 16.58 \\
\hline & C3 & SL & 15.4 & 4.7 & 12.11 \\
\hline \multirow[t]{4}{*}{ 7-05 } & $A$ & $L$ & 16.9 & 5.5 & 7.24 \\
\hline & $A C$ & $L$ & 17.3 & 5.4 & 13.02 \\
\hline & C1/B & $L$ & 17.8 & 5.0 & 12.55 \\
\hline & $\mathrm{C} 2 / \mathrm{B}$ & $L$ & 17.9 & 5.0 & 12.46 \\
\hline \multirow[t]{5}{*}{$7-06$} & A1 & SL & 15.8 & 3.3 & 9.62 \\
\hline & $\mathrm{A} 2$ & SL & 15.7 & 3.5 & 10.92 \\
\hline & $A C$ & SL & 16.1 & 3.8 & 15.75 \\
\hline & C1 & SL & 17.4 & 3.6 & 16.71 \\
\hline & $\mathrm{C} 2$ & SL & 17.3 & 4.5 & 16.55 \\
\hline
\end{tabular}




\begin{tabular}{|c|c|c|c|c|c|}
\hline $\begin{array}{c}\text { Sample } \\
\text { I.D. }\end{array}$ & Horizon & texture & $\begin{array}{c}\text { 1/3 Bar Moisture } \\
\text { Retention } \\
\%\end{array}$ & $\begin{array}{c}15 \text { Bar Moisture } \\
\text { Retention } \\
\%\end{array}$ & $\begin{array}{c}\text { WRD } \\
\%\end{array}$ \\
\hline \multirow[t]{5}{*}{$2-01$} & $A$ & SL & 15.6 & 4.0 & 9.40 \\
\hline & $A C$ & SL & 16.8 & 5.3 & 16.11 \\
\hline & C1 & $\mathrm{L}$ & 19.3 & 6.8 & 14.26 \\
\hline & $\mathrm{C} 2$ & $L$ & 15.5 & 6.2 & 9.58 \\
\hline & C3 & SL & 12.9 & 3.0 & 13.32 \\
\hline \multirow[t]{4}{*}{$2-02$} & $A$ & $\mathrm{~L}$ & 15.4 & 5.7 & 6.79 \\
\hline & C1 & $L$ & 16.2 & 6.0 & 11.88 \\
\hline & $\mathrm{C} 2$ & $L$ & 16.1 & 7.6 & 10.64 \\
\hline & C3 & SL & 16.6 & 5.2 & 13.09 \\
\hline \multirow[t]{4}{*}{$2-03$} & $\bar{A}$ & $\mathrm{~L}$ & 15.7 & 5.4 & 10.52 \\
\hline & $A C$ & $\mathrm{~L}$ & 17.0 & 6.4 & 13.88 \\
\hline & C1 & $L$ & 17.7 & 7.0 & 11.52 \\
\hline & $\mathrm{C} 2$ & $L$ & 18.0 & 5.9 & 19.60 \\
\hline \multirow[t]{4}{*}{$2-04$} & $A$ & L/SL & 16.3 & 5.7 & 7.31 \\
\hline & C1 & $\mathrm{L}$ & 19.1 & 8.1 & 14.56 \\
\hline & $\mathrm{C} 2$ & $\mathrm{~L}$ & 16.3 & 5.7 & 13.26 \\
\hline & C3 & SL & 16.4 & 4.5 & 16.24 \\
\hline \multirow[t]{3}{*}{$2-05$} & $\mathrm{~A}$ & SL & 17.9 & 5.2 & 7.38 \\
\hline & $A C$ & $L$ & 17.6 & 6.0 & 17.10 \\
\hline & $\mathrm{C}$ & $L$ & 17.6 & 6.0 & 14.56 \\
\hline \multirow[t]{4}{*}{$2-06$} & $A$ & SL/L & 16.8 & 4.2 & 9.89 \\
\hline & $A C$ & $\mathrm{~L}$ & 17.0 & 5.4 & 14.01 \\
\hline & $\mathrm{C}$ & $L$ & 17.3 & 5.5 & 12.69 \\
\hline & $\mathrm{C} / \mathrm{B}$ & $L$ & 17.7 & 5.4 & 14.35 \\
\hline
\end{tabular}




\begin{tabular}{|c|c|c|c|c|c|}
\hline $\begin{array}{c}\text { Sample } \\
\text { I.D. }\end{array}$ & Horizon & texture & $\begin{array}{c}\text { 1/3 Bar Moisture } \\
\text { Retention } \\
\%\end{array}$ & $\begin{array}{c}15 \text { Bar Moisture } \\
\text { Retention } \\
\%\end{array}$ & $\begin{array}{c}\text { WRD } \\
\%\end{array}$ \\
\hline \multirow[t]{4}{*}{ Native\#1 } & $A$ & SIL & 29.3 & 11.3 & 12.82 \\
\hline & BA & SIL & 25.9 & 7.1 & 19.32 \\
\hline & Bw1 & SIL & 23.4 & 7.0 & 21.35 \\
\hline & Bw2 & SIL & 21.7 & 7.7 & 16.51 \\
\hline \multirow[t]{4}{*}{ Native\#2 } & $\mathrm{A} / \mathrm{E}$ & $\overline{S L}$ & 26.9 & 8.1 & 7.35 \\
\hline & $\mathrm{BA}$ & SL & 15.1 & 2.7 & 12.54 \\
\hline & Bw & SL & 15.5 & 3.6 & 13.44 \\
\hline & $B C$ & SL & 15.5 & 3.4 & 15.22 \\
\hline \multirow[t]{6}{*}{ Native\#3 } & $A$ & $\overline{\text { SIL }}$ & 33.1 & 14.1 & 17.15 \\
\hline & $\mathrm{BA}$ & SIL & 26.4 & 8.6 & 20.34 \\
\hline & Bw1 & $\mathrm{L}$ & 20.4 & 6.3 & 16.26 \\
\hline & Bw2 & $\mathrm{L}$ & 19.5 & 6.8 & 13.53 \\
\hline & $B C$ & $\mathrm{~L}$ & 18.2 & 6.3 & 13.71 \\
\hline & $\mathrm{C}$ & $\mathrm{L}$ & 18.0 & 5.9 & 13.21 \\
\hline
\end{tabular}


Table 14. Particle Size Data Including Sand Fractionation for Minesoil and Native Soil.

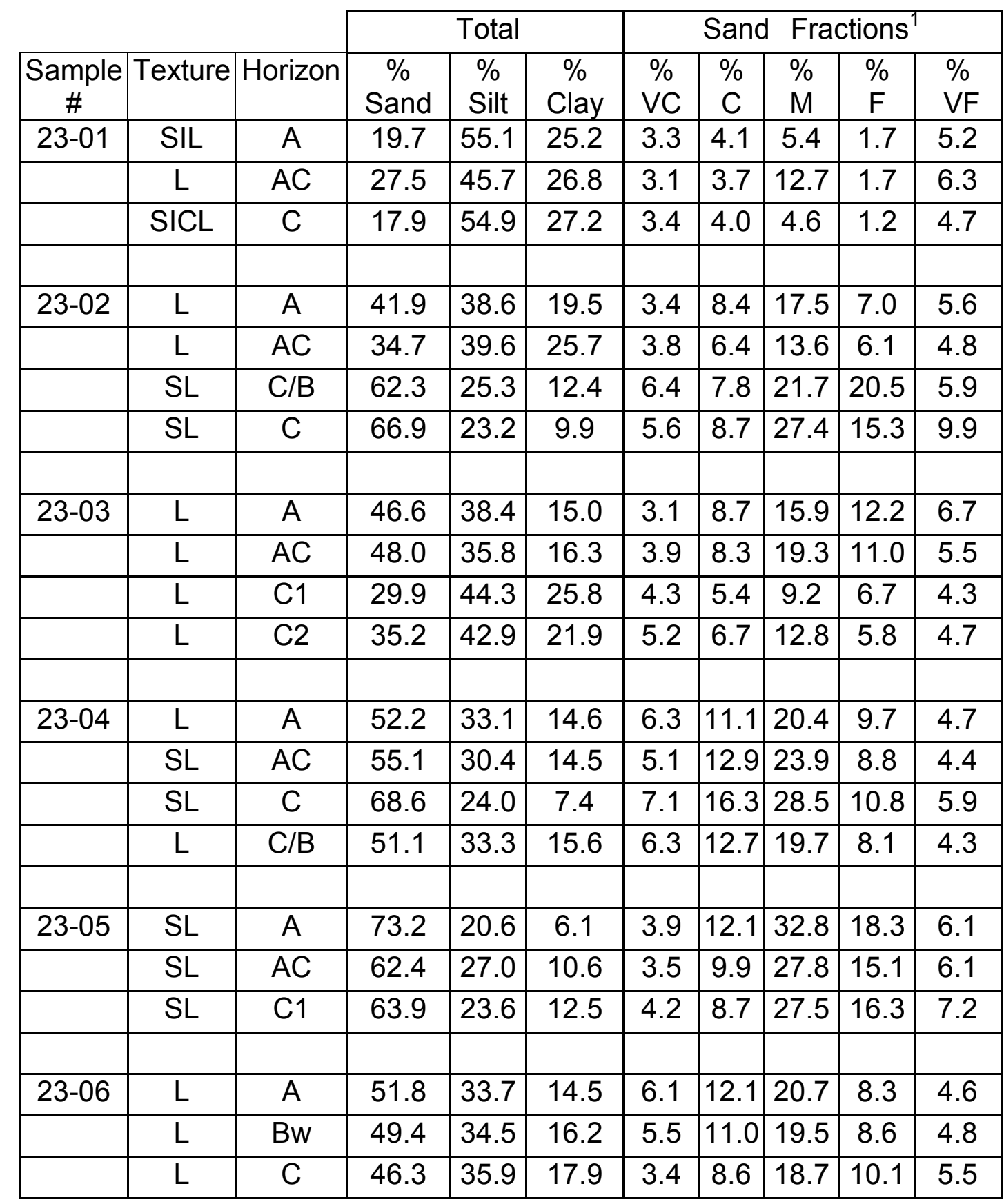




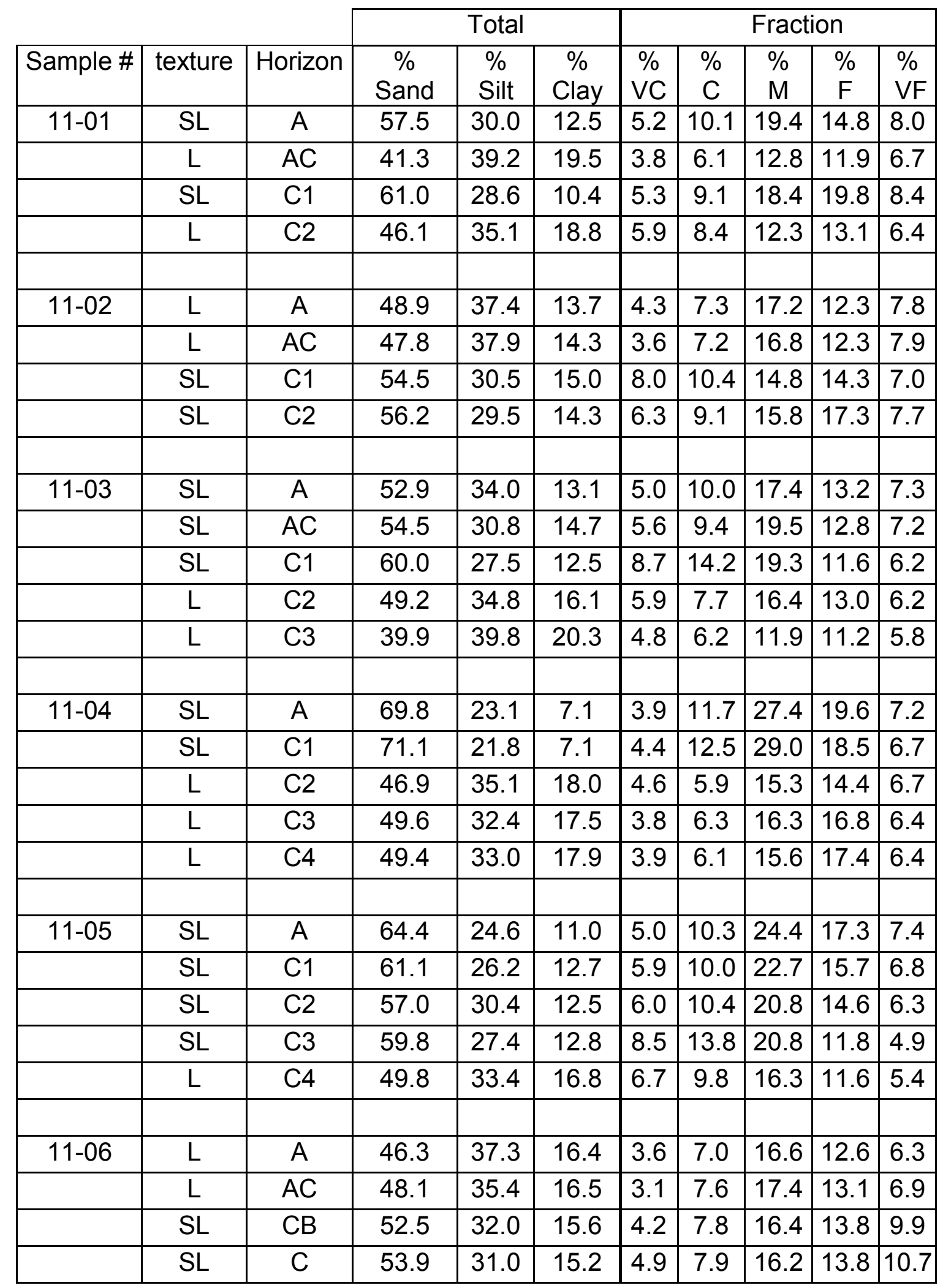




\begin{tabular}{|c|c|c|c|c|c|c|c|c|c|c|}
\hline \multirow{2}{*}{$\begin{array}{c}\text { Sample } \\
\#\end{array}$} & \multirow[b]{2}{*}{ Texture } & \multirow[b]{2}{*}{ Horizon } & \multicolumn{3}{|c|}{ Total } & \multicolumn{5}{|c|}{ Fraction } \\
\hline & & & $\begin{array}{c}\% \\
\text { Sand }\end{array}$ & $\begin{array}{l}\% \\
\text { Silt }\end{array}$ & $\begin{array}{c}\% \\
\text { Clay }\end{array}$ & $\begin{array}{l}\% \\
\text { VC }\end{array}$ & $\begin{array}{l}\% \\
\mathrm{C}\end{array}$ & $\begin{array}{l}\% \% \\
M\end{array}$ & $\begin{array}{l}\% \% \\
F\end{array}$ & $\begin{array}{l}\% \\
\text { VF }\end{array}$ \\
\hline \multirow[t]{4}{*}{$7-01$} & $\mathrm{~L}$ & A & 52.1 & 32.9 & 15.0 & 7.0 & 9.1 & 15.2 & 13.2 & 7.6 \\
\hline & $\mathrm{SL}$ & C1/B & 59.8 & 28.0 & 12.2 & 7.5 & 9.2 & 17.8 & 16.8 & 8.5 \\
\hline & $\mathrm{SL}$ & $\mathrm{C} 2 / \mathrm{B}$ & 64.7 & 25.6 & 9.7 & 9.1 & 13.1 & 18.5 & 16.1 & 7.9 \\
\hline & $\mathrm{SL}$ & $\mathrm{C}$ & 69.0 & 22.2 & 8.8 & 8.8 & 14.4 & 20.6 & 17.5 & 7.7 \\
\hline \multirow[t]{5}{*}{$7-02$} & $\mathrm{SL}$ & $\mathrm{A}$ & 53.6 & 30.8 & 15.6 & 5.4 & 6.3 & 19.3 & 15.6 & 7.0 \\
\hline & $\mathrm{SL}$ & $\mathrm{AC}$ & 54.9 & 29.1 & 16.0 & 4.9 & 7.0 & 20.3 & 15.8 & 6.9 \\
\hline & $\overline{\mathrm{SL}}$ & C1/B & 57.7 & 27.4 & 14.9 & 5.8 & 8.0 & 21.0 & 15.9 & 7.0 \\
\hline & SL & C2/B & 56.4 & 28.1 & 15.5 & 6.6 & 7.4 & 20.2 & 15.5 & 6.7 \\
\hline & SL & $C$ & 64.6 & 23.4 & 12.1 & 5.7 & 8.2 & 23.5 & 19.8 & 7.4 \\
\hline & & & & & & & & & & \\
\hline \multirow{6}{*}{$7-03$} & $\mathrm{~L}$ & A & 36.8 & 37.8 & 25.4 & 4.1 & 5.5 & 12.1 & 9.5 & 5.6 \\
\hline & L/CL & $A C$ & 35.0 & 38.2 & 26.8 & 3.3 & 4.8 & 11.5 & 9.7 & 5.7 \\
\hline & $\mathrm{L}$ & $\mathrm{C} / \mathrm{B}$ & 48.5 & 32.0 & 19.5 & 5.3 & 6.3 & 17.3 & 13.5 & 6.1 \\
\hline & $\overline{S L}$ & C1 & 60.1 & 26.7 & 13.3 & 5.6 & 7.2 & 23.0 & 17.7 & 6.6 \\
\hline & SL & $\mathrm{C} 2$ & 60.5 & 27.0 & 12.5 & 5.9 & 7.6 & 22.9 & 17.7 & 6.4 \\
\hline & $\mathrm{SL}$ & C3 & 66.6 & 22.1 & 11.3 & 6.9 & 8.2 & 25.5 & 19.4 & 6.6 \\
\hline \multirow{5}{*}{$7-04$} & L & A & 51.4 & 32.1 & 16.5 & 4.6 & 98 & 197 & 111 & 6.2 \\
\hline & SL & $\mathrm{Bw}$ & 54.5 & 30.2 & 15.3 & 3.5 & \begin{tabular}{|l|}
0.0 \\
10.1
\end{tabular} & 22.3 & 12.2 & 6.4 \\
\hline & $\overline{S L}$ & C1 & 72.0 & 19.9 & 8.1 & 6.3 & 17.6 & 29.8 & 12.8 & 5.5 \\
\hline & SL & $\mathrm{C} 2$ & 74.5 & 19.0 & 6.5 & 6.9 & 18.4 & 29.3 & 13.7 & 6.2 \\
\hline & $\mathrm{SL}$ & $\mathrm{C} 3$ & 54.9 & 30.4 & 14.8 & 4.6 & 10.7 & 19.6 & 12.0 & 8.0 \\
\hline & & & & & & & & & & \\
\hline \multirow[t]{4}{*}{$7-05$} & $\mathrm{~L}$ & A & 36.8 & 41.1 & 22.1 & 4.9 & 5.2 & 10.0 & 9.7 & 7.0 \\
\hline & $\mathrm{L}$ & $A C$ & 31.8 & 42.4 & 25.9 & 4.2 & 5.0 & 8.5 & 8.1 & 6.0 \\
\hline & $\mathrm{L}$ & C1/B & 32.1 & 43.5 & 24.4 & 5.1 & 5.1 & 6.4 & 7.1 & 8.4 \\
\hline & $\mathrm{L}$ & C2/B & 31.5 & 42.7 & 25.8 & 5.2 & 4.9 & 6.8 & 7.0 & 7.6 \\
\hline \multirow[t]{5}{*}{$7-06$} & SL & A1 & 67.1 & 23.8 & 9.1 & 7.9 & 15.5 & 23.5 & 13.8 & 6.4 \\
\hline & $\mathrm{SL}$ & A2 & 68.1 & 22.5 & 9.4 & 4.4 & 9.0 & 20.9 & 24.3 & 9.5 \\
\hline & $\mathrm{SL}$ & $A C$ & 65.0 & 25.3 & 9.7 & 6.0 & 11.8 & 20.6 & 18.7 & 7.9 \\
\hline & $S L$ & C1 & 68.1 & 21.7 & 10.1 & 5.1 & 7.6 & 21.7 & 25.0 & 8.7 \\
\hline & SL & $\mathrm{C} 2$ & 53.4 & 33.3 & 13.3 & 3.0 & 4.1 & 11.2 & 21.0 & 14.1 \\
\hline
\end{tabular}




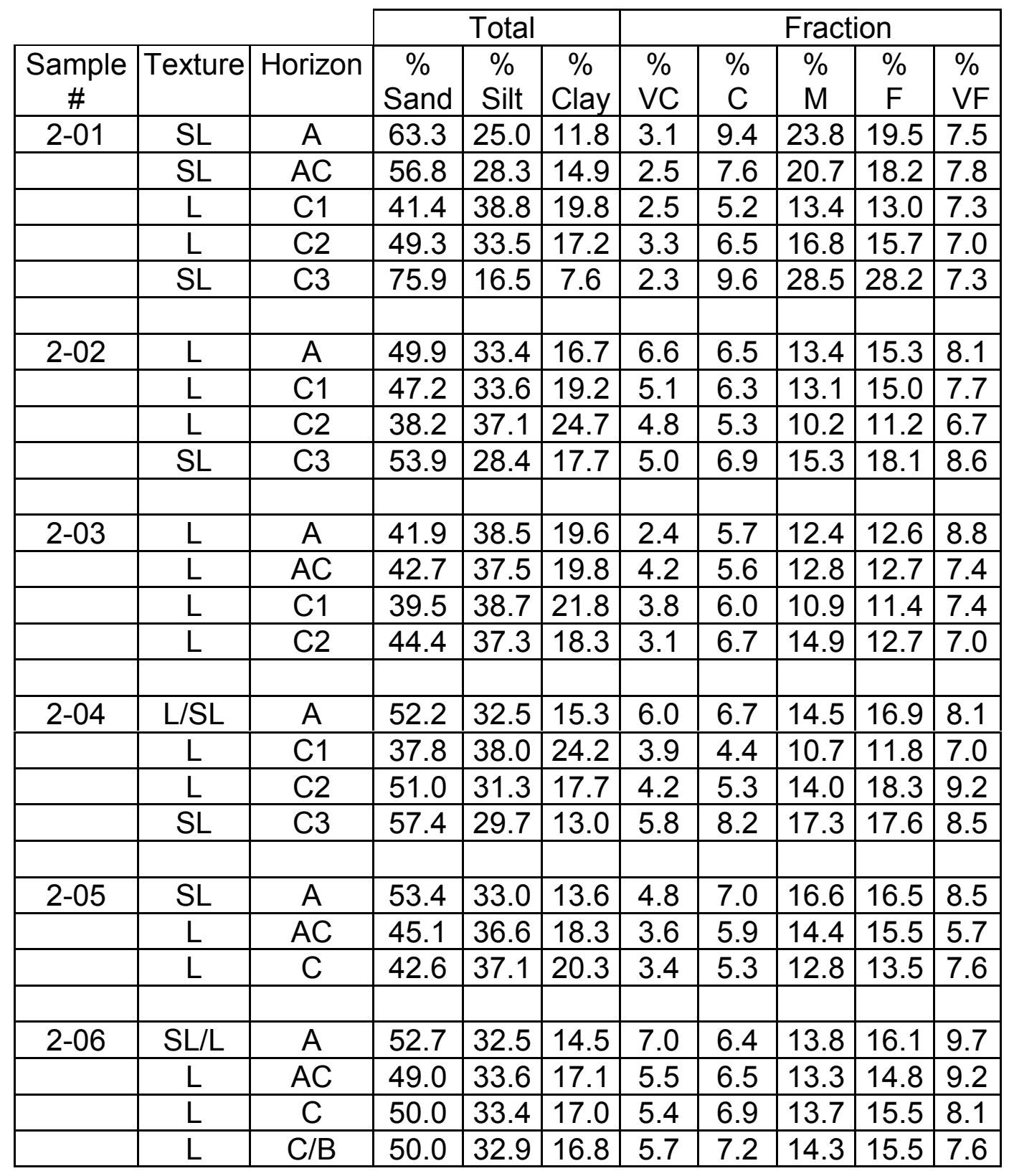




\begin{tabular}{|l|c|c|c|c|c|c|c|c|c|c|}
\cline { 5 - 11 } \multicolumn{1}{c|}{} & \multicolumn{4}{c|}{ Total } & \multicolumn{5}{c|}{ Fraction } \\
\hline \multirow{2}{*}{ Sample \# } & \multirow{2}{*}{ Texture } & \multirow{2}{*}{ Horizon } & $\begin{array}{c}\% \\
\text { Sand }\end{array}$ & $\begin{array}{c}\% \\
\text { Silt }\end{array}$ & $\begin{array}{c}\% \\
\text { Clay }\end{array}$ & $\begin{array}{c}\% \\
\text { VC }\end{array}$ & $\begin{array}{c}\% \\
\text { C }\end{array}$ & $\begin{array}{c}\text { M } \\
\text { F }\end{array}$ & $\begin{array}{c}\% \\
\text { VF }\end{array}$ \\
\hline Native\#1 & SIL & A & 15.6 & 61.5 & 23.0 & 1.2 & 2.3 & 3.6 & 5.0 & 3.5 \\
\hline & SIL & BA & 17.9 & 59.0 & 23.0 & 1.1 & 2.0 & 3.7 & 5.8 & 5.3 \\
\hline & SIL & Bw1 & 16.2 & 59.0 & 24.8 & 1.6 & 1.8 & 2.6 & 4.5 & 5.7 \\
\hline & SIL & Bw2 & 12.2 & 61.9 & 25.9 & 4.0 & 2.5 & 1.4 & 1.6 & 2.7 \\
\hline & & & & & & & & & & \\
\hline Native\#2 & SL & A/E & 65.0 & 28.9 & 6.1 & 1.6 & 7.1 & 26.0 & 23.4 & 6.9 \\
\hline & SL & BA & 72.5 & 19.2 & 8.3 & 3.6 & 10.5 & 29.6 & 22.5 & 6.3 \\
\hline & SL & Bw & 68.0 & 20.7 & 11.3 & 4.4 & 10.2 & 23.8 & 22.4 & 7.2 \\
\hline & SL & BC & 68.3 & 21.1 & 10.6 & 3.4 & 10.2 & 24.2 & 23.7 & 6.8 \\
\hline & & & & & & & & & & \\
\hline Native\#3 & SIL & A & 22.8 & 55.8 & 21.5 & 2.0 & 2.4 & 4.2 & 6.8 & 7.4 \\
\hline & SIL & BA & 26.3 & 53.2 & 20.6 & 2.2 & 2.9 & 4.8 & 8.1 & 8.3 \\
\hline & L & Bw1 & 34.2 & 48.6 & 17.2 & 3.8 & 4.9 & 7.3 & 9.9 & 8.3 \\
\hline & L & Bw2 & 39.3 & 41.2 & 19.5 & 5.2 & 6.2 & 8.8 & 11.3 & 7.8 \\
\hline & L & BC & 48.3 & 34.9 & 16.8 & 5.7 & 8.1 & 12.1 & 14.6 & 7.8 \\
\hline & L & C & 46.4 & 36.9 & 16.7 & 5.6 & 7.2 & 10.7 & 15.0 & 7.9 \\
\hline
\end{tabular}

1. $\mathrm{VC}=$ Very coarse $=2-1 \mathrm{~mm}$

$\mathrm{C}=$ Coarse $=1-0.5 \mathrm{~mm}$

$\mathrm{M}=$ Medium $=0.5-0.250 \mathrm{~mm}$

$\mathrm{F}=$ Fine $=0.250-0.106 \mathrm{~mm}$

$\mathrm{VF}=$ Very fine $=0.106-0.053 \mathrm{~mm}$ 
Table 15. Percent rock fragments by weight for minesoils and native soils.

\begin{tabular}{|c|c|c|c|}
\hline $\begin{array}{c}\text { Sample } \\
\text { ID }\end{array}$ & Horizon & Depth & $\begin{array}{c}\text { Rock } \\
\text { Weight } \\
\%\end{array}$ \\
\hline \multirow[t]{3}{*}{$23-01$} & $\mathrm{~A}$ & $3-7$ & 48.5 \\
\hline & $\overline{\mathrm{AC}}$ & $7-22$ & 40.8 \\
\hline & $\mathrm{C}$ & $22-65$ & 50.3 \\
\hline \multirow[t]{4}{*}{$23-02$} & $\bar{A}$ & $6-13$ & 50.9 \\
\hline & $\overline{\mathrm{Bw}}$ & $13-31$ & 51.0 \\
\hline & $\mathrm{C} / \mathrm{B}$ & $37-75$ & 80.3 \\
\hline & $\mathrm{C}$ & $75-105+$ & 69.7 \\
\hline \multirow[t]{4}{*}{ 23-03 } & $\mathrm{A}$ & $5-12$ & N/A \\
\hline & $\overline{\mathrm{AC}}$ & $12-30$ & 59.7 \\
\hline & $\mathrm{C} 1$ & $30-87$ & 73.3 \\
\hline & $\mathrm{C} 2$ & $87-115+$ & 64.1 \\
\hline \multirow[t]{4}{*}{$23-04$} & $\bar{A}$ & $4-12$ & 60.5 \\
\hline & $\mathrm{AC}$ & $12-38$ & 58.4 \\
\hline & $\mathrm{C}$ & $38-69$ & 55.5 \\
\hline & $\mathrm{C} / \mathrm{B}$ & $69-150+$ & 64.8 \\
\hline \multirow[t]{3}{*}{$23-05$} & A & $3-8$ & 18.4 \\
\hline & $\overline{\mathrm{AC}}$ & $8-26$ & 59.2 \\
\hline & $\mathrm{C} 1$ & $26-61$ & 79.6 \\
\hline \multirow[t]{3}{*}{$23-06$} & $\bar{A}$ & $5-11$ & 60.0 \\
\hline & $\mathrm{Bw}$ & $11-26$ & 83.9 \\
\hline & $\mathrm{C}$ & $26-120+$ & 66.6 \\
\hline
\end{tabular}

\begin{tabular}{|c|c|c|c|}
\hline $\begin{array}{c}\text { Sample } \\
\text { ID }\end{array}$ & Horizon & Depth & $\begin{array}{c}\text { Rock } \\
\text { Weight } \\
\%\end{array}$ \\
\hline \multirow[t]{4}{*}{ 11-01 } & $\mathrm{A}$ & $3-11$ & 30.7 \\
\hline & $\mathrm{AC}$ & $11-37$ & 50.3 \\
\hline & $\mathrm{C} 1$ & $37-89$ & 77.4 \\
\hline & $\mathrm{C} 2$ & $89-160+$ & 62.1 \\
\hline \multirow[t]{4}{*}{ 11-02 } & $\overline{\mathrm{A}}$ & $3-12$ & 37.2 \\
\hline & $\mathrm{AC}$ & $12-41$ & 46.6 \\
\hline & $\mathrm{C} 1$ & $41-75$ & 73.2 \\
\hline & $\mathrm{C} 2$ & $75-125+$ & 73.6 \\
\hline \multirow[t]{5}{*}{ 11-03 } & $\mathrm{A}$ & $0-3$ & 41.4 \\
\hline & $\mathrm{AC}$ & $3-16$ & 63.4 \\
\hline & $\mathrm{C} 1$ & $16-49$ & 77.2 \\
\hline & $\mathrm{C} 2$ & $49-91$ & 70.5 \\
\hline & $\mathrm{C} 3$ & $91-125$ & 75.0 \\
\hline \multirow[t]{5}{*}{ 11-04 } & $\mathrm{A}$ & $2-8$ & 62.8 \\
\hline & $\mathrm{C} 1$ & $8-24$ & 59.0 \\
\hline & $\mathrm{C} 2$ & $24-59$ & 43.3 \\
\hline & $\mathrm{C} 3$ & 59-114 & 53.7 \\
\hline & $\mathrm{C} 4$ & 114-125+ & 56.5 \\
\hline \multirow[t]{5}{*}{$11-05$} & $\mathrm{~A}$ & $0-9$ & 63.9 \\
\hline & $\mathrm{C} 1$ & $9-22$ & 62.0 \\
\hline & $\mathrm{C} 2$ & $22-45$ & 72.9 \\
\hline & $\mathrm{C} 3$ & $45-79$ & 69.6 \\
\hline & $\mathrm{C} 4$ & $79-135+$ & 77.8 \\
\hline \multirow[t]{4}{*}{$11-06$} & $\bar{A}$ & $0-7$ & 59.1 \\
\hline & $\mathrm{Ac}$ & $7-36$ & 53.6 \\
\hline & $\mathrm{CB}$ & $36-72$ & 68.2 \\
\hline & $\mathrm{C}$ & $72-150+$ & 42.8 \\
\hline
\end{tabular}




\begin{tabular}{|c|c|c|c|}
\hline $\begin{array}{c}\text { Sample } \\
\text { ID }\end{array}$ & Horizon & Depth & $\begin{array}{c}\text { Rock } \\
\text { Weight } \\
\%\end{array}$ \\
\hline \multirow[t]{4}{*}{$7-01$} & $\mathrm{~A}$ & $0-8$ & 60.5 \\
\hline & $\mathrm{C} 1 / \mathrm{B}$ & $8-30$ & 75.3 \\
\hline & $\mathrm{C} 2 / \mathrm{B}$ & $30-77$ & 59.1 \\
\hline & $\mathrm{C}$ & $77-125+$ & 65.4 \\
\hline \multirow[t]{5}{*}{$7-02$} & $\bar{A}$ & $2-8$ & 67.9 \\
\hline & $\mathrm{AC}$ & $8-24$ & 59.8 \\
\hline & $\mathrm{C} 1 / \mathrm{B}$ & $24-60$ & 59.2 \\
\hline & $\mathrm{C} 2 / \mathrm{B}$ & $60-107$ & 68.3 \\
\hline & $\mathrm{C}$ & $107-207+$ & 43.3 \\
\hline \multirow[t]{6}{*}{$7-03$} & $\overline{\mathrm{A}}$ & $2-6$ & 54.3 \\
\hline & $\mathrm{AC}$ & $6-28$ & 56.1 \\
\hline & $\mathrm{C} / \mathrm{B}$ & $24-48$ & 68.8 \\
\hline & $\mathrm{C} 1$ & $48-66$ & 76.6 \\
\hline & $\mathrm{C} 2$ & 66-97 & 74.8 \\
\hline & $\mathrm{C} 3$ & $97-160+$ & 84.1 \\
\hline \multirow[t]{5}{*}{$7-04$} & $\mathrm{~A}$ & $0-7$ & 48.8 \\
\hline & $\overline{\mathrm{Bw}}$ & $7-21$ & 42.0 \\
\hline & $\mathrm{C} 1$ & $21-42$ & 68.4 \\
\hline & $\mathrm{C} 2$ & $42-101$ & 58.4 \\
\hline & $\mathrm{C} 3$ & $101-160+$ & 81.3 \\
\hline \multirow[t]{4}{*}{$7-05$} & $\mathrm{~A}$ & $2-7$ & 69.7 \\
\hline & $\mathrm{AC}$ & $7-37$ & 74.0 \\
\hline & $\mathrm{C} 1 / \mathrm{B}$ & $37-92$ & 80.7 \\
\hline & $\mathrm{C} 2 / \mathrm{B}$ & $92-140+$ & 68.2 \\
\hline \multirow[t]{5}{*}{$7-06$} & $\overline{\mathrm{A} 1}$ & $0-10$ & 57.2 \\
\hline & $\mathrm{A} 2$ & $10-19$ & 58.4 \\
\hline & $\mathrm{AC}$ & $19-32$ & 42.9 \\
\hline & $\mathrm{C} 1$ & $32-73$ & 49.7 \\
\hline & $\mathrm{C} 2$ & $73-110+$ & 67.4 \\
\hline
\end{tabular}

\begin{tabular}{|c|c|c|c|}
\hline $\begin{array}{c}\text { Sample } \\
\text { ID }\end{array}$ & Horizon & Depth & $\begin{array}{c}\text { Rock } \\
\text { Weight } \\
\%\end{array}$ \\
\hline \multirow[t]{5}{*}{$2-01$} & $\mathrm{~A}$ & $1-4$ & 93.9 \\
\hline & $\mathrm{AC}$ & $4-10$ & 40.6 \\
\hline & $\mathrm{C} 1$ & $10-41$ & 55.8 \\
\hline & $\mathrm{C} 2$ & $41-92$ & 69.1 \\
\hline & $\mathrm{C} 3$ & $92-150+$ & 52.3 \\
\hline \multirow[t]{4}{*}{$2-02$} & A & $2-6$ & 53.6 \\
\hline & $\mathrm{C} 1$ & $6-51$ & 63.9 \\
\hline & $\mathrm{C} 2$ & 51-104 & 61.9 \\
\hline & $\mathrm{C} 3$ & 104-140+ & 44.4 \\
\hline \multirow{4}{*}{$2-03$} & $\bar{A}$ & $1-7$ & 47.6 \\
\hline & $\mathrm{AC}$ & $7-13$ & 47.1 \\
\hline & $\mathrm{C} 1$ & $13-56$ & 67.8 \\
\hline & $\mathrm{C} 2$ & $56-82$ & 49.1 \\
\hline \multirow[t]{4}{*}{$2-04$} & A & $1-7$ & 62.1 \\
\hline & $\mathrm{C} 1$ & $7-37$ & 51.1 \\
\hline & $\mathrm{C} 2$ & $37-120$ & 83.3 \\
\hline & $\mathrm{C} 3$ & $120-152+$ & 68.8 \\
\hline \multirow[t]{3}{*}{$2-05$} & A & $1-5$ & 25.2 \\
\hline & $\mathrm{AC}$ & $5-22$ & 39.7 \\
\hline & $\mathrm{C}$ & $22-64$ & 74.6 \\
\hline \multirow[t]{4}{*}{$2-06$} & $\mathrm{~A}$ & $2-8$ & 46.2 \\
\hline & $\mathrm{AC}$ & $8-14$ & 63.0 \\
\hline & $\mathrm{C} / \mathrm{B}$ & $14-29$ & 73.5 \\
\hline & $\mathrm{C}$ & $29-120+$ & 69.4 \\
\hline
\end{tabular}




\begin{tabular}{|c|c|c|c|}
\hline $\begin{array}{c}\text { Sample } \\
\text { ID }\end{array}$ & Horizon & Depth & $\begin{array}{c}\text { Rock } \\
\text { Weight } \\
\%\end{array}$ \\
\hline Native\#1 & A & $0-9$ & 13.4 \\
\hline & BA & $9-18$ & 53.4 \\
\hline & Bw1 & $18-43$ & 40.0 \\
\hline & Bw2 & $43-67$ & 69.2 \\
\hline & & & \\
\hline Native\#2 & A/E & $2-5$ & 35.90 \\
\hline & BA & $5-23$ & 40.59 \\
\hline & Bw & $23-59$ & 75.09 \\
\hline & BC & $59-88$ & 81.10 \\
\hline & & & 62.87 \\
\hline Native\#3 & A & $0.5-3$ & 5.17 \\
\hline & BA & $3-6$ & 52.49 \\
\hline & Bw1 & $6-30$ & 77.93 \\
\hline & Bw2 & $30-41$ & 90.38 \\
\hline & BC & $41-53$ & 80.05 \\
\hline & C & $53-65+$ & 88.33 \\
\hline
\end{tabular}


Appendix C

Soil Chemical Properties 
Table 16. Exchangeable Al, barium chloride acidity and calculated chemical data from minesoils and native soils.

\begin{tabular}{|c|c|c|c|c|c|c|c|c|c|c|}
\hline $\begin{array}{l}\text { Sample } \\
\text { I.D. }\end{array}$ & Horizon & $\begin{array}{c}\mathrm{KCl} \\
\mathrm{AL}\end{array}$ & $\begin{array}{c}\mathrm{NH}_{4} \mathrm{OAC} \\
\text { Bases }\end{array}$ & $\begin{array}{c}\text { BaCl } \\
\text { Acidity }\end{array}$ & $\begin{array}{c}\text { CEC- } \\
7\end{array}$ & $\begin{array}{l}\text { CEC- } \\
8.2\end{array}$ & ECEC & $\begin{array}{c}\text { Base } \\
\text { Sat.-7 }\end{array}$ & $\mid \begin{array}{c}\text { Base } \\
\text { Sat.-8.2 }\end{array}$ & $\begin{array}{l}\text { Al } \\
\text { Sat. }\end{array}$ \\
\hline & & \multicolumn{6}{|c|}{ 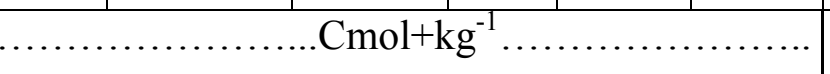 } & \multicolumn{3}{|c|}{$\% \ldots \ldots \ldots$} \\
\hline \multirow[t]{3}{*}{$23-01$} & A & 2.8 & 3.7 & 13.0 & 15.5 & 16.6 & 6.5 & 23.7 & 22.1 & 43.2 \\
\hline & $A C$ & 3.3 & 2.2 & 11.4 & \begin{tabular}{|l|}
11.9 \\
\end{tabular} & 13.6 & 5.5 & 18.6 & 16.3 & 60.0 \\
\hline & $\mathrm{C}$ & 3.5 & 2.4 & 9.8 & 12.7 & 12.2 & 5.8 & 18.5 & 19.3 & 59.6 \\
\hline \multirow[t]{4}{*}{$23-02$} & A & 1.6 & 3.7 & 7.3 & 8.5 & 10.9 & 5.3 & 43.1 & 33.5 & 30.5 \\
\hline & $\mathrm{AC}$ & 0.9 & 4.3 & 5.1 & 7.6 & 9.4 & 5.2 & 56.4 & 45.7 & 16.6 \\
\hline & $\mathrm{C} / \mathrm{B}$ & 0.2 & 2.4 & 2.5 & 2.7 & 4.9 & 2.6 & 90.3 & 49.6 & 7.3 \\
\hline & C & 0.1 & 3.3 & 2.3 & 3.2 & 5.6 & 3.4 & 103.4 & 59.2 & 1.6 \\
\hline \multirow[t]{4}{*}{$23-03$} & A & 1.4 & 8.1 & 10.7 & 15.5 & 18.8 & 9.5 & \begin{tabular}{|l|}
52.2 \\
\end{tabular} & 43.0 & 14.8 \\
\hline & $A C$ & 0.0 & 7.8 & 4.8 & 7.3 & 12.5 & 7.8 & 106.7 & 62.1 & 0.0 \\
\hline & C1 & 0.5 & 6.8 & 4.1 & 6.1 & 10.9 & 7.2 & 110.8 & 62.2 & 6.3 \\
\hline & C2 & 0.3 & 5.4 & 4.2 & 5.9 & 9.6 & 5.7 & \begin{tabular}{|l|}
91.3 \\
\end{tabular} & 56.1 & 5.7 \\
\hline \multirow[t]{4}{*}{ 23-04 } & $A$ & 1.9 & 3.8 & 7.3 & 7.6 & 11.1 & 5.7 & 50.7 & 34.5 & 33.1 \\
\hline & AC & 0.3 & 3.5 & 3.9 & 5.4 & 7.4 & 3.8 & \begin{tabular}{|l|l|}
63.9 \\
\end{tabular} & 47.0 & 8.8 \\
\hline & C & 0.0 & 3.8 & 2.8 & 4.1 & 6.6 & 3.8 & 91.9 & 57.5 & 0.6 \\
\hline & $\mathrm{C} / \mathrm{B}$ & 0.2 & 4.3 & 4.5 & 8.1 & 8.7 & 4.4 & 52.7 & 48.8 & 4.1 \\
\hline \multirow[t]{3}{*}{$23-05$} & A & 1.3 & 4.3 & 3.3 & 4.5 & 7.7 & 5.6 & 95.8 & 56.4 & 23.2 \\
\hline & AC & 0.0 & 5.4 & 3.7 & 4.5 & 9.1 & 5.4 & 118.3 & $\begin{array}{l}58.9 \\
\end{array}$ & 0.0 \\
\hline & C1 & 0.2 & 5.6 & 1.5 & 4.5 & 7.1 & $\begin{array}{l}5.8 \\
\end{array}$ & 125.4 & 78.9 & 3.8 \\
\hline \multirow[t]{3}{*}{ 23-06 } & $\bar{A}$ & 1.6 & 5.0 & 7.2 & 7.4 & 12.1 & 6.6 & $\begin{array}{l}66.7 \\
\end{array}$ & 40.8 & 24.4 \\
\hline & Bw & 0.2 & 5.4 & 5.6 & 6.8 & 10.9 & 5.6 & 79.1 & 49.1 & 3.4 \\
\hline & $C$ & 0.0 & 8.1 & 3.7 & 6.3 & 11.8 & 8.1 & 128.0 & 68.5 & 0.0 \\
\hline
\end{tabular}




\begin{tabular}{|c|c|c|c|c|c|c|c|c|c|c|}
\hline $\begin{array}{c}\text { Sample } \\
\text { I.D. }\end{array}$ & Horizon & $\begin{array}{c}\mathrm{KCl} \\
\mathrm{AL}\end{array}$ & $\begin{array}{c}\mathrm{NH}_{4} \mathrm{OAC} \\
\text { Bases }\end{array}$ & $\begin{array}{c}\mathrm{BaCl} \\
\text { Acidity }\end{array}$ & $\begin{array}{c}\mathrm{CEC}- \\
7\end{array}$ & $\begin{array}{c}\text { CEC- } \\
8.2\end{array}$ & $\mathrm{ECEC}$ & $\begin{array}{c}\% \\
\text { Base } \\
\text { Sat.-7 }\end{array}$ & $\begin{array}{c}\% \\
\text { Base } \\
\text { Sat.-8.2 }\end{array}$ & $\begin{array}{c}\% \\
\text { Al } \\
\text { Sat. }\end{array}$ \\
\hline & & $\ldots \ldots \ldots \ldots \ldots \ldots \ldots . \mathrm{Cmol}+\mathrm{kg}^{-1} \ldots \ldots \ldots \ldots \ldots \ldots \ldots$ & $\ldots \ldots \ldots \ldots . . \ldots \ldots \ldots$ \\
\hline $11-01$ & $\mathrm{~A}$ & 0.3 & 4.2 & 3.2 & 4.4 & 7.4 & 4.5 & 95.7 & 56.5 & 6.9 \\
\hline & $\mathrm{AC}$ & 0.4 & 5.4 & 2.3 & 5.4 & 7.6 & 5.7 & 99.2 & 70.1 & 6.8 \\
\hline & $\mathrm{C} 1$ & 0.3 & 2.5 & 1.4 & 3.6 & 3.9 & 2.8 & 68.4 & 63.9 & 10.5 \\
\hline & $\mathrm{C} 2$ & 0.09 & 2.4 & 1.1 & 4.6 & 3.6 & 2.5 & 53.5 & 68.3 & 3.4 \\
\hline & & & & & & & & & & \\
\hline $11-02$ & $\mathrm{~A}$ & 0.6 & 1.6 & 6.3 & 5.8 & 7.9 & 2.2 & 26.9 & 19.9 & 27.0 \\
\hline & $\mathrm{AC}$ & 0.7 & 1.1 & 5.0 & 5.0 & 6.0 & 1.7 & 21.3 & 17.8 & 38.0 \\
\hline & $\mathrm{C} 1$ & 0.0 & 2.2 & 3.6 & 4.7 & 5.8 & 2.2 & 46.3 & 38.0 & 1.0 \\
\hline & $\mathrm{C} 2$ & 0.0 & 1.9 & 2.1 & 3.7 & 4.0 & 2.0 & 51.8 & 47.9 & 2.2 \\
\hline & & & & & & & & & & \\
\hline $11-03$ & $\mathrm{~A}$ & 0.1 & 2.9 & 2.9 & 4.9 & 5.8 & 3.0 & 58.0 & 49.6 & 3.6 \\
\hline & $\mathrm{AC}$ & 0.1 & 3.2 & 1.4 & 3.4 & 4.6 & 3.3 & 93.6 & 70.4 & 2.3 \\
\hline & $\mathrm{C} 1$ & 0.1 & 3.8 & 1.0 & 2.3 & 4.8 & 3.9 & 163.6 & 79.4 & 2.4 \\
\hline & $\mathrm{C} 2$ & 0.1 & 3.2 & 2.9 & 4.9 & 6.1 & 3.3 & 66.2 & 52.5 & 2.3 \\
\hline & $\mathrm{C} 3$ & 0.1 & 3.4 & 3.8 & 6.5 & 7.2 & 3.4 & 52.0 & 46.9 & 1.8 \\
\hline & & & & & & & & & & \\
\hline $11-04$ & $\mathrm{~A}$ & 0.1 & 1.5 & 3.4 & 3.4 & 4.9 & 1.6 & 45.0 & 31.2 & 4.6 \\
\hline & $\mathrm{C} 1$ & 0.0 & 1.2 & 2.2 & 2.4 & 3.4 & 1.3 & 52.2 & 36.4 & 1.7 \\
\hline & $\mathrm{C} 2$ & 0.4 & 1.7 & 5.0 & 5.4 & 6.7 & 2.1 & 32.0 & 26.0 & 17.6 \\
\hline & $\mathrm{C} 3$ & 0.3 & 1.6 & 5.9 & 5.3 & 7.5 & 1.9 & 29.9 & 21.4 & 17.1 \\
\hline & $\mathrm{C} 4$ & 0.2 & 1.8 & 4.5 & 5.0 & 6.3 & 2.0 & 35.9 & 28.2 & 9.6 \\
\hline & & & & & & & & & & \\
\hline $11-05$ & $\mathrm{~A}$ & 0.0 & 2.1 & 2.2 & 3.2 & 4.3 & 2.1 & 65.4 & 48.2 & 0.0 \\
\hline & $\mathrm{C} 1$ & 0.0 & 2.6 & 1.6 & 3.3 & 4.3 & 2.7 & 78.9 & 62.0 & 0.4 \\
\hline & $\mathrm{C} 2$ & 0.0 & 3.4 & 2.1 & 2.9 & 5.5 & 3.4 & 117.1 & 61.9 & 0.0 \\
\hline & $\mathrm{C} 3$ & 0.1 & 4.3 & 1.3 & 3.4 & 5.6 & 4.4 & 126.2 & 76.3 & 1.2 \\
\hline & $\mathrm{C} 4$ & 0.1 & 6.0 & 2.1 & 3.8 & 8.1 & 6.1 & 157.6 & 74.3 & 1.6 \\
\hline & & & & & & & & & & \\
\hline & $\mathrm{A}$ & 0.3 & 2.5 & 5.4 & 7.5 & 7.9 & 2.8 & 33.4 & 31.8 & 11.2 \\
\hline & $\mathrm{AC}$ & 0.3 & 2.3 & 5.2 & 6.3 & 7.5 & 2.6 & 36.5 & 30.3 & 11.1 \\
\hline & $\mathrm{CB}$ & 0.2 & 2.8 & 3.5 & 4.8 & 6.3 & 3.0 & 59.1 & 44.7 & 7.9 \\
\hline & 0.14 & 3.2 & 2.1 & 4.2 & 5.3 & 3.3 & 75.5 & 60.2 & 4.1 \\
\hline
\end{tabular}




\begin{tabular}{|c|c|c|c|c|c|c|c|c|c|c|}
\hline \multirow[t]{2}{*}{$\begin{array}{l}\text { Sample } \\
\text { I.D. }\end{array}$} & \multirow[t]{2}{*}{ Horizon } & $\begin{array}{c}\mathrm{KCl} \\
\mathrm{AL}\end{array}$ & $\begin{array}{c}\mathrm{NH}_{4} \mathrm{OAC} \\
\text { Bases }\end{array}$ & $\begin{array}{c}\mathrm{BaCl} \\
\text { Acidity }\end{array}$ & $\begin{array}{c}\text { CEC- } \\
7\end{array}$ & $\begin{array}{c}\text { CEC- } \\
8.2\end{array}$ & ECEC & $\begin{array}{c}\% \\
\text { Base } \\
\text { Sat.-7 }\end{array}$ & $\begin{array}{c}\% \\
\text { Base } \\
\text { Sat.-8.2 }\end{array}$ & \begin{tabular}{|c|}
$\%$ \\
Al \\
Sat.
\end{tabular} \\
\hline & & \multicolumn{6}{|c|}{$\ldots \mathrm{Cmol}+\mathrm{kg}^{-1}}$. & \multicolumn{3}{|c|}{$\ldots \% \ldots \ldots \ldots$} \\
\hline \multirow[t]{4}{*}{ 7-01 } & $\bar{A}$ & 0.15 & 4.7 & 1.8 & 5.4 & 6.5 & 4.9 & 86.9 & 72.4 & 3.2 \\
\hline & C1/B & 0.06 & 4.2 & 1.7 & 4.3 & 5.9 & 4.3 & 96.8 & 70.8 & 1.5 \\
\hline & $\mathrm{C} 2 / \mathrm{B}$ & 0.13 & 3.6 & 0.2 & 3.4 & 3.9 & 3.7 & 107.6 & 93.7 & 3.4 \\
\hline & $C$ & 0.25 & 3.2 & 0.7 & 2.8 & 3.8 & 3.4 & 112.2 & 82.7 & 7.4 \\
\hline \multirow[t]{5}{*}{$7-02$} & $A$ & 0.29 & 3.4 & 2.1 & 5.6 & 5.6 & 3.7 & 61.4 & 61.5 & 7.8 \\
\hline & $\mathrm{AC}$ & 0.23 & 3.0 & 1.1 & 4.2 & 4.2 & 3.3 & \begin{tabular}{|l|}
72.4 \\
\end{tabular} & 72.8 & 7.0 \\
\hline & C1/B & 0.20 & 3.4 & 0.5 & 3.8 & 4.0 & 3.6 & 91.1 & 86.5 & 5.5 \\
\hline & C2/B & 0.20 & 3.2 & 0.8 & 3.9 & 4.1 & 3.4 & \begin{tabular}{|l|l|}
83.4 \\
\end{tabular} & 79.7 & 5.8 \\
\hline & $C$ & 0.21 & 2.4 & 0.4 & 2.9 & 2.8 & 2.6 & 84.2 & 86.9 & 7.9 \\
\hline \multirow[t]{6}{*}{$7-03$} & $A$ & 0.41 & 3.7 & 4.2 & 9.0 & 7.9 & 4.1 & 41.2 & 47.0 & \begin{tabular}{|l|}
9.9 \\
\end{tabular} \\
\hline & AC & 0.68 & 3.3 & 3.8 & 7.9 & 7.1 & 4.0 & 42.4 & 46.9 & 17.0 \\
\hline & $\mathrm{C} / \mathrm{B}$ & 0.55 & 3.1 & 2.1 & 5.0 & 5.3 & 3.7 & 62.9 & 59.5 & 14.9 \\
\hline & C1 & 0.38 & 2.9 & 0.3 & 3.4 & 3.2 & 3.3 & 85.9 & 90.8 & 11.6 \\
\hline & $\mathrm{C} 2$ & 0.33 & 2.9 & 0.1 & 3.2 & 3.0 & 3.3 & 92.2 & 97.6 & 10.2 \\
\hline & $\mathrm{C} 3$ & 0.34 & 2.8 & 0.0 & 3.1 & 2.8 & 3.1 & 92.1 & 99.4 & 10.8 \\
\hline \multirow[t]{5}{*}{ 7-04 } & $A$ & 2.42 & 0.8 & 8.5 & 11.5 & 9.4 & 3.3 & 7.3 & 8.9 & 74.3 \\
\hline & Bw & 2.21 & 0.5 & 8.0 & 12.1 & 8.5 & 2.7 & 4.0 & 5.7 & 82.0 \\
\hline & C1 & 1.12 & 0.2 & 1.5 & 3.2 & 1.8 & 1.4 & 7.6 & 13.9 & 82.1 \\
\hline & $\mathrm{C} 2$ & 1.20 & 0.2 & 1.0 & 2.3 & 1.2 & 1.4 & 8.3 & 16.5 & 86.1 \\
\hline & C3 & 2.06 & 0.7 & 4.0 & 6.7 & 4.7 & 2.8 & 11.1 & 15.6 & 73.6 \\
\hline \multirow[t]{4}{*}{$7-05$} & $A$ & 0.46 & 3.1 & 2.2 & 6.2 & 5.3 & 3.5 & \begin{tabular}{|l|}
49.7 \\
\end{tabular} & 58.2 & 13.0 \\
\hline & $A C$ & 0.44 & 4.6 & 1.0 & 4.4 & 5.7 & 5.0 & 105.0 & 81.5 & \begin{tabular}{|l|}
8.7 \\
\end{tabular} \\
\hline & C1/B & 0.23 & 3.6 & 3.3 & 4.4 & 6.9 & 3.8 & 81.6 & 52.0 & \begin{tabular}{|l|}
6.0 \\
\end{tabular} \\
\hline & $\mathrm{C} 2 / \mathrm{B}$ & 0.25 & 4.1 & 2.8 & 4.5 & 6.9 & 4.4 & \begin{tabular}{|l|}
91.4 \\
\end{tabular} & 60.0 & \begin{tabular}{|l|}
5.7 \\
\end{tabular} \\
\hline \multirow[t]{5}{*}{$7-06$} & A1 & 0.82 & 1.0 & 4.9 & 3.3 & 5.8 & 1.8 & 29.0 & 16.4 & 46.2 \\
\hline & A2 & 1.06 & 0.5 & 3.5 & 2.2 & 4.0 & 1.6 & 24.5 & 13.6 & 66.1 \\
\hline & $\mathrm{AC}$ & 1.13 & 0.8 & 5.3 & 2.4 & 6.1 & 1.9 & 32.1 & 12.9 & 59.0 \\
\hline & C1 & 0.72 & 0.8 & 3.3 & 3.7 & 4.1 & 1.5 & 21.3 & 19.4 & 47.9 \\
\hline & $\mathrm{C} 2$ & 1.10 & 1.3 & 4.0 & 3.1 & 5.3 & 2.4 & 42.2 & 24.5 & 46.1 \\
\hline
\end{tabular}




\begin{tabular}{|c|c|c|c|c|c|c|c|c|c|c|}
\hline $\begin{array}{c}\text { Sample } \\
\text { I.D. }\end{array}$ & Horizon & $\begin{array}{c}\mathrm{KCl} \\
\mathrm{AL}\end{array}$ & $\begin{array}{c}\mathrm{NH}_{4} \mathrm{OAC} \\
\text { Bases }\end{array}$ & $\begin{array}{c}\mathrm{BaCl} \\
\mathrm{Acidity}\end{array}$ & $\begin{array}{c}\mathrm{CEC}- \\
7\end{array}$ & $\begin{array}{c}\mathrm{CEC}- \\
8.2\end{array}$ & $\mathrm{ECEC}$ & $\begin{array}{c}\% \\
\text { Base } \\
\text { Sat.-7 }\end{array}$ & $\begin{array}{c}\% \\
\text { Sat.-8.2 }\end{array}$ & $\begin{array}{c}\% \\
\text { Al } \\
\text { Sat. }\end{array}$ \\
\hline & & $\ldots \ldots \ldots \ldots \ldots \ldots \ldots . \mathrm{Cmol}+\mathrm{kg}^{-1} \ldots \ldots \ldots \ldots \ldots \ldots \ldots$ & $\ldots \ldots \ldots \ldots \ldots \ldots \ldots$ \\
\hline $2-01$ & $\mathrm{~A}$ & 0.59 & 2.5 & 3.5 & 3.9 & 6.1 & 3.1 & 65.6 & 41.9 & 18.7 \\
\hline & $\mathrm{AC}$ & 0.57 & 3.1 & 3.8 & 5.5 & 7.0 & 3.7 & 57.5 & 45.0 & 15.3 \\
\hline & $\mathrm{C} 1$ & 0.75 & 5.9 & 6.3 & 13.3 & 12.2 & 6.7 & 44.4 & 48.4 & 11.2 \\
\hline & $\mathrm{C} 2$ & 0.66 & 6.4 & 5.8 & 13.0 & 12.2 & 7.1 & 49.2 & 52.6 & 9.3 \\
\hline & $\mathrm{C} 3$ & 0.32 & 1.9 & 2.4 & 1.6 & 4.4 & 2.3 & 120.9 & 44.6 & 14.0 \\
\hline & & & & & & & & & & \\
\hline $2-02$ & $\mathrm{~A}$ & 0.20 & 7.1 & 3.8 & 6.8 & 10.9 & 7.3 & 104.1 & 65.2 & 2.7 \\
\hline & $\mathrm{C} 1$ & 0.19 & 8.1 & 2.2 & 7.1 & 10.3 & 8.3 & 114.6 & 78.8 & 2.3 \\
\hline & $\mathrm{C} 2$ & 0.46 & 7.6 & 5.8 & 9.8 & 13.4 & 8.1 & 77.4 & 56.6 & 5.7 \\
\hline & $\mathrm{C} 3$ & 0.24 & 7.1 & 3.4 & 6.3 & 10.5 & 7.3 & 111.4 & 67.4 & 3.3 \\
\hline & & & & & & & & & & \\
\hline $2-03$ & $\mathrm{~A}$ & 0.33 & 6.7 & 3.7 & 7.0 & 10.4 & 7.1 & 96.2 & 64.6 & 4.7 \\
\hline & $\mathrm{AC}$ & 0.25 & 7.8 & 2.6 & 6.5 & 10.3 & 8.0 & 119.5 & 75.1 & 3.1 \\
\hline & $\mathrm{C} 1$ & 0.19 & 7.6 & 4.2 & 8.7 & 11.8 & 7.7 & 87.2 & 64.2 & 2.4 \\
\hline & $\mathrm{C} 2$ & 1.27 & 3.5 & 5.3 & 7.9 & 8.8 & 4.7 & 43.8 & 39.4 & 26.9 \\
\hline & & & & & & & & & & \\
\hline $2-04$ & $\mathrm{~A}$ & 0.28 & 8.4 & 2.1 & 7.1 & 10.5 & 8.6 & 118.5 & 79.9 & 3.2 \\
\hline & $\mathrm{C} 1$ & 0.28 & 8.0 & 4.8 & 9.3 & 12.8 & 8.2 & 86.0 & 62.3 & 3.4 \\
\hline & $\mathrm{C} 2$ & 0.29 & 4.4 & 2.2 & 5.2 & 6.6 & 4.7 & 84.8 & 66.8 & 6.2 \\
\hline & $\mathrm{C} 3$ & 0.24 & 3.3 & 2.2 & 4.3 & 5.4 & 3.5 & 75.3 & 60.2 & 6.9 \\
\hline & & & & & & & & & & \\
\hline $2-05$ & $\mathrm{~A}$ & 0.23 & 4.0 & 4.2 & 7.3 & 8.2 & 4.3 & 55.0 & 49.1 & 5.4 \\
\hline & $\mathrm{AC}$ & 0.23 & 6.0 & 2.6 & 7.7 & 8.6 & 6.3 & 78.0 & 69.8 & 3.7 \\
\hline & $\mathrm{C}$ & 0.39 & 4.2 & 2.1 & 7.3 & 6.3 & 4.6 & 57.8 & 67.1 & 8.4 \\
\hline & & & & & & & & & & \\
\hline & $\mathrm{A}$ & 0.29 & 4.1 & 2.4 & 6.1 & 6.5 & 4.4 & 67.5 & 63.0 & 6.7 \\
\hline & $\mathrm{C} / \mathrm{B}$ & 0.19 & 3.7 & 2.5 & 5.6 & 6.2 & 3.9 & 66.1 & 60.0 & 4.8 \\
\hline & $\mathrm{C}$ & 0.22 & 4.1 & 2.3 & 5.8 & 6.4 & 4.3 & 70.2 & 64.2 & 5.0 \\
\hline
\end{tabular}




\begin{tabular}{|c|c|c|c|c|c|c|c|c|c|c|}
\hline $\begin{array}{l}\text { Sample } \\
\text { I.D. }\end{array}$ & Horizon & $\begin{array}{c}\mathrm{KCl} \\
\mathrm{AL}\end{array}$ & $\begin{array}{c}\mathrm{NH}_{4} \mathrm{OAC} \\
\text { Bases }\end{array}$ & $\begin{array}{c}\mathrm{BaCl} \\
\text { Acidity }\end{array}$ & $\begin{array}{c}\text { CEC- } \\
7\end{array}$ & $\begin{array}{c}\text { CEC- } \\
8.2\end{array}$ & ECEC & $\begin{array}{c}\% \\
\text { Base } \\
\text { Sat.-7 }\end{array}$ & $\begin{array}{c}\% \\
\text { Base } \\
\text { Sat.-8.2 }\end{array}$ & $\begin{array}{c}\% \\
\text { Al } \\
\text { Sat. }\end{array}$ \\
\hline & & \multicolumn{6}{|c|}{ 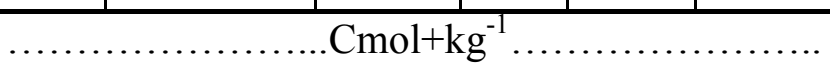 } & \multicolumn{3}{|c|}{...........\%....... } \\
\hline \multirow[t]{4}{*}{ Native\#1 } & A & 1.3 & 6.2 & 17.4 & 19.4 & 23.5 & 7.4 & 31.7 & 26.2 & 16.9 \\
\hline & $\overline{\mathrm{BA}}$ & 3.0 & 1.2 & 11.6 & 10.6 & 12.8 & 4.2 & 11.6 & 9.7 & 70.8 \\
\hline & Bw1 & 2.8 & 0.9 & 8.0 & 7.7 & 9.0 & 3.8 & 12.2 & 10.6 & 74.9 \\
\hline & Bw2 & 2.3 & - & 6.9 & 7.8 & 8.9 & 4.2 & 25.2 & 22.3 & 53.4 \\
\hline \multirow[t]{4}{*}{ Native\#2 } & $\mathrm{A} / \mathrm{E}$ & 2.9 & 1.9 & 21.3 & 22.0 & 23.2 & 4.8 & 8.4 & 8.0 & 61.3 \\
\hline & $\overline{\mathrm{BA}}$ & 1.8 & 0.1 & 3.1 & 3.3 & 3.2 & 1.9 & 2.2 & 2.3 & 96.2 \\
\hline & $\mathrm{Bw}$ & 2.1 & 0.1 & 3.8 & 3.2 & 3.9 & 2.2 & 2.0 & 1.7 & 97.1 \\
\hline & $\overline{\mathrm{BC}}$ & 2.0 & 0.1 & 3.2 & 2.9 & 3.3 & 2.1 & 4.0 & 3.6 & 94.4 \\
\hline \multirow[t]{6}{*}{ Native\#3 } & A & 0.8 & 11.9 & 14.3 & 25.7 & 26.2 & 12.7 & 46.4 & 45.5 & 6.6 \\
\hline & $\overline{\mathrm{BA}}$ & 2.7 & 2.8 & 12.7 & 12.4 & 15.5 & 5.5 & 22.5 & 18.0 & 49.0 \\
\hline & Bw1 & 3.4 & 1.0 & 8.4 & 7.6 & 9.4 & 4.4 & 13.2 & 10.6 & 77.1 \\
\hline & Bw2 & 3.7 & 1.5 & 6.8 & 8.2 & 8.3 & 5.3 & 18.8 & 18.4 & 70.9 \\
\hline & $\mathrm{BC}$ & 3.0 & 1.7 & 6.1 & 7.2 & 7.8 & 4.7 & 24.2 & 22.2 & 63.0 \\
\hline & $\mathrm{C}$ & 2.5 & 2.2 & 5.4 & 7.3 & 7.6 & 4.7 & 29.7 & 28.7 & 53.8 \\
\hline
\end{tabular}


Table 17. Percent $\mathrm{C}, \mathrm{S}, \mathrm{N}$ and ammonium acetate extractable bases of Minesoils and Native Soils.

\begin{tabular}{|c|c|c|c|c|c|c|c|c|}
\hline $\begin{array}{c}\text { Sample } \\
\text { I.D. }\end{array}$ & Horizon & $\begin{array}{c}\text { Carbon } \\
\%\end{array}$ & $\begin{array}{c}\text { Sulfur } \\
\%\end{array}$ & $\begin{array}{c}\text { Nitrogen } \\
\%\end{array}$ & $\begin{array}{c}\mathrm{Ca} \\
\mathrm{cmol}(+) / \\
\mathrm{kg}\end{array}$ & $\begin{array}{c}\mathrm{Mg} \\
\mathrm{cmol}(+) / \\
\mathrm{kg}\end{array}$ & $\begin{array}{c}\mathrm{Na} \\
\mathrm{cmol}(+) / \\
\mathrm{kg}\end{array}$ & $\begin{array}{c}\mathrm{K} \\
\mathrm{cmol}(+) / \\
\mathrm{kg}\end{array}$ \\
\hline $23-01$ & $\mathrm{~A}$ & 5.35 & 0.07 & 0.28 & 1.7 & 1.5 & 0.0 & 0.4 \\
\hline & $\mathrm{AC}$ & 2.22 & 0.05 & 0.10 & 0.8 & 1.0 & 0.1 & 0.4 \\
\hline & $\mathrm{C}$ & 3.33 & 0.04 & 0.09 & 0.6 & 1.5 & 0.0 & 0.2 \\
\hline & & & & & & & & \\
\hline $23-02$ & $\mathrm{~A}$ & 2.54 & 0.05 & 0.03 & 1.9 & 1.6 & 0.0 & 0.2 \\
\hline & $\mathrm{AC}$ & 2.96 & 0.05 & 0.02 & 1.9 & 2.3 & 0.0 & 0.0 \\
\hline & $\mathrm{C} / \mathrm{B}$ & 1.28 & 0.02 & 0.00 & 1.0 & 1.4 & 0.0 & 0.0 \\
\hline & $\mathrm{C}$ & 0.85 & 0.03 & 0.00 & 1.8 & 1.5 & 0.0 & 0.0 \\
\hline & & & & & & & & \\
\hline $23-03$ & $\mathrm{~A}$ & 2.20 & 0.04 & 0.02 & 4.8 & 3.2 & 0.0 & 0.1 \\
\hline & $\mathrm{AC}$ & 3.98 & 0.07 & 0.05 & 4.6 & 3.0 & 0.1 & 0.1 \\
\hline & $\mathrm{C} 1$ & 7.99 & 0.19 & 0.07 & 3.4 & 3.3 & 0.1 & 0.1 \\
\hline & $\mathrm{C} 2$ & 5.12 & 0.17 & 0.08 & 2.7 & 2.6 & 0.1 & 0.1 \\
\hline & & & & & & & & \\
\hline $23-04$ & $\mathrm{~A}$ & 2.25 & 0.03 & 0.04 & 2.6 & 1.2 & 0.0 & 0.0 \\
\hline & $\mathrm{AC}$ & 1.17 & 0.03 & 0.02 & 2.3 & 1.2 & 0.0 & 0.0 \\
\hline & $\mathrm{C}$ & 0.98 & 0.03 & 0.00 & 2.4 & 1.4 & 0.0 & 0.0 \\
\hline & $\mathrm{C} / \mathrm{B}$ & 1.08 & 0.02 & 0.01 & 2.5 & 1.8 & 0.0 & 0.0 \\
\hline & & & & & & & & \\
\hline $23-05$ & $\mathrm{~A}$ & 2.56 & 0.04 & 0.04 & 2.8 & 1.5 & 0.0 & 0.0 \\
\hline & $\mathrm{AC}$ & 2.92 & 0.07 & 0.02 & 3.3 & 2.1 & 0.0 & 0.0 \\
\hline & $\mathrm{C} 1$ & 1.13 & 0.04 & 0.01 & 3.3 & 2.3 & 0.0 & 0.0 \\
\hline & & & & & & & & \\
\hline $23-06$ & $\mathrm{~A}$ & 1.83 & 0.02 & 0.05 & 3.3 & 1.5 & 0.0 & 0.1 \\
\hline & $\mathrm{Bw}$ & 1.40 & 0.04 & 0.03 & 3.2 & 2.0 & 0.0 & 0.1 \\
\hline & $\mathrm{C}$ & 1.48 & 0.04 & 0.02 & 4.6 & 3.3 & 0.0 & 0.1 \\
\hline
\end{tabular}




\begin{tabular}{|c|c|c|c|c|c|c|c|c|}
\hline $\begin{array}{c}\text { Sample } \\
\text { I.D. }\end{array}$ & Horizon & $\begin{array}{c}\text { Carbon } \\
\%\end{array}$ & $\begin{array}{c}\text { Sulfur } \\
\%\end{array}$ & $\begin{array}{c}\text { Nitrogen } \\
\%\end{array}$ & $\begin{array}{c}\mathrm{Ca} \\
\mathrm{cmol}(+) / \\
\mathrm{kg}\end{array}$ & $\begin{array}{c}\mathrm{Mg} \\
\mathrm{cmol}(+) / \\
\mathrm{kg}\end{array}$ & $\begin{array}{c}\mathrm{Na} \\
\mathrm{cmol}(+) / \\
\mathrm{kg}\end{array}$ & $\begin{array}{c}\mathrm{K} \\
\mathrm{cmol}(+) / \\
\mathrm{kg}\end{array}$ \\
\hline $11-01$ & $\mathrm{~A}$ & 2.47 & 0.04 & 0.03 & 2.5 & 1.7 & 0.0 & 0.1 \\
\hline & $\mathrm{AC}$ & 3.92 & 0.08 & 0.03 & 3.0 & 2.4 & 0.0 & 0.0 \\
\hline & $\mathrm{C} 1$ & 2.09 & 0.05 & 0.03 & 1.8 & 0.7 & 0.0 & 0.0 \\
\hline & $\mathrm{C} 2$ & 5.26 & 0.11 & 0.05 & 1.7 & 0.7 & 0.0 & 0.1 \\
\hline & & & & & & & & \\
\hline $11-02$ & $\mathrm{~A}$ & 1.03 & 0.03 & 0.03 & 1.0 & 0.4 & 0.0 & 0.1 \\
\hline & $\mathrm{AC}$ & 0.72 & 0.03 & 0.01 & 0.6 & 0.3 & 0.0 & 0.1 \\
\hline & $\mathrm{C} 1$ & 4.79 & 0.06 & 0.03 & 1.5 & 0.7 & 0.0 & 0.1 \\
\hline & $\mathrm{C} 2$ & 4.67 & 0.07 & 0.04 & 1.2 & 0.6 & 0.0 & 0.1 \\
\hline & & & & & & & & \\
\hline $11-03$ & $\mathrm{~A}$ & 3.09 & 0.06 & 0.04 & 2.0 & 0.7 & 0.0 & 0.1 \\
\hline & $\mathrm{AC}$ & 3.66 & 0.09 & 0.03 & 2.4 & 0.7 & 0.0 & 0.1 \\
\hline & $\mathrm{C} 1$ & 6.93 & 0.11 & 0.02 & 3.1 & 0.7 & 0.0 & 0.1 \\
\hline & $\mathrm{C} 2$ & 2.09 & 0.05 & 0.00 & 2.3 & 0.8 & 0.0 & 0.1 \\
\hline & $\mathrm{C} 3$ & 2.31 & 0.06 & 0.01 & 2.1 & 1.2 & 0.0 & 0.1 \\
\hline & & & & & & & & \\
\hline $11-04$ & $\mathrm{~A}$ & 1.77 & 0.02 & 0.00 & 1.1 & 0.3 & 0.0 & 0.1 \\
\hline & $\mathrm{C} 1$ & 1.24 & 0.02 & 0.00 & 0.9 & 0.3 & 0.0 & 0.0 \\
\hline & $\mathrm{C} 2$ & 0.83 & 0.03 & 0.00 & 1.1 & 0.6 & 0.0 & 0.1 \\
\hline & $\mathrm{C} 3$ & 0.63 & 0.03 & 0.00 & 1.0 & 0.6 & 0.0 & 0.1 \\
\hline & $\mathrm{C} 4$ & 0.49 & 0.03 & 0.00 & 1.2 & 0.5 & 0.0 & 0.1 \\
\hline & & & & & & & & \\
\hline $11-05$ & $\mathrm{~A}$ & 2.28 & 0.05 & 0.00 & 1.6 & 0.4 & 0.0 & 0.0 \\
\hline & $\mathrm{C} 1$ & 2.15 & 0.05 & 0.00 & 2.0 & 0.6 & 0.0 & 0.0 \\
\hline & $\mathrm{C} 2$ & 2.33 & 0.08 & 0.00 & 2.7 & 0.6 & 0.0 & 0.0 \\
\hline & $\mathrm{C} 3$ & 3.49 & 0.06 & 0.00 & 3.5 & 0.7 & 0.0 & 0.1 \\
\hline & $\mathrm{C} 4$ & 4.12 & 0.11 & 0.01 & 5.0 & 0.9 & 0.0 & 0.1 \\
\hline & & & & & & & & \\
\hline & $\mathrm{A}$ & 1.99 & 0.03 & 0.00 & 1.8 & 0.6 & 0.0 & 0.1 \\
\hline & $\mathrm{Ac}$ & 1.13 & 0.03 & 0.00 & 1.7 & 0.6 & 0.0 & 0.1 \\
\hline & $\mathrm{CB}$ & 2.62 & 0.04 & 0.00 & 1.3 & 1.3 & 0.1 & 0.1 \\
\hline & $\mathrm{C}$ & 2.14 & 0.05 & 0.00 & 1.5 & 1.5 & 0.1 & 0.1 \\
\hline
\end{tabular}




\begin{tabular}{|c|c|c|c|c|c|c|c|c|}
\hline $\begin{array}{c}\text { Sample } \\
\text { I.D. }\end{array}$ & Horizon & $\begin{array}{c}\text { Carbon } \\
\%\end{array}$ & $\begin{array}{c}\text { Sulfur } \\
\%\end{array}$ & $\begin{array}{c}\text { Nitrogen } \\
\%\end{array}$ & $\begin{array}{c}\mathrm{Ca} \\
\mathrm{cmol}(+) / \\
\mathrm{kg}\end{array}$ & $\begin{array}{c}\mathrm{Mg} \\
\mathrm{cmol}(+) / \\
\mathrm{kg}\end{array}$ & $\begin{array}{c}\mathrm{Na} \\
\mathrm{cmol}(+) / \\
\mathrm{kg}\end{array}$ & $\begin{array}{c}\mathrm{K} \\
\mathrm{cmol}(+) / \\
\mathrm{kg}\end{array}$ \\
\hline \multirow[t]{4}{*}{$7-01$} & $\bar{A}$ & 4.20 & 0.05 & 0.06 & 2.4 & 1.9 & 0.3 & 0.1 \\
\hline & C1/B & 2.33 & 0.03 & 0.00 & 2.2 & 1.7 & 0.2 & 0.1 \\
\hline & C2/B & 1.98 & 0.03 & 0.00 & 2.0 & 1.5 & 0.1 & 0.0 \\
\hline & $C$ & 1.57 & 0.02 & 0.00 & 1.9 & 1.2 & 0.0 & 0.0 \\
\hline \multirow[t]{5}{*}{ 7-02 } & A & 3.87 & 0.07 & 0.02 & 1.7 & 1.4 & 0.1 & 0.2 \\
\hline & $A C$ & 3.29 & 0.08 & 0.00 & 1.1 & 1.7 & 0.0 & 0.1 \\
\hline & C1/B & 3.88 & 0.06 & 0.00 & 1.5 & 1.8 & 0.1 & 0.1 \\
\hline & $\mathrm{C} 2 / \mathrm{B}$ & 6.71 & 0.09 & 0.02 & 1.1 & 2.0 & 0.1 & 0.1 \\
\hline & C & 3.11 & 0.05 & 0.00 & 1.2 & 1.1 & 0.1 & 0.0 \\
\hline \multirow[t]{6}{*}{ 7-03 } & A & 4.43 & 0.11 & 0.01 & 1.6 & 1.8 & 0.1 & 0.2 \\
\hline & $A C$ & 3.52 & 0.09 & 0.01 & 1.5 & 1.6 & 0.1 & 0.2 \\
\hline & $\mathrm{C} / \mathrm{B}$ & 2.09 & 0.06 & 0.00 & 1.5 & 1.4 & 0.1 & 0.1 \\
\hline & C1 & 0.63 & 0.03 & 0.00 & 1.4 & 1.2 & 0.2 & 0.1 \\
\hline & C2 & 0.71 & 0.03 & 0.00 & 1.5 & 1.3 & 0.1 & 0.1 \\
\hline & C3 & 1.28 & 0.05 & 0.00 & 1.4 & 1.3 & 0.1 & 0.1 \\
\hline \multirow[t]{5}{*}{$7-04$} & $A$ & 3.73 & 0.07 & 0.00 & 0.3 & 0.4 & 0.0 & 0.1 \\
\hline & $\mathrm{Bw}$ & 3.04 & 0.07 & 0.00 & 0.1 & 0.2 & 0.1 & 0.0 \\
\hline & C1 & 0.88 & 0.03 & 0.00 & 0.1 & 0.1 & 0.0 & 0.0 \\
\hline & $\mathrm{C} 2$ & 0.76 & 0.04 & 0.00 & 0.1 & 0.1 & 0.0 & 0.0 \\
\hline & C3 & 1.11 & 0.02 & 0.00 & 0.2 & 0.4 & 0.0 & 0.1 \\
\hline \multirow[t]{4}{*}{$7-05$} & A & 5.11 & 0.12 & 0.05 & 1.4 & 1.4 & 0.1 & 0.2 \\
\hline & $A C$ & 4.79 & 0.16 & 0.02 & 2.3 & 2.2 & 0.0 & 0.1 \\
\hline & C1/B & 6.19 & 0.15 & 0.02 & 1.8 & 1.7 & 0.0 & 0.1 \\
\hline & C2/B & 5.74 & 0.12 & 0.02 & 2.1 & 1.9 & 0.0 & 0.1 \\
\hline \multirow[t]{5}{*}{$7-06$} & A1 & 3.50 & 0.05 & 0.00 & 0.4 & 0.5 & 0.0 & 0.0 \\
\hline & A2 & 1.00 & 0.04 & 0.00 & 0.2 & 0.3 & 0.0 & 0.0 \\
\hline & $A C$ & 2.07 & 0.06 & 0.00 & 0.3 & 0.5 & 0.0 & 0.0 \\
\hline & $\mathrm{C} 1$ & 0.39 & 0.02 & 0.00 & 0.4 & 0.4 & 0.0 & 0.0 \\
\hline & C2 & 0.35 & 0.03 & 0.00 & 0.4 & 0.8 & 0.0 & 0.1 \\
\hline
\end{tabular}




\begin{tabular}{|c|c|c|c|c|c|c|c|c|}
\hline $\begin{array}{l}\text { Sample } \\
\text { I.D. }\end{array}$ & Horizon & $\begin{array}{c}\text { Carbon } \\
\%\end{array}$ & $\begin{array}{l}\text { Sulfur } \\
\%\end{array}$ & $\begin{array}{c}\text { Nitrogen } \\
\%\end{array}$ & $\begin{array}{c}\mathrm{Ca} \\
\mathrm{cmol}(+) / \\
\mathrm{kg}\end{array}$ & $\begin{array}{c}\mathrm{Mg} \\
\mathrm{cmol}(+) / \\
\mathrm{kg}\end{array}$ & $\begin{array}{c}\mathrm{Na} \\
\mathrm{cmol}(+) / \\
\mathrm{kg}\end{array}$ & $\begin{array}{c}\mathrm{K} \\
\mathrm{cmol}(+) \\
/ \mathrm{kg}\end{array}$ \\
\hline \multirow[t]{5}{*}{$2-01$} & A & 1.49 & 0.03 & 0.00 & 1.3 & 1.2 & 0.0 & 0.1 \\
\hline & $\mathrm{AC}$ & 1.46 & 0.03 & 0.00 & 1.2 & 1.8 & 0.0 & 0.1 \\
\hline & $\mathrm{C} 1$ & 4.52 & 0.07 & 0.01 & 2.4 & 3.5 & 0.0 & 0.1 \\
\hline & $\mathrm{C} 2$ & 4.42 & 0.07 & 0.00 & 2.8 & 3.6 & 0.0 & 0.1 \\
\hline & C3 & 0.38 & 0.01 & 0.00 & 0.7 & 1.2 & 0.0 & 0.1 \\
\hline \multirow[t]{4}{*}{$2-02$} & $\mathrm{~A}$ & 5.07 & 0.09 & 0.05 & 3.2 & 3.8 & 0.0 & 0.2 \\
\hline & $\mathrm{C} 1$ & 3.87 & 0.07 & 0.00 & 4.0 & 4.0 & 0.0 & 0.0 \\
\hline & $\mathrm{C} 2$ & 6.40 & 0.13 & 0.01 & 3.7 & 3.8 & 0.0 & 0.1 \\
\hline & $\mathrm{C} 3$ & 4.13 & 0.08 & 0.00 & 3.6 & 3.3 & 0.0 & 0.1 \\
\hline \multirow[t]{4}{*}{$2-03$} & $\mathrm{~A}$ & 2.91 & 0.04 & 0.00 & 2.6 & 4.0 & 0.0 & 0.2 \\
\hline & $\mathrm{AC}$ & 3.47 & 0.04 & 0.00 & 3.3 & 4.2 & 0.0 & 0.2 \\
\hline & $\mathrm{C} 1$ & 6.69 & 0.10 & 0.00 & 3.1 & 4.3 & 0.0 & 0.2 \\
\hline & $\mathrm{C} 2$ & 2.25 & 0.05 & 0.00 & 1.2 & 2.0 & 0.0 & 0.2 \\
\hline \multirow[t]{4}{*}{$2-04$} & $\bar{A}$ & 5.59 & 0.11 & 0.09 & 4.5 & 3.5 & 0.0 & 0.4 \\
\hline & $\mathrm{C} 1$ & 1.48 & 0.04 & 0.00 & 3.8 & 4.0 & 0.0 & 0.1 \\
\hline & $\mathrm{C} 2$ & 1.21 & 0.03 & 0.00 & 2.1 & 2.2 & 0.0 & 0.1 \\
\hline & $\mathrm{C} 3$ & 0.81 & 0.03 & 0.00 & 1.3 & 1.9 & 0.0 & 0.0 \\
\hline \multirow[t]{3}{*}{$2-05$} & $\mathrm{~A}$ & 4.40 & 0.05 & 0.00 & 2.4 & 1.5 & 0.0 & 0.2 \\
\hline & $\overline{\mathrm{AC}}$ & 2.71 & 0.05 & 0.00 & 3.5 & 2.4 & 0.0 & 0.1 \\
\hline & $\mathrm{C}$ & 2.71 & 0.08 & 0.00 & 2.4 & 1.8 & 0.0 & 0.1 \\
\hline \multirow[t]{4}{*}{$2-06$} & $\mathrm{~A}$ & 4.39 & 0.07 & 0.00 & 1.9 & 2.1 & 0.0 & 0.1 \\
\hline & $\mathrm{AC}$ & 3.37 & 0.06 & 0.00 & 1.6 & 2.1 & 0.0 & 0.1 \\
\hline & $\mathrm{C} / \mathrm{B}$ & 4.64 & 0.06 & 0.00 & 1.6 & 2.1 & 0.0 & 0.1 \\
\hline & $\mathrm{C}$ & 3.94 & 0.07 & 0.00 & 1.8 & 2.3 & 0.0 & 0.1 \\
\hline
\end{tabular}




\begin{tabular}{|c|c|c|c|c|c|c|c|c|}
\hline $\begin{array}{c}\text { Sample } \\
\text { I.D. }\end{array}$ & Horizon & $\begin{array}{c}\text { Carbon } \\
\%\end{array}$ & $\begin{array}{c}\text { Sulfur } \\
\%\end{array}$ & $\begin{array}{c}\text { Nitrogen } \\
\%\end{array}$ & $\begin{array}{c}\mathrm{Ca} \\
\mathrm{cmol}(+) / \\
\mathrm{kg}\end{array}$ & $\begin{array}{c}\mathrm{Mg} \\
\mathrm{cmol}(+) / \\
\mathrm{kg}\end{array}$ & $\begin{array}{c}\mathrm{Na} \\
\mathrm{cmol}(+) / \\
\mathrm{kg}\end{array}$ & $\begin{array}{c}\mathrm{K} \\
\mathrm{cmol}(+) / \\
\mathrm{kg}\end{array}$ \\
\hline Native\#1 & $\mathrm{A}$ & 5.63 & 0.06 & 0.15 & 5.3 & 0.7 & 0.0 & 0.2 \\
\hline & $\mathrm{BA}$ & 1.89 & 0.04 & 0.00 & 0.9 & 0.2 & 0.0 & 0.1 \\
\hline & $\mathrm{Bw} 1$ & 0.79 & 0.05 & 0.00 & 0.6 & 0.3 & 0.0 & 0.1 \\
\hline & $\mathrm{Bw} 2$ & 0.76 & 0.04 & 0.00 & 1.1 & 0.8 & 0.0 & 0.1 \\
\hline & & & & & & & & \\
\hline Native\#2 & $\mathrm{A} / \mathrm{E}$ & 7.14 & 0.07 & 0.11 & 1.3 & 0.5 & 0.0 & 0.1 \\
\hline & $\mathrm{BA}$ & 0.51 & 0.04 & 0.00 & 0.0 & 0.0 & 0.0 & 0.0 \\
\hline & $\mathrm{Bw}$ & 0.37 & 0.02 & 0.00 & 0.0 & 0.0 & 0.0 & 0.0 \\
\hline & $\mathrm{BC}$ & 0.35 & 0.02 & 0.00 & 0.1 & 0.0 & 0.0 & 0.0 \\
\hline & & & & & & & & \\
\hline Native\#3 & $\mathrm{A}$ & 6.25 & 0.07 & 0.33 & 9.8 & 1.9 & 0.0 & 0.3 \\
\hline & $\mathrm{BA}$ & 1.90 & 0.04 & 0.01 & 2.1 & 0.6 & 0.0 & 0.2 \\
\hline & $\mathrm{Bw} 1$ & 0.40 & 0.02 & 0.00 & 0.5 & 0.4 & 0.0 & 0.1 \\
\hline & $\mathrm{Bw} 2$ & 0.31 & 0.02 & 0.00 & 0.6 & 0.8 & 0.0 & 0.1 \\
\hline & $\mathrm{BC}$ & 0.27 & 0.02 & 0.00 & 0.7 & 1.0 & 0.0 & 0.1 \\
\hline & $\mathrm{C}$ & 0.26 & 0.04 & 0.00 & 0.9 & 1.3 & 0.0 & 0.1 \\
\hline
\end{tabular}


Table 18. pH, electrical conductivity, Exchangeable P, and Mn of Minesoils and Native Soils.

\begin{tabular}{|c|c|c|c|c|c|}
\hline $\begin{array}{c}\text { Sample } \\
\text { I.D. }\end{array}$ & Horizon & $\mathrm{pH}$ & $\begin{array}{c}\mathrm{EC} \\
\mathrm{dS} / \mathrm{m}\end{array}$ & $\begin{array}{c}\mathrm{P} \\
\mathrm{mg} / \mathrm{L}\end{array}$ & $\begin{array}{c}\mathrm{Mn} \\
\mathrm{mg} / \mathrm{kg}\end{array}$ \\
\hline 23-01 & $\mathrm{A}$ & 4.3 & 0.10 & 6.9 & 37.4 \\
\hline & $\mathrm{AC}$ & 4.5 & 0.05 & 1.2 & 40.7 \\
\hline & $\mathrm{C}$ & 4.6 & 0.03 & 0.3 & 29.4 \\
\hline & & & & & \\
\hline 23-02 & $\mathrm{A}$ & 4.5 & 0.06 & 3.7 & 30.8 \\
\hline & $\mathrm{AC}$ & 4.7 & 0.05 & 2.6 & 31.0 \\
\hline & $\mathrm{C} / \mathrm{B}$ & 4.7 & 0.03 & 9.3 & 5.0 \\
\hline & $\mathrm{C}$ & 5.0 & 0.02 & 4.9 & 5.0 \\
\hline & & & & & \\
\hline $23-03$ & $\mathrm{~A}$ & 5.1 & 0.20 & 6.7 & 43.1 \\
\hline & $\mathrm{AC}$ & 5.2 & 0.13 & 7.0 & 19.3 \\
\hline & $\mathrm{C} 1$ & 4.1 & 0.35 & 0.6 & 21.8 \\
\hline & $\mathrm{C} 2$ & 4.2 & 0.20 & 2.4 & 37.1 \\
\hline & & & & & \\
\hline $23-04$ & $\mathrm{~A}$ & 4.1 & 0.11 & 13.1 & 48.8 \\
\hline & $\mathrm{AC}$ & 4.7 & 0.04 & 4.5 & 21.9 \\
\hline & $\mathrm{C}$ & 5.2 & 0.02 & 4.6 & 5.6 \\
\hline & $\mathrm{C} / \mathrm{B}$ & 5.2 & 0.02 & 4.1 & 16.2 \\
\hline & & & & & \\
\hline $23-05$ & $\mathrm{~A}$ & 5.1 & 0.08 & 8.1 & 14.4 \\
\hline & $\mathrm{AC}$ & 5.4 & 0.05 & 4.5 & 6.2 \\
\hline & $\mathrm{C} 1$ & 6.7 & 0.08 & 1.7 & 0.1 \\
\hline & & & & & \\
\hline $23-06$ & $\mathrm{~A}$ & 4.5 & 0.11 & 9.9 & 36.0 \\
\hline & $\mathrm{Bw}$ & 4.7 & 0.07 & 6.1 & 34.0 \\
\hline & $\mathrm{C}$ & 5.6 & 0.05 & 4.2 & 12.3 \\
\hline
\end{tabular}




\begin{tabular}{|c|c|c|c|c|c|}
\hline $\begin{array}{c}\text { Sample } \\
\text { I.D. }\end{array}$ & Horizon & $\mathrm{pH}$ & $\begin{array}{c}\mathrm{EC} \\
\mathrm{dS} / \mathrm{m}\end{array}$ & $\begin{array}{c}\mathrm{P} \\
\mathrm{mg} / \mathrm{L}\end{array}$ & $\begin{array}{c}\mathrm{Mn} \\
\mathrm{mg} / \mathrm{kg}\end{array}$ \\
\hline \multirow[t]{4}{*}{ 11-01 } & $A$ & 5.0 & 0.16 & 22.3 & 12.1 \\
\hline & $A C$ & 6.0 & 0.06 & 3.2 & 8.7 \\
\hline & C1 & 6.4 & 0.05 & 1.6 & 9.3 \\
\hline & C2 & 6.4 & 0.10 & 1.5 & 0.0 \\
\hline \multirow[t]{4}{*}{$11-02$} & $A$ & 4.8 & 0.08 & 8.9 & 10.4 \\
\hline & $A C$ & 4.8 & 0.04 & 1.3 & 10.1 \\
\hline & C1 & 5.3 & 0.05 & 7.6 & 3.6 \\
\hline & $\mathrm{C} 2$ & 6.0 & 0.06 & 2.6 & 1.8 \\
\hline \multirow[t]{5}{*}{ 11-03 } & $A$ & 5.4 & 0.28 & 8.9 & 6.4 \\
\hline & $A C$ & 6.5 & 0.13 & 0.0 & 0.0 \\
\hline & $\mathrm{C} 1$ & 6.7 & 0.11 & 0.0 & 0.0 \\
\hline & $\mathrm{C} 2$ & 6.6 & 0.10 & 0.9 & 0.0 \\
\hline & $\mathrm{C} 3$ & 6.1 & 0.14 & 1.4 & 2.8 \\
\hline \multirow[t]{5}{*}{ 11-04 } & $A$ & 5.3 & 0.09 & 22.0 & 7.4 \\
\hline & C1 & 5.4 & 0.03 & 8.6 & 1.6 \\
\hline & C2 & 4.9 & 0.06 & 0.9 & 7.7 \\
\hline & $\mathrm{C3}$ & 4.8 & 0.07 & 1.0 & 16.7 \\
\hline & $\mathrm{C} 4$ & 4.9 & 0.05 & 0.5 & 19.5 \\
\hline \multirow[t]{5}{*}{ 11-05 } & $A$ & 6.1 & 0.10 & 1.0 & 0.0 \\
\hline & C1 & 6.5 & 0.09 & 0.6 & 0.0 \\
\hline & C2 & 6.8 & 0.12 & 0.0 & 0.0 \\
\hline & $\mathrm{C3}$ & 6.8 & 0.10 & 0.8 & 0.0 \\
\hline & C4 & 6.8 & 0.15 & 0.0 & 0.0 \\
\hline \multirow[t]{4}{*}{ 11-06 } & A & 5.3 & 0.06 & 6.6 & 16.8 \\
\hline & $A c$ & 5.3 & 0.05 & 2.2 & 13.1 \\
\hline & CB & 5.4 & 0.06 & 2.7 & 7.8 \\
\hline & $C$ & 5.5 & 0.09 & 1.0 & 6.9 \\
\hline
\end{tabular}




\begin{tabular}{|c|c|c|c|c|c|}
\hline $\begin{array}{c}\text { Sample } \\
\text { I.D. }\end{array}$ & Horizon & $\mathrm{pH}$ & $\begin{array}{c}\mathrm{EC} \\
\mathrm{dS} / \mathrm{m}\end{array}$ & $\begin{array}{c}\mathrm{P} \\
\mathrm{mg} / \mathrm{L}\end{array}$ & $\begin{array}{c}\mathrm{Mn} \\
\mathrm{mg} / \mathrm{kg}\end{array}$ \\
\hline \multirow[t]{4}{*}{$7-01$} & $\bar{A}$ & 6.1 & 0.15 & 2.8 & 4.6 \\
\hline & C1/B & 6.5 & 0.11 & 1.2 & 2.9 \\
\hline & C2/B & 6.8 & 0.06 & 1.0 & 0.0 \\
\hline & $\mathrm{C}$ & 7.0 & 0.05 & 2.9 & 0.0 \\
\hline \multirow[t]{5}{*}{$7-02$} & A & 6.0 & 0.11 & 9.2 & 7.9 \\
\hline & $\mathrm{AC}$ & 6.0 & 0.07 & 1.4 & 8.5 \\
\hline & $\mathrm{C} 1 / \mathrm{B}$ & 6.7 & 0.05 & 1.4 & 0.0 \\
\hline & C2/B & 6.4 & 0.05 & 1.9 & 4.4 \\
\hline & $\mathrm{C}$ & 6.7 & 0.1 & 1.1 & $\overline{0.0}$ \\
\hline \multirow[t]{6}{*}{$7-03$} & $\mathrm{~A}$ & 5.0 & 0.08 & 3.6 & 13.0 \\
\hline & $A C$ & 4.7 & 0.105 & 0.0 & 27.0 \\
\hline & $\mathrm{C} / \mathrm{B}$ & 5.5 & 0.055 & 1.2 & 12.1 \\
\hline & C1 & 6.1 & 0.05 & 1.2 & 4.2 \\
\hline & C2 & 6.4 & 0.06 & 1.1 & 0.0 \\
\hline & C3 & 6.7 & 0.07 & 2.7 & 0.0 \\
\hline \multirow[t]{5}{*}{$7-04$} & $A$ & 4.3 & 0.06 & 29.1 & 12.4 \\
\hline & $\mathrm{Bw}$ & 4.1 & 0.07 & 5.3 & 8.2 \\
\hline & C1 & 4.2 & 0.04 & 4.1 & 3.7 \\
\hline & C2 & 4.1 & 0.05 & 3.5 & 2.3 \\
\hline & C3 & 4.2 & 0.05 & 3.4 & 15.2 \\
\hline \multirow[t]{4}{*}{$7-05$} & $A$ & 5.1 & 0.145 & 9.6 & 11.2 \\
\hline & AC & 5.7 & 0.12 & 0.0 & 5.5 \\
\hline & $\mathrm{C} 1 / \mathrm{B}$ & 5.0 & 0.08 & 0.0 & 8.8 \\
\hline & $\mathrm{C} 2 / \mathrm{B}$ & 5.1 & 0.09 & 0.5 & 10.5 \\
\hline \multirow[t]{5}{*}{$7-06$} & A1 & 4.2 & 0.09 & 26.7 & 6.4 \\
\hline & A2 & 4.2 & 0.05 & 6.9 & 5.2 \\
\hline & $\overline{A C}$ & 4.2 & 0.07 & 26.2 & 6.5 \\
\hline & $\mathrm{C} 1$ & 4.4 & 0.03 & 4.5 & 14.1 \\
\hline & C2 & 4.4 & 0.04 & 0.7 & 30.0 \\
\hline
\end{tabular}




\begin{tabular}{|c|c|c|c|c|c|}
\hline $\begin{array}{c}\text { Sample } \\
\text { I.D. }\end{array}$ & Horizon & $\mathrm{pH}$ & $\begin{array}{c}\mathrm{EC} \\
\mathrm{dS} / \mathrm{m}\end{array}$ & $\begin{array}{c}\mathrm{P} \\
\mathrm{mg} / \mathrm{L}\end{array}$ & $\begin{array}{c}\mathrm{Mn} \\
\mathrm{mg} / \mathrm{kg}\end{array}$ \\
\hline \multirow[t]{5}{*}{$2-01$} & $\bar{A}$ & 5.0 & 0.07 & 82.7 & 16.7 \\
\hline & $\mathrm{AC}$ & 5.0 & 0.07 & 37.4 & 16.6 \\
\hline & $\mathrm{C} 1$ & 5.1 & 0.11 & 4.9 & 13.2 \\
\hline & $\mathrm{C} 2$ & 5.2 & 0.12 & 6.8 & 19.0 \\
\hline & C3 & 5.3 & 0.06 & 1.7 & 5.9 \\
\hline \multirow[t]{4}{*}{$2-02$} & $\mathrm{~A}$ & 5.8 & 0.18 & 45.7 & 11.9 \\
\hline & $\mathrm{C} 1$ & 6.6 & 0.12 & 7.1 & 2.7 \\
\hline & $\mathrm{C} 2$ & 4.8 & 0.63 & 3.1 & 52.2 \\
\hline & C3 & 5.7 & 0.19 & 5.9 & 9.6 \\
\hline \multirow[t]{4}{*}{$2-03$} & $\bar{A}$ & 5.8 & 0.12 & 66.0 & 8.8 \\
\hline & $\mathrm{AC}$ & 6.4 & 0.14 & 37.2 & 4.0 \\
\hline & $\mathrm{C} 1$ & 5.3 & 0.31 & 2.4 & 17.5 \\
\hline & $\mathrm{C} 2$ & 4.7 & 0.10 & 1.2 & 17.2 \\
\hline \multirow[t]{4}{*}{$2-04$} & $\mathrm{~A}$ & 6.4 & 0.14 & 49.7 & 6.9 \\
\hline & $\mathrm{C} 1$ & 5.7 & 0.12 & 4.0 & 27.7 \\
\hline & $\mathrm{C} 2$ & 6.1 & 0.25 & 3.1 & 14.8 \\
\hline & $\mathrm{C} 3$ & 6.1 & 0.12 & 2.2 & 7.6 \\
\hline \multirow[t]{3}{*}{$2-05$} & A & 5.5 & 0.13 & 157.8 & 33.0 \\
\hline & $\overline{\mathrm{AC}}$ & 6.1 & 0.09 & 28.1 & 10.0 \\
\hline & $\bar{C}$ & 5.9 & 0.54 & 1.7 & 7.0 \\
\hline \multirow[t]{4}{*}{$2-06$} & $\bar{A}$ & 6.0 & 0.14 & 14.6 & 22.5 \\
\hline & $\overline{\mathrm{AC}}$ & 5.8 & 0.10 & 8.2 & 27.0 \\
\hline & $\mathrm{C} / \mathrm{B}$ & 5.8 & 0.07 & 3.3 & 22.8 \\
\hline & $\mathrm{C}$ & 5.8 & 0.09 & 2.9 & 15.5 \\
\hline
\end{tabular}




\begin{tabular}{|c|c|c|c|c|c|}
\hline $\begin{array}{c}\text { Sample } \\
\text { I.D. }\end{array}$ & Horizon & $\mathrm{pH}$ & $\begin{array}{c}\mathrm{EC} \\
\mathrm{dS} / \mathrm{m}\end{array}$ & $\begin{array}{c}\mathrm{P} \\
\mathrm{mg} / \mathrm{L}\end{array}$ & $\begin{array}{c}\mathrm{Mn} \\
\mathrm{mg} / \mathrm{kg}\end{array}$ \\
\hline Native\#1 & $\mathrm{A}$ & 4.7 & 0.30 & 33.3 & 153.8 \\
\hline & $\mathrm{BA}$ & 4.5 & 0.10 & 12.2 & 70.7 \\
\hline & $\mathrm{Bw} 1$ & 4.4 & 0.07 & 4.3 & 27.8 \\
\hline & $\mathrm{Bw} 2$ & 4.6 & 0.05 & 0.6 & 28.7 \\
\hline & & & & & \\
\hline Native\#2 & $\mathrm{A} / \mathrm{E}$ & 3.7 & 0.22 & 32.7 & 26.9 \\
\hline & $\mathrm{BA}$ & 4.6 & 0.04 & 3.8 & 2.1 \\
\hline & $\mathrm{Bw}$ & 4.5 & 0.05 & 1.9 & 2.1 \\
\hline & $\mathrm{BC}$ & 4.5 & 0.05 & 3.1 & 2.1 \\
\hline & & & & & \\
\hline Native\#3 & $\mathrm{A}$ & 6.3 & 0.14 & 8.2 & 26.5 \\
\hline & $\mathrm{BA}$ & 5.1 & 0.03 & 2.3 & 32.6 \\
\hline & $\mathrm{Bw} 1$ & 4.9 & 0.02 & 0.1 & 6.2 \\
\hline & $\mathrm{Bw} 2$ & 4.9 & 0.02 & 0.1 & 6.0 \\
\hline & $\mathrm{BC}$ & 5.0 & 0.02 & 0.3 & 6.4 \\
\hline & $\mathrm{C}$ & 5.1 & 0.02 & 0.7 & 6.6 \\
\hline
\end{tabular}


Table 19. Dicitrate bicarbonate extractable $\mathrm{Fe}, \mathrm{Al}$, and $\mathrm{P}$

\begin{tabular}{|c|c|c|c|c|}
\hline $\begin{array}{c}\text { Sample } \\
\text { I.D. }\end{array}$ & Horizon & $\begin{array}{c}\mathrm{Fe} \\
(\mathrm{mg} / \mathrm{kg})\end{array}$ & $\begin{array}{c}\mathrm{Al} \\
(\mathrm{mg} / \mathrm{kg})\end{array}$ & $\begin{array}{c}\mathrm{P} \\
(\mathrm{mg} / \mathrm{kg})\end{array}$ \\
\hline $23-01$ & $\mathrm{~A}$ & 10173.02 & 2355.58 & 117.91 \\
\hline & $\mathrm{AC}$ & 11963.10 & 2568.97 & 78.59 \\
\hline & $\mathrm{C}$ & 11830.27 & 2849.40 & 66.85 \\
\hline $23-02$ & $\mathrm{~A}$ & 8700.87 & 1202.71 & 81.09 \\
\hline & $\mathrm{AC}$ & 8007.03 & 971.72 & 59.17 \\
\hline & $\mathrm{C} / \mathrm{B}$ & 2350.39 & 237.45 & 51.04 \\
\hline $23-03$ & $\mathrm{~A}$ & 11188.64 & 1160.21 & 126.91 \\
\hline & $\mathrm{AC}$ & 9719.37 & 816.81 & 88.46 \\
\hline & $\mathrm{C} 1$ & 6788.45 & 510.89 & 37.40 \\
\hline $23-04$ & $\mathrm{~A}$ & 9828.55 & 741.67 & 129.99 \\
\hline & $\mathrm{AC}$ & 11016.27 & 686.52 & 93.63 \\
\hline & $\mathrm{C}$ & 8113.43 & 344.97 & 71.79 \\
\hline $23-05$ & $\mathrm{~A}$ & 6449.25 & 438.27 & 87.31 \\
\hline & $\mathrm{AC}$ & 7813.55 & 605.24 & 64.26 \\
\hline & $\mathrm{C} 1$ & 7515.89 & 564.18 & 35.50 \\
\hline $23-06$ & $\mathrm{~A}$ & 9692.83 & 1063.23 & 124.39 \\
\hline & $\mathrm{B} w$ & 10152.35 & 1208.29 & 92.17 \\
\hline & $\mathrm{C}$ & 10633.89 & 1001.94 & 72.82 \\
\hline
\end{tabular}

\begin{tabular}{|c|c|c|c|c|}
\hline $11-01$ & A & 7439.54 & 537.67 & 113.54 \\
\hline & AC & 7071.36 & 536.73 & 47.36 \\
\hline & C1 & 7449.53 & 398.60 & 32.49 \\
\hline $11-02$ & A & 7384.70 & 1354.13 & 90.76 \\
\hline & AC & 7852.62 & 1465.48 & 50.79 \\
\hline & C1 & 9750.69 & 632.63 & 80.70 \\
\hline $11-03$ & A & 5851.61 & 490.17 & 68.24 \\
\hline & AC & 6186.74 & 252.97 & 15.80 \\
\hline & C1 & 5603.51 & 170.62 & 0.50 \\
\hline $11-04$ & A & 6153.98 & 396.66 & 99.12 \\
\hline & C1 & 6615.38 & 448.12 & 65.60 \\
\hline & C2 & 9604.96 & 1465.27 & 63.04 \\
\hline $11-05$ & A & 5751.12 & 341.03 & 17.57 \\
\hline & C1 & 7026.99 & 554.22 & 16.27 \\
\hline & C2 & 5161.01 & 332.68 & 12.85 \\
\hline $11-06$ & A & 7179.85 & 1489.05 & 89.71 \\
\hline & AC & 7737.32 & 1782.31 & 68.41 \\
\hline & CB & 8565.03 & 798.31 & 59.25 \\
\hline & & & & \\
\hline
\end{tabular}




\begin{tabular}{|c|c|c|c|c|}
\hline $\begin{array}{c}\text { Sample } \\
\text { I.D. }\end{array}$ & Horizon & $\begin{array}{c}\text { Fe } \\
(\mathrm{mg} / \mathrm{kg})\end{array}$ & $\begin{array}{c}\text { Al } \\
(\mathrm{mg} / \mathrm{kg})\end{array}$ & $\begin{array}{c}\mathrm{P} \\
(\mathrm{mg} / \mathrm{kg})\end{array}$ \\
\hline $7-01$ & $\mathrm{~A}$ & 10174.75 & 283.94 & 44.93 \\
\hline & $\mathrm{C} 1 / \mathrm{B}$ & 10398.28 & 308.12 & 26.76 \\
\hline & C2/B & 11711.88 & 325.50 & 37.84 \\
\hline $7-02$ & $\mathrm{~A}$ & 5247.50 & 362.32 & 64.80 \\
\hline & AC & 5758.48 & 513.54 & 43.09 \\
\hline & C1/B & 5555.97 & 457.52 & 37.63 \\
\hline $7-03$ & $\mathrm{~A}$ & 5662.07 & 1786.04 & 40.58 \\
\hline & AC & 6457.38 & 624.51 & 38.50 \\
\hline & C/B & 5642.54 & 397.01 & 31.29 \\
\hline $7-04$ & A & 5828.85 & 1155.80 & 120.05 \\
\hline & Bw & 5019.49 & 1381.30 & 47.72 \\
\hline & C1 & 3525.66 & 313.47 & 37.40 \\
\hline $7-05$ & A & 4944.43 & 352.76 & 51.43 \\
\hline & AC & 5503.54 & 308.57 & 14.97 \\
\hline & C1/B & 4623.20 & 316.99 & 25.62 \\
\hline $7-06$ & A1 & 6022.53 & 469.46 & 150.76 \\
\hline & A2 & 5892.61 & 481.25 & 54.50 \\
\hline & AC & 8671.23 & 635.84 & 68.18 \\
\hline & C1 & 6143.54 & 471.34 & 119.59 \\
\hline
\end{tabular}

\begin{tabular}{|c|c|c|c|c|}
\hline $2-01$ & A & 6359.78 & 781.89 & 178.82 \\
\hline & AC & 7455.29 & 1022.55 & 129.50 \\
\hline & C1 & 7762.28 & 2056.86 & 53.69 \\
\hline $2-02$ & A & 9333.94 & 593.06 & 162.65 \\
\hline & C1 & 8788.54 & 578.25 & 61.03 \\
\hline & C2 & 10404.32 & 2158.27 & 69.29 \\
\hline $2-03$ & A & 6264.54 & 777.93 & 137.89 \\
\hline & AC & 6860.65 & 1206.74 & 101.75 \\
\hline & C1 & 6162.99 & 1085.29 & 30.74 \\
\hline $2-04$ & A & 5229.45 & 608.77 & 189.19 \\
\hline & C1 & 7633.56 & 2540.97 & 74.71 \\
\hline & C2 & 8757.92 & 1778.14 & 76.32 \\
\hline $2-05$ & A & 6645.69 & 1116.95 & 303.88 \\
\hline & AC & 8545.99 & 915.47 & 121.02 \\
\hline & C & 6938.62 & 798.90 & 54.98 \\
\hline $2-06$ & A & 8950.27 & 754.89 & 126.19 \\
\hline & AC & 9119.60 & 753.16 & 89.10 \\
\hline & C/B & 8478.87 & 628.01 & 78.27 \\
\hline & & & & \\
\hline
\end{tabular}




\begin{tabular}{|c|c|c|c|c|}
\hline $\begin{array}{c}\text { Sample } \\
\text { I.D. }\end{array}$ & Horizon & $\begin{array}{c}\mathrm{Fe} \\
(\mathrm{mg} / \mathrm{kg})\end{array}$ & $\begin{array}{c}\mathrm{Al} \\
(\mathrm{mg} / \mathrm{kg})\end{array}$ & $\begin{array}{c}\mathrm{P} \\
(\mathrm{mg} / \mathrm{kg})\end{array}$ \\
\hline Native\#1 & $\mathrm{A}$ & 7567.37 & 2679.56 & 255.30 \\
\hline & $\mathrm{BA}$ & 5902.89 & 2723.27 & 149.92 \\
\hline & $\mathrm{Bw} 1$ & 9702.00 & 2081.66 & 109.48 \\
\hline Native\#2 & $\mathrm{A} / \mathrm{E}$ & 3125.60 & 1080.43 & 142.69 \\
\hline & $\mathrm{BA}$ & 4292.61 & 1438.09 & 58.97 \\
\hline & $\mathrm{Bw}$ & 10269.19 & 1625.70 & 100.34 \\
\hline Native\#3 & $\mathrm{A}$ & 11730.58 & 3265.92 & 205.02 \\
\hline & $\mathrm{BA}$ & 7933.82 & 3441.43 & 128.22 \\
\hline & $\mathrm{Bw} 1$ & 11093.44 & 3485.57 & 63.60 \\
\hline
\end{tabular}


Appendix D

Productivity Index Sufficiency Values 
Table 20. Productivity, sufficiency, and corrected weighting factor values (unitless) for the productivity index.

\begin{tabular}{|c|c|c|c|c|c|c|c|c|c|c|}
\hline Sample \# & Horizon & Depth & $\begin{array}{c}\text { Depth } \\
(\mathrm{cm})\end{array}$ & $\mathrm{pH}^{*}$ & $\mathrm{EC}^{*}$ & B.D. $^{*}$ & $\mathrm{P}^{*}$ & Slope $^{*}$ & $\begin{array}{c}\text { Weighting } \\
\text { Factor }\end{array}$ & $\begin{array}{c}\text { P.I. } \\
(\%)\end{array}$ \\
\hline $23-01$ & $\mathrm{~A}$ & $3-7$ & 7 & 0.82 & 1.00 & 1.00 & 0.80 & 0.63 & 0.25 & 0.49 \\
\hline & $\mathrm{AC}$ & $7-22$ & 22 & 0.87 & 1.00 & 0.92 & 0.67 & & 0.34 & \\
\hline & $\mathrm{C}$ & $22-65$ & 65 & 0.89 & 1.00 & 0.60 & 0.64 & & 0.34 & \\
\hline $23-02$ & $\mathrm{~A}$ & $6-13$ & 13 & 0.87 & 1.00 & 1.00 & 0.74 & 1.00 & 0.41 & 0.85 \\
\hline & $\mathrm{B}$ & $13-31$ & 31 & 0.91 & 1.00 & 0.92 & 0.71 & & 0.31 & \\
\hline & $\mathrm{C} / \mathrm{B}$ & $37-75$ & 75 & 0.93 & 1.00 & 0.49 & 0.85 & & 0.24 & \\
\hline & $\mathrm{C}$ & $75-105+$ & 100 & 1.00 & 1.00 & 0.49 & 0.76 & & 0.03 & \\
\hline $23-03$ & $\mathrm{~A}$ & $5-12$ & 12 & 1.00 & 1.00 & 1.00 & 0.80 & 0.68 & 0.39 & 0.59 \\
\hline & $\mathrm{AC}$ & $12-30$ & 30 & 1.00 & 1.00 & 0.81 & 0.81 & & 0.32 & \\
\hline & $\mathrm{C} 1$ & $30-87$ & 87 & 0.77 & 1.00 & 0.88 & 0.65 & & 0.27 & \\
\hline & $\mathrm{C} 2$ & $87-115+$ & 100 & 0.81 & 1.00 & 0.18 & 0.70 & & 0.01 & \\
\hline $23-04$ & $\mathrm{~A}$ & $4-12$ & 12 & 0.78 & 1.00 & 1.00 & 0.91 & 1.00 & 0.39 & 0.87 \\
\hline & $\mathrm{AC}$ & $12-38$ & 38 & 0.93 & 1.00 & 0.73 & 0.75 & & 0.40 & \\
\hline & $\mathrm{C}$ & $38-69$ & 69 & 1.00 & 1.00 & 0.96 & 0.76 & & 0.15 & \\
\hline & $\mathrm{C} / \mathrm{B}$ & $69-150+$ & 100 & 1.00 & 1.00 & 0.97 & 0.75 & & 0.04 & \\
\hline $23-05$ & $\mathrm{~A}$ & $3-8$ & 8 & 1.00 & 1.00 & 1.00 & 0.83 & 0.65 & 0.28 & 0.28 \\
\hline & $\mathrm{AC}$ & $8-26$ & 26 & 1.00 & 1.00 & 0.04 & 0.75 & & 0.37 & \\
\hline & $\mathrm{C} 1$ & $26-61$ & 61 & 0.83 & 1.00 & 0.00 & 0.69 & & 0.26 & \\
\hline $23-06$ & $\mathrm{~A}$ & $5-11$ & 11 & 0.87 & 1.00 & 1.00 & 0.86 & 0.90 & 0.36 & 0.66 \\
\hline & $\mathrm{Bw}$ & $11-26$ & 26 & 0.92 & 1.00 & 0.27 & 0.79 & & 0.29 & \\
\hline & $\mathrm{C}$ & $26-120+$ & 100 & 1.00 & 1.00 & 0.19 & 0.75 & & 0.33 & \\
\hline
\end{tabular}




\begin{tabular}{|c|c|c|c|c|c|c|c|c|c|c|}
\hline Sample \# & Horizon & Depth & $\begin{array}{c}\text { Depth } \\
\text { (cm) }\end{array}$ & $\mathrm{pH}$ & EC & B.D. & $P$ & Slope & $\begin{array}{c}\text { Weighting } \\
\text { Factor }\end{array}$ & $\begin{array}{l}\text { P.I. } \\
(\%)\end{array}$ \\
\hline \multirow[t]{4}{*}{ 11-01 } & $A$ & $3-11$ & 11 & 1.00 & 1.00 & 1.00 & 1.00 & 0.61 & 0.36 & 0.29 \\
\hline & $A C$ & $11-37$ & 37 & 1.00 & 1.00 & 0.07 & 0.72 & & 0.42 & \\
\hline & C1 & $37-89$ & 89 & 0.90 & 1.00 & 0.73 & 0.68 & & 0.19 & \\
\hline & $\mathrm{C} 2$ & $89-160+$ & 100 & 0.90 & 1.00 & 1.00 & 0.68 & & 0.01 & \\
\hline \multirow[t]{4}{*}{$11-02$} & $A$ & $3-12$ & 12 & 0.94 & 1.00 & 1.00 & 0.84 & 1.00 & 0.39 & 0.51 \\
\hline & $A C$ & $12-41$ & 41 & 0.95 & 1.00 & 0.51 & 0.67 & & 0.42 & \\
\hline & C1 & $41-75$ & 75 & 1.00 & 1.00 & 0.49 & 0.82 & & 0.14 & \\
\hline & $\mathrm{C} 2$ & $75-125+$ & 100 & 1.00 & 1.00 & 0.49 & 0.71 & & 0.03 & \\
\hline \multirow[t]{5}{*}{ 11-03 } & $A$ & $0-3$ & 3 & 1.00 & 1.00 & 1.00 & 0.84 & 0.69 & 0.12 & 0.35 \\
\hline & $A C$ & $3-16$ & 16 & 0.87 & 1.00 & 1.00 & 0.63 & & 0.36 & \\
\hline & C1 & $16-49$ & 49 & 0.84 & 1.00 & 0.86 & 0.63 & & 0.39 & \\
\hline & $\mathrm{C} 2$ & $49-91$ & 91 & 0.84 & 1.00 & 0.47 & 0.66 & & 0.11 & \\
\hline & C3 & $91-125$ & 100 & 0.96 & 1.00 & 0.60 & 0.68 & & 0.01 & \\
\hline \multirow[t]{4}{*}{$11-04$} & $A$ & $2-8$ & 8 & 1.00 & 1.00 & 1.00 & 1.00 & 1.00 & 0.28 & 0.48 \\
\hline & C1 & $8-24$ & 24 & 1.00 & 1.00 & 0.69 & 0.84 & & 0.34 & \\
\hline & $\mathrm{C} 2$ & $24-59$ & 59 & 0.98 & 1.00 & 0.00 & 0.66 & & 0.29 & \\
\hline & C3 & $59-114$ & 100 & 0.95 & 1.00 & 0.00 & 0.67 & & 0.07 & \\
\hline \multirow[t]{5}{*}{$11-05$} & $A$ & $0-9$ & 9 & 0.98 & 1.00 & 1.00 & 0.66 & 0.70 & 0.31 & 0.25 \\
\hline & C1 & $9-22$ & 22 & 0.88 & 1.00 & 0.00 & 0.65 & & 0.28 & \\
\hline & $\mathrm{C} 2$ & $22-45$ & 45 & 0.81 & 1.00 & 0.88 & 0.63 & & 0.25 & \\
\hline & C3 & $45-79$ & 79 & 0.81 & 1.00 & 0.49 & 0.66 & & 0.12 & \\
\hline & C4 & 79-135+ & 100 & 0.80 & 1.00 & 0.49 & 0.63 & & 0.02 & \\
\hline \multirow[t]{4}{*}{$11-06$} & $A$ & $0-7$ & 7 & 1.00 & 1.00 & 1.00 & 0.80 & 1.00 & 0.25 & 0.65 \\
\hline & $A C$ & $7-36$ & 36 & 1.00 & 1.00 & 0.93 & 0.70 & & 0.52 & \\
\hline & CB & $36-72$ & 72 & 1.00 & 1.00 & 0.86 & 0.71 & & 0.18 & \\
\hline & $\mathrm{C}$ & $72-150+$ & 100 & 1.00 & 1.00 & 0.25 & 0.66 & & 0.04 & \\
\hline
\end{tabular}




\begin{tabular}{|c|c|c|c|c|c|c|c|c|c|c|}
\hline Sample \# & Horizon & Depth & $\begin{array}{c}\text { Depth } \\
(\mathrm{cm})\end{array}$ & $\mathrm{pH}$ & $\mathrm{EC}$ & $\mathrm{B} . \mathrm{D}$. & $\mathrm{P}$ & Slope & $\begin{array}{c}\text { Weighting } \\
\text { Factor }\end{array}$ & $\begin{array}{c}\text { P.I. } \\
(\%)\end{array}$ \\
\hline $7-01$ & $\mathrm{~A}$ & $0-8$ & 8 & 0.97 & 1.00 & 1.00 & 0.71 & 0.61 & 0.28 & 0.33 \\
\hline & C1/B & $8-30$ & 30 & 0.88 & 1.00 & 0.92 & 0.67 & & 0.43 & \\
\hline & C2/B & $30-77$ & 77 & 0.79 & 1.00 & 0.87 & 0.66 & & 0.25 & \\
\hline & C & $77-125+$ & 100 & 0.76 & 1.00 & 0.87 & 0.72 & & 0.03 & \\
\hline $7-02$ & A & $2-8$ & 8 & 1.00 & 1.00 & 1.00 & 0.85 & 0.95 & 0.28 & 0.61 \\
\hline & AC & $8-24$ & 24 & 1.00 & 1.00 & 0.99 & 0.68 & & 0.34 & \\
\hline & C1/B & $24-60$ & 60 & 0.83 & 1.00 & 0.83 & 0.68 & & 0.29 & \\
\hline & C2/B & $60-107$ & 100 & 0.90 & 1.00 & 0.99 & 0.69 & & 0.07 & \\
\hline $7-03$ & A & $2-6$ & 6 & 0.99 & 1.00 & 1.00 & 0.73 & 0.61 & 0.22 & 0.34 \\
\hline & AC & $6-28$ & 28 & 0.92 & 1.00 & 0.84 & 0.63 & & 0.46 & \\
\hline & C/B & $24-48$ & 48 & 1.00 & 1.00 & 0.89 & 0.67 & & 0.18 & \\
\hline & C1 & $48-66$ & 66 & 0.99 & 1.00 & 0.87 & 0.67 & & 0.07 & \\
\hline & C2 & $66-97$ & 97 & 0.90 & 1.00 & 0.87 & 0.67 & & 0.05 & \\
\hline & C3 & $97-160+$ & 100 & 0.83 & 1.00 & 0.87 & 0.71 & & 0.00 & \\
\hline $7-04$ & A & $0-7$ & 7 & 0.82 & 1.00 & 1.00 & 1.00 & 1.00 & 0.25 & 0.55 \\
\hline & Bw & $7-21$ & 21 & 0.77 & 1.00 & 0.92 & 0.77 & & 0.33 & \\
\hline & C1 & $21-42$ & 42 & 0.79 & 1.00 & 0.63 & 0.75 & & 0.24 & \\
\hline & C2 & $42-101$ & 100 & 0.77 & 1.00 & 0.86 & 0.73 & & 0.16 & \\
\hline A & $2-7$ & 7 & 1.00 & 1.00 & 1.00 & 0.85 & 0.61 & 0.25 & 0.41 \\
\hline & AC & $7-37$ & 37 & 1.00 & 1.00 & 0.95 & 0.63 & & 0.53 & \\
\hline & C1/B & $37-92$ & 92 & 1.00 & 1.00 & 1.00 & 0.63 & & 0.20 & \\
\hline & C2/B & $92-140+$ & 100 & 1.00 & 1.00 & 1.00 & 0.65 & & 0.01 & \\
\hline & A1 & $0-10$ & 10 & 0.81 & 1.00 & 1.00 & 1.00 & 1.00 & 0.34 & 0.70 \\
\hline & A2 & $10-19$ & 19 & 0.80 & 1.00 & 1.00 & 0.80 & & 0.20 & \\
\hline & AC & $19-32$ & 32 & 0.80 & 1.00 & 0.96 & 1.00 & & 0.19 & \\
\hline & C1 & $32-73$ & 73 & 0.85 & 1.00 & 1.00 & 0.76 & & 0.22 & \\
\hline & C2 & $73-110+$ & 100 & 0.84 & 1.00 & 0.33 & 0.65 & & 0.03 & \\
\hline
\end{tabular}




\begin{tabular}{|c|c|c|c|c|c|c|c|c|c|c|}
\hline Sample \# & Horizon & Depth & $\begin{array}{c}\text { Depth } \\
\text { (cm) }\end{array}$ & $\mathrm{pH}$ & EC & B.D. & $P$ & Slope & $\begin{array}{c}\text { Weighting } \\
\text { Factor }\end{array}$ & $\begin{array}{l}\text { P.I. } \\
(\%)\end{array}$ \\
\hline \multirow[t]{5}{*}{$2-01$} & $\mathrm{~A}$ & $1-4$ & 4 & 1.00 & 1.00 & 1.00 & 1.00 & 0.80 & 0.15 & 0.62 \\
\hline & $A C$ & $4-10$ & 10 & 1.00 & 1.00 & 0.73 & 1.00 & & 0.19 & \\
\hline & $\mathrm{C} 1$ & $10-41$ & 41 & 1.00 & 1.00 & 1.00 & 0.76 & & 0.48 & \\
\hline & $\mathrm{C} 2$ & $41-92$ & 92 & 1.00 & 1.00 & 1.00 & 0.80 & & 0.16 & \\
\hline & C3 & $92-150+$ & 100 & 1.00 & 1.00 & 0.63 & 0.68 & & 0.01 & \\
\hline \multirow[t]{3}{*}{$2-02$} & $A$ & $2-6$ & 6 & 1.00 & 1.00 & 1.00 & 1.00 & 1.00 & 0.22 & 0.71 \\
\hline & C1 & $6-51$ & 51 & 0.86 & 1.00 & 0.94 & 0.81 & & 0.66 & \\
\hline & $\mathrm{C} 2$ & $51-104$ & 100 & 0.95 & 0.91 & 0.86 & 0.72 & & 0.11 & \\
\hline \multirow[t]{4}{*}{$2-03$} & $A$ & $1-7$ & 7 & 1.00 & 1.00 & 1.00 & 1.00 & 0.73 & 0.25 & 0.53 \\
\hline & $A C$ & $7-13$ & 13 & 0.90 & 1.00 & 0.89 & 1.00 & & 0.16 & \\
\hline & C1 & $13-56$ & 56 & 1.00 & 1.00 & 1.00 & 0.70 & & 0.49 & \\
\hline & $\mathrm{C} 2$ & $56-82$ & 82 & 0.93 & 1.00 & 0.00 & 0.67 & & 0.07 & \\
\hline \multirow[t]{3}{*}{$2-04$} & $A$ & $1-7$ & 7 & 0.90 & 1.00 & 1.00 & 1.00 & 1.00 & 0.25 & 0.56 \\
\hline & C1 & $7-37$ & 37 & 1.00 & 1.00 & 0.86 & 0.74 & & 0.53 & \\
\hline & $\mathrm{C} 2$ & $37-120$ & 100 & 0.99 & 1.00 & 0.00 & 0.72 & & 0.20 & \\
\hline \multirow[t]{3}{*}{$2-05$} & $A$ & $1-5$ & 5 & 1.00 & 1.00 & 1.00 & 1.00 & 0.61 & 0.18 & 0.23 \\
\hline & $A C$ & $5-22$ & 22 & 0.99 & 1.00 & 0.31 & 1.00 & & 0.41 & \\
\hline & $C$ & $22-64$ & 64 & 1.00 & 0.95 & 0.31 & 0.68 & & 0.33 & \\
\hline \multirow[t]{4}{*}{$2-06$} & $A$ & $2-8$ & 8 & 1.00 & 1.00 & 1.00 & 0.93 & 1.00 & 0.28 & 0.75 \\
\hline & $A C$ & $8-14$ & 14 & 1.00 & 1.00 & 0.88 & 0.83 & & 0.16 & \\
\hline & $\mathrm{C} / \mathrm{B}$ & $14-29$ & 29 & 1.00 & 1.00 & 1.00 & 0.73 & & 0.26 & \\
\hline & $\mathrm{C}$ & $29-120+$ & 100 & 1.00 & 1.00 & 0.90 & 0.72 & & 0.29 & \\
\hline
\end{tabular}




\begin{tabular}{|c|c|c|c|c|c|c|c|c|c|c|}
\hline Sample \# & Horizon & Depth & $\begin{array}{c}\text { Depth } \\
(\mathrm{cm})\end{array}$ & $\mathrm{pH}$ & $\mathrm{EC}$ & $\mathrm{B} . \mathrm{D}$. & $\mathrm{P}$ & Slope & $\begin{array}{c}\text { Weighting } \\
\text { Factor }\end{array}$ & $\begin{array}{c}\text { P.I. } \\
(\%)\end{array}$ \\
\hline Native\#1 & $\mathrm{A}$ & $0-9$ & 9 & 0.94 & 1.00 & 1.00 & 1.00 & 1.00 & 0.31 & 0.70 \\
\hline & $\mathrm{BA}$ & $9-18$ & 18 & 0.87 & 1.00 & 1.00 & 0.89 & & 0.21 & \\
\hline & Bw1 & $18-43$ & 43 & 0.85 & 1.00 & 0.96 & 0.75 & & 0.31 & \\
\hline & Bw2 & $43-67$ & 67 & 0.91 & 1.00 & 0.87 & 0.65 & & 0.11 & \\
\hline Native\#2 & A/E & $2-5$ & 5 & 0.68 & 1.00 & 1.00 & 1.00 & 1.00 & 0.20 & 0.59 \\
\hline & BA & $5-23$ & 23 & 0.89 & 1.00 & 1.00 & 0.74 & & 0.41 & \\
\hline & Bw & $23-59$ & 59 & 0.88 & 1.00 & 0.84 & 0.69 & & 0.30 & \\
\hline & BC & $59-88$ & 88 & 0.87 & 1.00 & 0.73 & 0.72 & & 0.06 & \\
\hline Native\#3 & A & $1-8$ & 8 & 0.92 & 1.00 & 1.00 & 0.83 & 1.00 & 0.27 & 0.61 \\
\hline & BA & $8-15$ & 15 & 1.00 & 1.00 & 1.00 & 0.70 & & 0.19 & \\
\hline & Bw1 & $15-76$ & 76 & 0.98 & 1.00 & 0.83 & 0.64 & & 0.50 & \\
\hline & Bw2 & $76-100$ & 100 & 0.99 & 1.00 & 0.84 & 0.64 & & 0.03 & \\
\hline
\end{tabular}

$* \mathrm{pH}=$ Sufficiency value derived from original data

$\mathrm{EC}=$ Sufficiency value derived from original data

B.D. $=$ Sufficiency value derived from original data

$\mathrm{P}=$ Sufficiency value derived from original data

Slope $=$ Sufficiency value derived from original data 


\section{Vita}

The author was born in Spartanburg, South Carolina in 1976. He completed his B.S. degree in Agronomy at Clemson University in 1999. He then attended West Virginia University and earned a Masters of Science in Plant and Soil Sciences in 2001. He is currently enrolled at West Virginia University pursuing his doctoral degree in Soil Science.

Kevin Thomas 